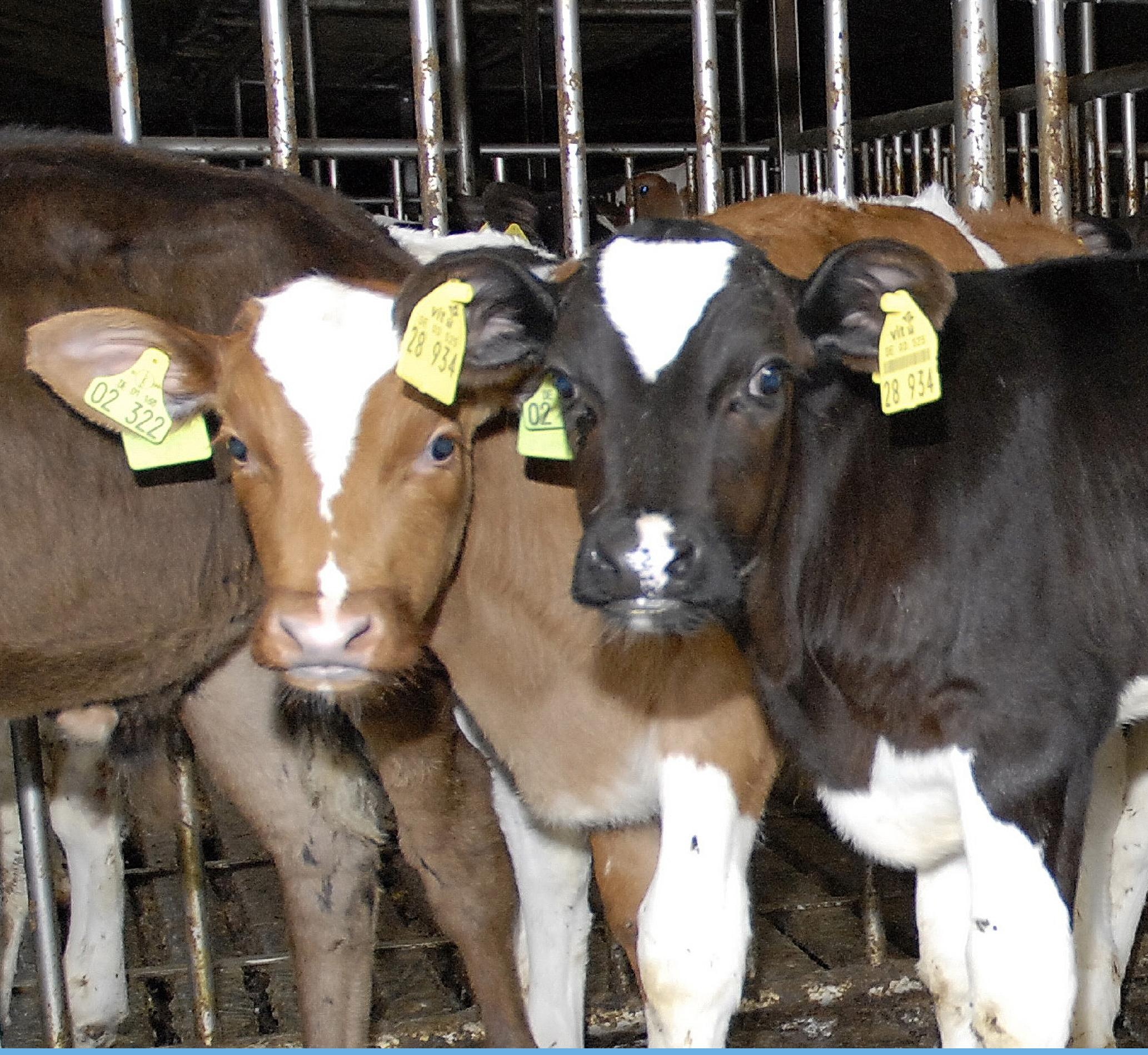

Pilotstudie implementatie welzijnsmonitor vleeskalveren

Kees van Reenen, Maaike Wolthuis, Jetta Heeres, Michel Wesselink, Marco Ruis, Norbert

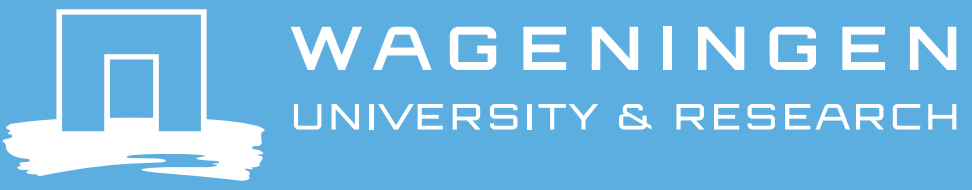





\title{
Pilotstudie implementatie welzijnsmonitor vleeskalveren
}

Kees van Reenen ${ }^{1}$, Maaike Wolthuis ${ }^{1}$, Jetta Heeres ${ }^{1}$, Michel Wesselink ${ }^{2}$, Marco Ruis ${ }^{1 / 3}$, Norbert Stockhofe ${ }^{4}$, Eddie Bokkers ${ }^{5}$

\author{
1 Wageningen Livestock Research \\ 2 Stichting Kwaliteitsgarantie Vleeskalveren \\ 3 Van Hall Larenstein \\ 4 Wageningen Bioveterinary Research \\ 5 Leerstoelgroep Animal Production Systems - WUR
}

Dit onderzoek is uitgevoerd door Wageningen Livestock Research, in opdracht van en gefinancierd door het Ministerie van Landbouw, Natuurbeheer en, in het kader van het Beleidsondersteunend onderzoek thema 'Welfare Qualty' (projectnummer BO-20.008-002-06).

Wageningen Livestock Research

Wageningen, mei 2021

OPENBAAR

Rapport 1300 
Kees van Reenen, Maaike Wolthuis, Jetta Heeres, Michel Wesselink, Marco Ruis, Norbert Stockhofe, Eddie Bokkers, 2021. Pilotstudie implementatie welzijnsmonitor vleeskalveren. Wageningen Livestock Research, Openbaar Rapport 1300.

Dit rapport is gratis te downloaden op https://doi.org/10.18174/546906 of op www.wur.nl/livestock-research (onder Wageningen Livestock Research publicaties).

\section{(cc) BY-NC}

Dit werk valt onder een Creative Commons Naamsvermelding-Niet Commercieel 4.0 Internationaallicentie.

(C) Wageningen Livestock Research, onderdeel van Stichting Wageningen Research, 2021

De gebruiker mag het werk kopiëren, verspreiden en doorgeven en afgeleide werken maken. Materiaal van derden waarvan in het werk gebruik is gemaakt en waarop intellectuele eigendomsrechten berusten, mogen niet zonder voorafgaande toestemming van derden gebruikt worden. De gebruiker dient bij het werk de door de maker of de licentiegever aangegeven naam te vermelden, maar niet zodanig dat de indruk gewekt wordt dat zij daarmee instemmen met het werk van de gebruiker of het gebruik van het werk. De gebruiker mag het werk niet voor commerciële doeleinden gebruiken.

Wageningen Livestock Research aanvaardt geen aansprakelijkheid voor eventuele schade voortvloeiend uit het gebruik van de resultaten van dit onderzoek of de toepassing van de adviezen.

Wageningen Livestock Research is NEN-EN-ISO 9001:2015 gecertificeerd.

Op al onze onderzoeksopdrachten zijn de Algemene Voorwaarden van de Animal Sciences Group van toepassing. Deze zijn gedeponeerd bij de Arrondissementsrechtbank Zwolle. 


\section{Inhoud}

$\begin{array}{ll}\text { Woord vooraf } & 5\end{array}$

$\begin{array}{ll}\text { Samenvatting } & 6\end{array}$

1

Inleiding

1.1 Aanleiding $\quad 9$

1.2 Overwegingen 9

1.3 Doelstelling $\quad 11$

$\begin{array}{lr}\text { Materiaal en methode } & 12\end{array}$

2.1 Kwaliteitscyclus $\quad 12$

2.2 SKV-waarnemers $\quad 12$

$\begin{array}{lll}2.3 & \text { Kalverhouders } & 13\end{array}$

2.4 Adviseur kalverhouder 13

2.5 Waarnemingen 13

2.5.1 Omschrijving parameters volgens de Welfare Quality ${ }^{\circledR} \quad 13$

$\begin{array}{ll}\text { 2.5.2 Waarnemingen vleeskalverbedrijf } & 14\end{array}$

$\begin{array}{ll}2.5 .3 \text { Slachthuis } & 17\end{array}$

$\begin{array}{lll}2.6 & \text { Rapportage } & 17\end{array}$

$\begin{array}{lll}2.7 & \text { Advies/plan van aanpak } & 20\end{array}$

$\begin{array}{lll}2.8 & \text { Kwantitatieve analyse } & 20\end{array}$

2.8.1 Uitkomsten training en herexamen van waarnemers 20

2.8.2 Gegevens waarnemingen op bedrijven $\quad 21$

2.9 Meningen kalverhouders en adviseurs $\quad 22$

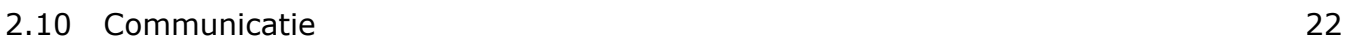

$\begin{array}{llr}3 & \text { Resultaten } & 23\end{array}$

3.1 Vereenvoudiging Welfare Quality ${ }^{\circledR}$ protocollen $\quad 23$

$\begin{array}{lll}3.2 & \text { Resultaten training en examen } & 23\end{array}$

3.2.1 Nauwkeurigheid beoordeling beschadigingen longen $\quad 23$

3.2.2 Nauwkeurigheid beoordeling pleuritis 24

3.3 Resultaten waarnemingen $\quad 25$

3.3.1 Het verloop van scores over rondes en effecten van seizoen $\quad 25$

3.3.2 Verbanden tussen verschillende rondes $\quad 25$

$\begin{array}{ll}3.3 .3 \text { Relaties tussen variabelen } & 27\end{array}$

3.3.4 Verschil tussen rose en blank 28

3.4 Praktische toepasbaarheid van het Welfare Quality ${ }^{\circledR}$ protocol voor vleeskalveren 29

$\begin{array}{lll}3.5 & \text { Adviezen aan kalverhouders } & 29\end{array}$

3.5.1 Binnenkomst adviezen $\quad 29$

$\begin{array}{ll}3.5 .2 & \text { Inhoud adviezen } \\ 3.5 .3 & 29\end{array}$

3.5.3 Opvolging en effect van adviezen $\quad 30$

3.5.4 Meningen van kalverhouders en adviseurs over de welzijnsmonitor $\quad 30$

$\begin{array}{lll}3.6 & \text { Kennisverspreiding } & 31\end{array}$

4.1 Vereenvoudiging Welfare Quality ${ }^{\circledR}$ protocollen 33

4.2 Resultaten waarnemingen 33

4.3 Bruikbaarheid Welfare Quality ${ }^{\circledR}$ protocol in de praktijk $\quad 35$

4.4 Aanbevelingen 36 
Bijlage 1 Anamnese 39

Bijlage 2 Protocol Calf Escape Test (CET) 40

Bijlage 3 Protocol drinkwatervoorziening, gladheid vloer en reinheid kalf 41

Bijlage 4 Protocollen pathologie $\quad 44$

Bijlage 5 Formulier voor adviseurs $\quad \mathbf{5 2}$

Bijlage 6 Gemiddelde scores per ronde op 44 blankvleesbedrijven 53

Bijlage 7 Gemiddelde scores per ronde op 21 rosé bedrijven 55

Bijlage 8 Overzicht van deeladviezen per onderdeel van de welzijnsmonitor 57

$\begin{array}{lll}\text { Bijlage } 9 & \text { Overzicht aanpassingen door kalverhouder } & 60\end{array}$

$\begin{array}{lll}\text { Bijlage } 10 & \text { Effect van gegeven adviezen } & 62\end{array}$

$\begin{array}{lll}\text { Bijlage } 11 & \text { Nieuwsbrief welzijnsmonitor }\end{array}$ 


\section{Woord vooraf}

Voor u ligt de eindrapportage van het project getiteld 'Pilotstudie implementatie welzijnsmonitor vleeskalveren'. In dit project is nauw samengewerkt tussen onderzoek en bedrijfsleven. Zonder de inzet van een groot aantal mensen had dit project niet uitgevoerd kunnen worden. Een woord van dank gaat in de eerste plaats uit naar de kalverhouders die bereid waren om hun bedrijf open te stellen voor het onderzoek, en hun visie te geven op de toepasbaarheid in de praktijk van de 'welzijnsmonitor vleeskalveren'. Daarnaast wil ik kalverspecialisten verbonden aan de integraties, medewerkers van voerleveranciers, en dierenartsen bedanken; zij hebben in het project de rol op zich genomen van adviseur, en de tijd genomen om kennis te nemen van de 'welzijnsmonitor vleeskalveren', en mee te denken over de bruikbaarheid van de monitoringsuitkomsten voor advies doeleinden. Tenslotte wil ik mijn grote waardering uitspreken voor de mensen van Stichting Kwaliteitsgarantie Vleeskalversector (SKV) die zorg hebben gedragen voor de planning en de uitvoering van de waarnemingen op de vleeskalverbedrijven en aan de slachtlijn.

Dr. Annemarie Rebel, Afdelingshoofd dierwelzijn en gezondheid, Wageningen Livestock Research 



\section{Samenvatting}

In dit onderzoek is de welzijnsmonitor vleeskalveren zoals eerder ontwikkeld in het kader van het Europese project Welfare Quality ${ }^{\circledR}$, uitgetest in een pilotstudie in de praktijk. De pilotstudie had vier subdoelstellingen: (1) het toetsen van de bruikbaarheid en praktische toepasbaarheid van de protocollen die deel uitmaken van de welzijnsmonitor op vleeskalverbedrijven in de praktijk, (2) het onderzoeken van de mogelijkheid om op basis van de meetresultaten een advies te geven aan de kalverhouder op het gebied van welzijn van vleeskalveren, (3) nagaan wat de effecten zijn van het adviseren op basis van deze metingen, en (4) het bevorderen van kennisverspreiding over het diergericht meten van het dierenwelzijn van vleeskalveren.

Aan het onderzoek hebben in totaal 65 vleeskalverbedrijven deelgenomen, 44 blankvleesbedrijven en 21 rosébedrijven. Op elk bedrijf is gedurende vier opeenvolgende mestrondes beoogd om een zogenaamde 'kwaliteitscyclus' te bewerkstelligen, waarbij (i) waarnemingen worden gedaan op het kalverbedrijf en op het slachthuis aan levende kalveren en organen, (ii) de uitkomsten worden geëvalueerd en besproken, (iii) een adviseur (van de integratie of de voerleverancier) en/of dierenarts een advies geeft aan de kalverhouder over manieren om het welzijn van de kalveren te verbeteren, (iv) de kalverhouder (vrijwillig) welzijnsverbeterende maatregelen neemt (in termen van huisvesting, voeding, verzorging) en (v) er bij de volgende ronde nadat de uitslag van de welzijnsmonitor bekend is opnieuw waarnemingen worden uitgevoerd om na te gaan in hoeverre de genomen maatregelen hebben geleid tot een verbetering van het welzijn van de kalveren. Als waarnemers fungeerden medewerkers van de Stichting Kwaliteitsgarantie Vleeskalversector (SKV), die daartoe voorafgaand aan de start van het onderzoek een individuele training hadden ondergaan, inclusief een afsluitend examen. In het laatste jaar van het project (ca. twee jaar na het eerste examen) zijn de waarnemers opnieuw bij elkaar geweest voor een onderlinge afstemming van de manier van beoordelen, en onderworpen aan een herexamen. De met behulp van een 'handheld computer' geregistreerde gegevens en waarnemingen van elke individuele koppel zijn door de SKV waarnemers digitaal aangeleverd bij Wageningen UR, en aldaar verwerkt tot een uniforme rapportage. Deze rapportage werd doorgestuurd naar de kalverhouder en zijn/haar adviseur, en werd gebruikt bij de evaluatie van de uitkomsten van de welzijnsmonitor. Behalve dat in het onderzoek de focus lag op de toepassing van de welzijnsmonitor in de praktijk en mogelijkheden voor advisering op grond van de uitkomsten, is ook aandacht besteed aan een kwantitatieve analyse van de monitoringsgegevens, waarbij werd nagegaan in hoeverre (i) parameters uit de welzijnsmonitor onderling samenhangen, (ii) verschillen tussen bedrijven consistent zijn over rondes heen, (iii) gemiddelde niveau's tussen rondes van elkaar verschillen, en (iv) de uitkomsten van de monitor op blankvleesbedrijven verschillen van die op rosébedrijven. Daarnaast zijn de gegevens met betrekking tot de beoordeling van longen aan de slachtlijn uit de training en (her)examens van de SKV waarnemers aan een systematische analyse onderworpen. Daarbij werd de mate waarin scores van de waarnemers overeenkomen met die van de trainer gekwantificeerd. Deelnemende kalverhouders en adviseurs zijn drie keer uitgenodigd voor een informatiebijeenkomst: één aan het begin van het project, één halverwege het project, en één aan het eind van het project (slotbijeenkomst). Tijdens deze bijeenkomsten werden de welzijnsmonitor en de opzet van het project toegelicht, en werden de uitkomsten, adviezen en resultaten besproken en gepresenteerd. Naast informatiebijeenkomsten zijn ook twee demonstratiebijeenkomsten georganiseerd op het slachthuis voor kalverhouders en adviseurs, waarbij de beoordeling van longen, pensen en lebmagen is uitgelegd door de veterinair patholoog van Wageningen UR. Over het project is tussentijds gerapporteerd naar kalverhouders in de vorm van nieuwsbrieven, artikelen in het tijdschrift De Kalverhouder, en op een wetenschappelijk congres.

De resultaten van het examen lieten zien dat de SKV waarnemers na afloop van de training een behoorlijke nauwkeurigheid in de manier van scoren van longen ten opzichte van de trainer (een ervaren veterinair patholoog die als referentie fungeerde) hadden bereikt. Uit het herexamen, ca. twee jaar later, bleek dat de nauwkeurigheid van scoren duidelijk was afgenomen. Niettemin waren de SKV waarnemers ook na twee jaar nog redelijk goed in staat om ernstig door longonsteking 
aangetaste longen te onderscheiden van minder of niet aangetaste longen. Voor een aantal parameters, met name pathologische afwijkingen aan de longen, beschadigingen in de lebmaagwand, en afwijkingen aan de penswand, waren de gemiddelde niveau's tijdens opeenvolgende rondes in dezelfde orde van grootte en relatief hoog. Daarnaast waren verschillen tussen vleeskalverbedrijven in luchtwegproblemen, zowel in termen van pathologische afwijkingen na slachting als met betrekking tot het klinische beeld op het vleeskalverbedrijf niet of nauwelijks consistent tussen rondes. Dit gold ook voor beschadigingen in de lebmaagwand. Deze bevindingen ondersteunen de gedachte dat naast factoren gerelateerd aan het vleeskalverbedrijf, vooral ook factoren gerelateerd aan de individuele koppel (zoals bijvoorbeeld de kwaliteit of herkomst van de kalveren) van invloed zijn op dit type gezondheidsproblemen. Verschillen tussen bedrijven in de reactie van kalveren op benadering door een persoon (tijdens een standaard gedragstest uitgevoerd in het hok) en - alleen op blankvleesbedrijven - de mate van uniformiteit van kalveren in hetzelfde hok, waren juist uitzonderlijk consistent tussen rondes. Op deze variabelen had het vleeskalverbedrijf blijkbaar een relatief groot effect; dit lijkt ook aannemelijk gelet op het feit dat zowel de reactie van kalveren op een persoon als de mate van uniformiteit van kalveren in hetzelfde hok op een vleeskalverbedrijf bij uitstek samen hangen met het management - zoals het sorteerbeleid - van de individuele kalverhouder en de wijze waarop hij/zij met de kalveren omgaat. Klinische variabelen met betrekking tot luchtwegproblemen en post-mortem geregistreerde afwijkingen aan longen waren onderling gecorreleerd, zowel bij blankvlees- als bij rosékalveren. Dit betekent dat bij koppels waar rond week 13 op het vleeskalverbedrijf relatief veel klinische luchtwegproblemen waarneembaar waren de longen na slachting eveneens veel beschadigingen en gevallen van pleuritis lieten zien. Gemiddeld over de vier rondes heen verschilden rosébedrijven significant van blankvleesbedrijven voor wat betreft de niveau's van een aantal welzijjnsparameters, in het bijzonder klinische en post mortem bevindingen gerelateerd aan luchtwegproblemen (hoger op rosébedrijven), afwijkingen aan het maagdarmkanaal zoals plaques in de pens en lebmaaglesies (lager op rosébedrijven), en abnormaal oraal gedrag (lager op rosébedrijven). Dit verschil komt overeen met verschillen die in eerder onderzoek aan de welzijnsmonitor zijn gevonden. Alle bevindingen bij elkaar laten zien dat de welzijnsprotocollen die in deze praktijkstudie zijn gehanteerd voor een belangrijk deel valide en betrouwbaar lijken, in ieder geval daar waar het de detectie van relatieve verschillen in gezondheids- en welzijnsparameters tussen koppels, tussen bedrijven en tussen systemen (blankvlees versus rosé) betreft.

In de proefperiode zijn over alle bedrijven heen in totaal 256 mestrondes voltooid; er zijn derhalve ook 256 rapportages uitgebracht en verstuurd naar kalverhouder en adviseur. Uiteindelijk zijn in totaal 97 adviezen uitgebracht; dat is $38 \%$ van de 256 adviezen die maximaal mogelijk waren geweest. De aard en reikwijdte van de verstrekte adviezen waren zeer divers, en voor hetzelfde probleem, zoals bijvoorbeeld aandoeningen van kalveren aan de luchtwegen of het maagdarmkanaal, werden vaak zeer verschillende deeladviezen gegeven. Van 6 kalverbedrijven werd na afloop van elk van de vier rondes een volledig advies ontvangen. Op deze bedrijven is ook naar de effecten van de gegeven (deel)adviezen gekeken: de genomen maatregelen waren zeer divers, en de effecten in termen van de uitkomsten van de welzijnsmonitor tijdens de volgende ronde leken soms positief, soms neutraal en soms negatief. Ongeveer $25 \%$ van zowel kalverhouders als adviseurs heeft tenminste één van de informatie- en demonstratiebijeenkomsten bezocht. Deze bijeenkomsten werden over het algemeen als positief beoordeeld. De meningen van de deelnemende kalverhouders en adviseurs over de welzijnsmonitor waren zeer uiteenlopend, van positief tot neutraal tot negatief. Een punt van kritiek betrof de rapportage van gegevens, waarbij het accent lag op de vergelijking van de uitkomsten met vooraf bepaalde normen. Er is vervolgens binnen het project ook gewerkt aan alternatieve vormen van presentatie waarbij het accent ligt op vergelijking van de eigen uitkomsten met die van andere bedrijven (benchmarking). Veel deelnemende kalverhouders gaven aan dat belangrijke factoren die van invloed zijn op de gezondheid van vleeskalveren zich voor een groot deel buiten hun invloedssfeer bevinden. Daarbij werd vooral gedoeld op de kwaliteit van de kalveren bij opzetten, en (m.n. voor blankvlees) de kwaliteit van het rantsoen (kalvermelk en ruw- en krachtvoer). Tenslotte werd opgemerkt door kalverhouders en adviseurs dat de gegevens van de welzijnsmonitor eigenlijk gecombineerd zouden moeten worden met andere informatiebronnen, bijvoorbeeld ten aanzien van het rantsoen, de herkomst en de kwaliteit van de kalveren, de technische resultaten en het gebruik van antibiotica. 
Het onderzoek heeft laten zien dat het in principe mogelijk is om erfbetreders, zoals SKV buitendienst medewerkers, die voorafgaand aan het onderzoek geen specifieke voorkennis over het protocol hadden, redelijk betrouwbare waarnemingen te laten verrichten in de praktijk in het kader van de welzijnsmonitor vleeskalveren. Een goede training is daarbij wel een cruciale voorwaarde. De betrokkenheid van kalverhouders en adviseurs bij het project was minder groot dan gewenst; ongeveer een kwart van de deelnemende kalverhouders en adviseurs namen deel aan informatie- en demonstratiebijeenkomsten, en ruim een derde van de rapportages leidde tot een advies. Uit de verstrekte adviezen kwam naar voren dat adviseurs aanzienlijk verschillen in hun adviezen aan kalverhouders naar aanleiding van de uitkomsten van de welzijnsmonitor vleeskalveren. Dit suggereert dat er in de praktijk geen duidelijke consensus bestaat over de aanpak en oplossing van algemeen voorkomende gezondheids- en welzijnsproblemen van vleeskalveren. De in dit project gedocumenteerde adviezen en maatregelen representeren feitelijk alle mogelijke opties die een kalverhouder en zijn/haar adviseur op basis van gezond verstand ten dienste staan. Uit de uitslagen van de welzijnsmonitor blijkt dat er in de vleeskalverhouderij sprake lijkt te zijn van een aantal hardnekkige gezondheids- en welzijnsproblemen, waarop voor een belangrijk deel nietbedrijfsgerelateerde factoren invloed hebben. Dit geldt in het bijzonder voor luchtwegproblemen. Dit zou mede kunnen verklaren waarom maatregelen op een individueel kalverbedrijf op de korte termijn - binnen het bestek van een viertal opeenvolgende mestrondes - niet erg effectief zijn. Deze gegevens zijn relevant wanneer wordt nagedacht over effectieve strategieën ter verbetering van de (luchtweg)gezondheid van vleeskalveren

Voor het op een zinvolle manier implementeren en benutten van (elementen) van de welzijnsmonitor vleeskalveren, gericht op een verbetering van gezondheid en welzijn van vleeskalveren in de gehele keten, worden aan het eind van dit rapport aanbevelingen gedaan. 



\section{$1 \quad$ Inleiding}

\section{$1.1 \quad$ Aanleiding}

De Nederlandse overheid heeft zich ten doel gesteld om dierenwelzijn te bevorderen en bovenwettelijke maatschappelijke prestaties op dit terrein te belonen (zie, bijvoorbeeld, het CDA VVD Regeerakkoord "Vrijheid en Verantwoordelijkheid" van 30 september 2010). In dit verband is er grote behoefte aan methoden om het welzijn van (landbouwhuis)dieren objectief en op een eenduidige manier vast te stellen. Het internationale project Welfare Quality ${ }^{\circledR}$ heeft een vernieuwende systematiek ontwikkeld om het welzijn van pluimvee, varkens, en runderen (melk- en vleesvee) op het primaire bedrijf hoofdzakelijk te meten aan de hand van diergerichte indicatoren (gedrags- en gezondheidskenmerken). Ook voor vleeskalveren zijn protocollen volgens deze systematiek ontwikkeld.

Aan de hand van metingen aan het dier en diens directe omgeving kan een betrouwbare inschatting worden gemaakt van het welzijn van het dier op het primaire bedrijf. Dit inzicht is van wezenlijk belang voor een ondernemer die geïnteresseerd is in het welzijn van zijn dieren en daarop wil sturen. Ook andere ketenpartijen en overheden kunnen gebruik maken van gegevens over het niveau van dierenwelzijn op een dierhouderij of in een sector. Objectieve informatie over het niveau van welzijn van landbouwhuisdieren kan gebruikt worden voor communicatie naar de maatschappij, en naar consumenten van dierlijke producten (bijvoorbeeld via een dierenwelzijnslabel zoals het Beter Leven Kenmerk van de Dierenbescherming). Ook kan Welfare Quality ${ }^{\circledR}$ (WQ) ingezet worden bij het vormgeven van doelvoorschriften.

Eind 2009 heeft Welfare Quality ${ }^{\circledR}$ haar resultaten opgeleverd, onder meer in de vorm van gebundelde welzijnsprotocollen voor pluimvee (leghennen en vleeskuikens), varkens (zeugen en vleesvarkens) en runderen (melkkoeien, vleesvee en vleeskalveren). Aan het protocol voor vleeskalveren is nog tot eind 2011 verder gewerkt door het consortium met partners uit Italië, Frankrijk en Nederland, en de versie die in dit onderzoek is opgeleverd vormt de basis voor herziene protocollen die WQ in 2012 zijn vrijgeven (zie Brscic et al., 2011)

Het regelmatig meten van het niveau van welzijn van landbouwhuisdieren met behulp van de protocollen die in WQ zijn ontwikkeld is een tijdrovende en kostbare aangelegenheid. Er is daarom in 2011 onderzoek gedaan naar de mogelijkheden om te komen tot vereenvoudigde protocollen. In de kalversector is tijdswinst te boeken zonder teveel aan kwaliteit in te boeten door een aantal (gedrags)waarnemingen minder lang uit te voeren (Biometris en Wageningen Livestock Research, 2012). Of een dergelijke vereenvoudiging ook onder praktijkomstandigheden toegepast kan worden is nog onbekend. In algemene zin bestaat de behoefte om het meten van het welzijn van vleeskalveren met behulp van een dergelijke (vereenvoudigde) methode te beproeven in de praktijk.

\subsection{Overwegingen}

In de periode 2005 - 2012 is door een consortium van kennisinstellingen en partijen uit de vleeskalversector afkomstig uit de drie belangrijkste kalfsvleesproducerende landen in Europa - Italië, Frankrijk en Nederland een welzijnsmonitor voor vleeskalveren ontwikkeld. Dit werk is voor een deel uitgevoerd binnen het Europese project Welfare Quality ${ }^{\circledR}$ (WQ), en de ontwikkelde protocollen zijn door het WQ network overgenomen als standaard voor vleeskalveren. Bij de ontwikkeling van deze monitor is een zogenaamde 'bottom up' benadering gevolgd. Dat wil zeggen dat alle protocollen van het begin af aan in nauwe samenwerking met relevante partijen uit de vleeskalversector zijn ontwikkeld. In Nederland zijn alle (tussen)resultaten ook intensief besproken met het Ministerie van LNV en met een belangrijke maatschappelijke stakeholder, i.c. de Dierenbescherming. Op deze manier 
is bewerkstelligd dat er bij het opleveren van de welzijnsmonitor in ieder geval bij de partijen en stakeholders die bij het onderzoek betrokken waren een redelijke mate van consensus bestond over de inhoud van de protocollen. In het afgelopen onderzoek stond de kwaliteit van de verzamelde onderzoeksgegevens voorop, en daarom is voor de uitvoering van waarnemingen op vleeskalverbedrijven in de praktijk gebruik gemaakt van professionele vleeskalverdierenartsen en onderzoekers van Wageningen UR. Daarnaast waren alle onderzoeksinspanningen tot nu toe gericht op het ontwikkelen van het monitoringsinstrument en is nog niet of nauwelijks aandacht besteed aan het gebruik daarvan door de vleeskalverhouder en andere betrokkenen bij het primaire productieproces, zoals technische medewerkers van de vleeskalverintegraties of dierenartsen. Dit betekent dat de welzijnsmonitor voor vleeskalveren zoals die dat moment beschikbaar was nog niet 'rijp' was voor een algemene toepassing in de praktijk. Daarvoor is aanvullende kennis en ervaring nodig. Dit onderzoek is primair bedoeld om die kennis en ervaring te genereren op basis waarvan (al of niet) concrete stappen gezet zouden kunnen worden in de richting van de toepassing in de praktijk van de welzijnsmonitor voor vleeskalveren. Daarbij zijn de volgende overwegingen van belang geweest:

Wil een welzijnsmonitor in de praktijk toepasbaar zijn, dan is naast wetenschappelijke validiteit de haalbaarheid een zeer belangrijke voorwaarde. De haalbaarheid van de welzijnsmonitor vleeskalveren zou sterk toenemen wanneer de waarnemingen op vleeskalverbedrijven en slachterijen gedaan zouden kunnen worden door personen werkzaam in de vleeskalversector zelf (b.v. bij een integratie) of bij organisaties die nauw met de vleeskalversector zijn verbonden (b.v. SKV), in plaats van door onderzoekers van Wageningen UR of dierenartsen. In dit onderzoek is gekozen om de waarnemingen te laten uitvoeren door medewerkers van Stichting Kwaliteitsgarantie Vleeskalveren (SKV). SKV was op voorhand de meest logische partij in dit verband omdat SKV nu al routinematig op vleeskalverbedrijven en slachterijen diverse controles uitvoert, waaronder IKB vleeskalveren controle en sinds kort ook controles in het kader van het 'Beter leven concept' van de Dierenbescherming.

Een ander aspect van haalbaarheid van een welzijnsmonitor is de omvang en mate van detail; hoe omvangrijker en gedetailleerder hoe kostbaarder in termen van benodigde mankracht en tijd (en daarmee geld). Vereenvoudiging van de welzijnsmonitor zou een manier kunnen zijn om te komen tot een minder omvangrijk en gedetailleerd, en daardoor een beter haalbaar systeem. In dit onderzoek wordt een vereenvoudigde versie van de welzijnsmonitor vleeskalveren met behulp van een statistische analyse afgezet tegen de meest uitgebreide variant. Dit is feitelijk een herhaling van een analyse die al eerder is uitgevoerd door Wageningen UR Livestock Research. De verantwoordelijkheid van WUR voor het onderzoek dat in deze rapportage wordt beschreven garandeert continuïteit van de eerder opgedane kennis op dit punt.

Voor een succesvolle implementatie in de praktijk van een welzijnsmonitor voor vleeskalveren is het essentieel dat met behulp daarvan gegevens worden verzameld die relevant zijn voor het management en de bedrijfsvoering op het vleeskalverbedrijf. Dat betekent dat (i) de resultaten van welzijnsmonitoring in de praktijk aansluiten bij de belevingswereld van de vleeskalverhouder en andere betrokkenen bij het primaire productieproces, en daarmee aanleiding geven tot bewustwording op het terrein van het welzijn van vleeskalveren, en dat daardoor (ii) op basis van de resultaten van de welzijnsmonitor zinvolle adviezen kunnen worden gegeven ten aanzien van het management en de verzorging van vleeskalveren, met de bedoeling om concrete maatregelen te nemen waarmee het welzijn van de dieren wordt verbeterd. In dit kader voorziet het onderzoek niet alleen in een systematische analyse van de adviezen en maatregelen die naar aanleiding van de resultaten van de welzijnsmonitor worden verkregen, maar wordt ook een acceptatieonderzoek uitgevoerd om de achterliggende motieven van de vleeskalverhouder en de adviseur te achterhalen. Hiervoor is een samenwerking aangegaan met Van Hall Larenstein in Leeuwarden. 


\subsection{Doelstelling}

De doelstellingen van dit onderzoek zijn:

- De bruikbaarheid van de (vereenvoudigde) Welfare Quality ${ }^{\circledR}$ protocollen in de praktijk op vleeskalverbedrijven toetsen.

- De mogelijkheid onderzoeken om op basis van de meetresultaten een advies te geven aan de kalverhouder op het gebied van welzijn van vleeskalveren

- Nagaan wat de effecten zijn van het adviseren op basis van deze metingen.

- Kennisverspreiding over het diergericht meten van het dierenwelzijn van vleeskalveren bevorderen.

Aan het eind van het project is duidelijk of het (vereenvoudigde) protocol bruikbaar is om het welzijn op het primaire vleeskalverbedrijf te meten en op basis van deze metingen een advies gegeven kan worden aan de kalverhouder, en wat de effecten zijn van het adviseren op basis van de metingen. Daarnaast is richting de hele sector, inclusief verwerkende industrie, gecommuniceerd over dit project en het meten van welzijn van vleeskalveren volgens WQ. 


\section{Materiaal en methode}

\section{$2.1 \quad$ Kwaliteitscyclus}

In het project is beoogd om een zogenaamde 'kwaliteitscyclus' (zie figuur 1) te bewerkstelligen, waarbij (i) waarnemingen worden gedaan op het kalverbedrijf en op het slachthuis aan levende kalveren en organen, (ii) de uitkomsten worden geëvalueerd en besproken, (iii) een adviseur (bijvoorbeeld van de integratie of de voerleverancier) en/of dierenarts een advies geeft aan de kalverhouder over manieren om het welzijn van de kalveren te verbeteren, (iv) de kalverhouder (vrijwillig) welzijnsverbeterende maatregelen neemt (in termen van huisvesting, voeding, verzorging) en $(v)$ er bij de volgende ronde nadat de uitslag van de welzijnsmonitor bekend is opnieuw waarnemingen worden uitgevoerd om na te gaan in hoeverre de genomen maatregelen hebben geleid tot een verbetering van het welzijn van de kalveren. Op deze manier zijn de bedrijven gedurende 4 ronden gevolgd.

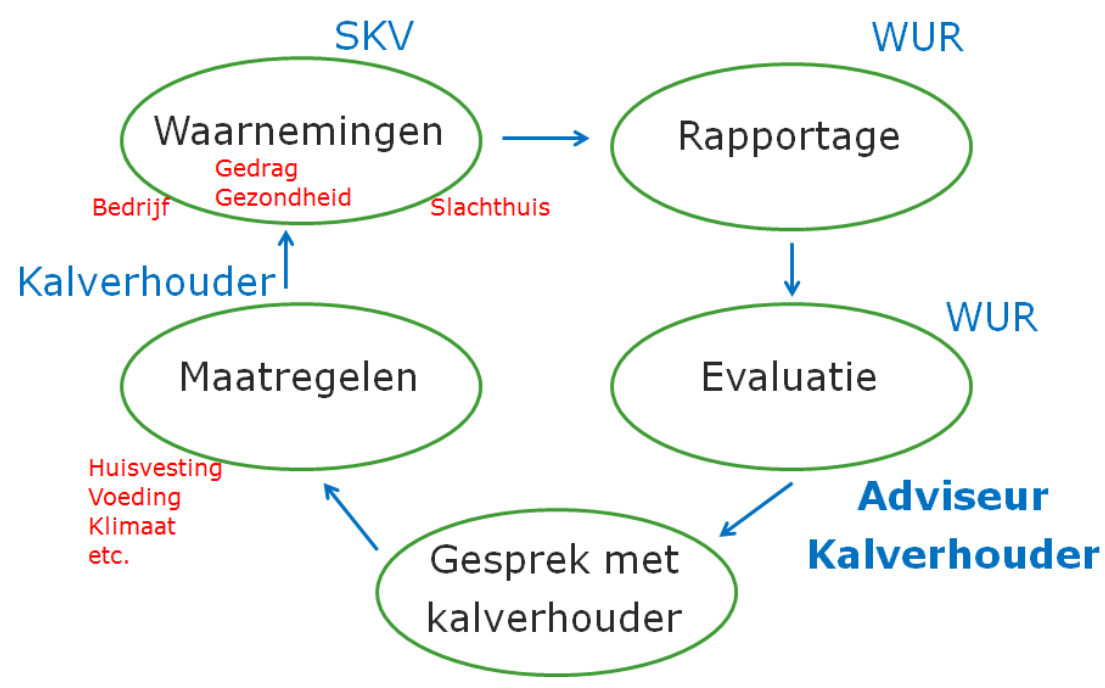

Figur 1 Kwaliteitscyclus welzijn vleeskalveren.

\subsection{SKV-waarnemers}

Er zijn vier SKV waarnemers getraind voor de waarnemingen op de kalverbedrijven en zes SKV waarnemers voor waarnemingen op de slachthuizen. Voor beide waarnemingen is vóór de start van het project een training georganiseerd. De training werd afgesloten met een examen waarbij de waarnemer in opleiding dezelfde kalveren en/of organen beoordeelde als een ervaren waarnemer die als referentie fungeerde. Als referentie voor waarnemingen van het gedrag, de klinische gezondheid en pathologische afwijkingen aan organen fungeerden, respectievelijk, Maaike Wolthuis (gedragsonderzoeker WUR), Teus Kreuger (vleeskalverdierenarts Diergezondheidscentrum Boven Veluwe) en Norbert Stockhofe (veterinair patholoog WBVR). Het examen werd als succesvol afgesloten beschouwd wanneer de SKV waarnemer bij minimaal $80 \%$ van de beoordeelde kalveren en/of organen dezelfde score had gegeven als de referentie. Alle SKV waarnemers hebben aan dit criterium voldaan. In het laatste jaar van het project zijn de waarnemers opnieuw bij elkaar geweest voor een onderlinge afstemming van de manier van beoordelen, en onderworpen aan een herexamen (ca. twee jaar na het eerste examen). Het herexamen werd afgenomen volgens dezelfde systematiek als het examen na afloop van de training voorafgaand aan de training aan het begin van het project. Ook het herexamen is door de SKV waarnemers in grote lijnen succesvol afgesloten. Op de uitslagen van de examens is een statistische analyse toegepast (zie paragraaf 2.8 van dit rapport, kwantitatieve analyse). 


\subsection{Kalverhouders}

In totaal hebben 65 vleeskalverbedrijven aan het onderzoek meegedaan; 44 blankvlees bedrijven en 21 rosé bedrijven gedurende 4 mestronden. Bij de blankvleesbedrijven is één keer door onvoorziene omstandigheden een slacht gemist en één bedrijf is na twee ronden met de bedrijfsvoering gestopt. Bij de rosé bedrijven zijn er 2 bedrijven geweest die kalveren als oud rosé afmesten en door de lange mestduur per ronde bleek een $4^{\mathrm{e}}$ ronde binnen de looptijd van het project niet haalbaar.

\subsection{Adviseur kalverhouder}

Aan elk bedrijf is gevraagd een adviseur voor zijn bedrijf op te geven. Voor bedrijven die bij een integratie aangesloten zijn waren dit bedrijfsbegeleiders vanuit de integraties. Bedrijfsbegeleiders zijn door integraties aangestelde functionarissen die verantwoordelijk zijn voor de begeleiding van kalverhouders bij het houden van vleeskalveren. Het betreft hier diergezondheids- welzijns- en economische aspecten. Bij kalverhouders die geen contract met een integratie hebben is of gebruik gemaakt van de begeleider van de voerleverancier of is de dierenarts als adviseur opgetreden. Er zijn in totaal drie bijeenkomsten gehouden om de beoogde adviseurs te informeren over de welzijnsmonitor en de rol die zijn daarin spelen. Aan het einde van de bijeenkomst ontvingen zij een informatiepakket met de achtergrondinformatie van het project, een overzicht van de waarnemingen die uitgevoerd worden en uitleg over zijn of haar rol in het project.

\subsection{Waarnemingen}

\subsubsection{Omschrijving parameters volgens de Welfare Quality ${ }^{\circledR}$}

Tabel 1 geeft een overzicht van de parameters volgens de indeling van de Welfare Quality ${ }^{\circledR}$ systematiek, zoals deze voor alle diersoorten gebruikt is. De parameters zijn op te delen in deelprotocollen voor klinische gezondheid, gedrag, pathologie en overige protocollen. Omdat waarnemingen in de praktijk per (gecombineerde) deelprotocollen uitgevoerd zijn worden deze in de volgende paragrafen in detail beschreven.

Tabel 1 Indeling van dier- (22) en omgevingsparameters (3) in Criteria en Principes volgens de Welfare Quality ${ }^{\circledR}$ systematiek.

\begin{tabular}{|c|c|c|c|c|}
\hline Principe & & Criteria & Dierparameter & Omgevingsparameter \\
\hline \multirow[t]{2}{*}{$\begin{array}{c}\text { Goede } \\
\text { voeding }\end{array}$} & 1 & $\begin{array}{l}\text { Afwezigheid van } \\
\text { langdurige honger }\end{array}$ & Achterstand conditie $(K)$ & \\
\hline & 2 & $\begin{array}{l}\text { Afwezigheid van } \\
\text { langdurige dorst }\end{array}$ & & $\begin{array}{l}\text { Watervoorziening }(O) \text {; } \\
\text { aantal en reinheid van } \\
\text { drinkpunten }\end{array}$ \\
\hline \multirow[t]{3}{*}{$\begin{array}{c}\text { Goede } \\
\text { huisvesting }\end{array}$} & 3 & Ligcomfort & $\begin{array}{l}\text { Bursa }(K) \text {; Reinheid van de } \\
\text { kalveren }(O)\end{array}$ & \\
\hline & 4 & $\begin{array}{l}\text { Thermaal comfort } \\
\text { (temperatuur) }\end{array}$ & Natte kalveren $(K)$ & \\
\hline & 5 & Bewegingsvrijheid & & Gladheid van de vloer $(O)$ \\
\hline $\begin{array}{c}\text { Goede } \\
\text { gezondheid }\end{array}$ & 6 & $\begin{array}{l}\text { Afwezigheid van } \\
\text { letsel }\end{array}$ & Kreupelheid; Verwondingen (K) & \\
\hline
\end{tabular}




\begin{tabular}{|c|c|c|c|c|}
\hline \multicolumn{2}{|l|}{ Principe } & \multirow{2}{*}{$\begin{array}{l}\text { Criteria } \\
\text { Afwezigheid van } \\
\text { ziekte }\end{array}$} & \multirow[b]{2}{*}{$\begin{array}{l}\text { Dierparameter } \\
\text { Hoesten; Abnormale } \\
\text { ademhaling; Neusuitvloeiing }(K) \text {; } \\
\text { Longontsteking; Pleuritis; } \\
\text { Laesies in de lebmaag; Plaques } \\
\text { in de pens }(P) ; \\
\text { Volle kalveren, Dorre kalveren; } \\
\text { Zieke kalveren }(K) ; \\
\text { Hemoglobinegehalte; Uitval }(O)\end{array}$} & \multirow{2}{*}{$\begin{array}{l}\text { Omgevingsparameter } \\
\text { Dunne mest }(K)\end{array}$} \\
\hline & 7 & & & \\
\hline & 8 & $\begin{array}{l}\text { Afwezigheid van } \\
\text { pijn veroorzaakt } \\
\text { door ingrepen }\end{array}$ & Niet relevant voor vleeskalveren & $\begin{array}{l}\text { Niet relevant voor } \\
\text { vleeskalveren }\end{array}$ \\
\hline \multirow[t]{4}{*}{$\begin{array}{l}\text { Normaal } \\
\text { gedrag }\end{array}$} & 9 & $\begin{array}{l}\text { Normaal sociaal } \\
\text { gedrag }\end{array}$ & Sociaal gedrag $(G)$ & \\
\hline & 10 & $\begin{array}{l}\text { Normaal ander } \\
\text { gedrag }\end{array}$ & $\begin{array}{l}\text { Abnormaal oraal gedrag }(G) ; \\
\text { Urine drinken/bezuigen } \\
\text { preputium soortgenoot }(K / G)\end{array}$ & \\
\hline & 11 & $\begin{array}{l}\text { Goede mens-dier } \\
\text { relatie }\end{array}$ & Angst voor de mens $(G)$ & \\
\hline & 12 & $\begin{array}{l}\text { Positieve } \\
\text { emotionele } \\
\text { toestand }\end{array}$ & $\begin{array}{l}\text { Qualitative Behaviour } \\
\text { Assessment }(Q B A)^{*}\end{array}$ & \\
\hline
\end{tabular}

(K): Onderdeel van klinisch protocol

(G): Onderdeel van het gedragsprotocol

$(P)$ : Onderdeel van het pathologisch protocol

(O): Overige parameters

(QBA)*: De QBA is voor Welfare Quality alleen in Italië bij 24 bedrijven uitgevoerd en zal in Nederland niet toegepast worden.

\subsubsection{Waarnemingen vleeskalverbedrijf}

Waarnemingen op het vleeskalverbedrijf zijn op 13 weken stalleeftijd uitgevoerd en bestonden uit klinische- en gedragsobservaties, ook is er gekeken naar drinkwatervoorzieningen, gladheid van vloeren en reinheid van de kalveren.

\section{Klinische observaties}

Bij de uitvoering van het klinisch protocol is ook een anamnese (zie bijlage 1) uitgevoerd. Dit zijn vragen welke deels voorafgaand aan de monitor en deels na de monitor aan de kalverhouder gevraagd worden. Deze anamnese geeft een algemene indruk van het koppel. Het klinisch protocol is bij 300 kalveren per bedrijf uitgevoerd en de kalveren zijn op groepshok niveau beoordeeld, waarbij hokken random over het bedrijf zijn geselecteerd. Daarnaast zijn alle kalveren in de ziekenboeg beoordeeld.

Bij elk geobserveerd hok zijn de volgende vragen beantwoord:

1. Hoeveel kalveren hebben een afwijkende ademhaling die indicatief is voor longproblemen?

2. Hoeveel kalveren hebben een matig of ernstige vorm van neusuitvloeiing?

3. Hoeveel kalveren hoesten?

4. Ligt er verse diarree in het hok?

5. Hoeveel volle kalveren zijn er?

6. Hoeveel kreupele kalveren zijn er in het hok?

7. Hoeveel kalveren hebben een verkregen slijmbeurs?

8. Hoeveel kalveren hebben een aangebeten staart of oor?

9. Hoeveel kalveren vallen in de categorie 'urine zuigen'?

10. Hoeveel kalveren hebben een achterstand in conditie en gewicht van $15-30 \%$ t.o.v. koppel?

11. Hoeveel kalveren hebben een achterstand in conditie en gewicht van $>30 \%$ t.o.v. koppel?

12. Hoeveel kalveren hebben een natte vacht?

13. Hoeveel kalveren hebben een dof/dor haarkleed?

14. Hoeveel duidelijke slome en zieke kalveren zijn er in het hok? 


\section{Gedrag}

Het gedrag van de kalveren is op 2 onderdelen beoordeeld: via directe gedragsobservaties en de zogenaamde Calf Escape Test.

Gedragsobservaties in het eigen hok zonder verstoring

Gedragsobservaties zijn via scan sampling uitgevoerd, waarbij elke 2 minuten het gedrag van alle kalveren in het hok genoteerd is volgens een vooraf vastgelegd ethogram (zie Tabel 3). Tijdens de eerste ronde zijn deze gedragsobservaties op drie verschillende momenten op de dag uitgevoerd. Een keer aan het begin van de dag, een keer tijdens de rustperiode en een keer voor voeren, aan het einde van de dag. In totaal zijn er 36 hokken geobserveerd bij kleine groepen (4-10 kalveren) en 9 hokken bij kalveren in grote groepen van meer dan 20 kalveren (zie Tabel 2 voor een overzicht). $\mathrm{Bij}$ de ronden erna is de frequentie teruggebracht van 3 naar 1 tijdstip. Dat zijn dus 12 hokken bij kleine groepen en 3 hokken bij grote groepen (zie Tabel 2).

Tabel 2 Overzicht van gedragsobservaties.

\begin{tabular}{|c|c|c|c|c|}
\hline Periode & Ronde 1 & Ronde 2 & Ronde 3 & Ronde 4 \\
\hline \multicolumn{5}{|c|}{ Begin van de dag: } \\
\hline Kleine groepen & $3 \times 4$ hokken & $3 \times 4$ hokken & $3 \times 4$ hokken & $3 \times 4$ hokken \\
\hline Grote groepen & $3 \times 1$ hok & $3 \times 1$ hok & $3 \times 1$ hok & $3 \times 1$ hok \\
\hline \multicolumn{5}{|l|}{ Rustperiode: } \\
\hline Kleine groepen & $3 \times 4$ hokken & & & \\
\hline Grote groepen & $3 \times 1$ hok & & & \\
\hline \multicolumn{5}{|l|}{ Voor voeren: } \\
\hline Kleine groepen & $3 \times 4$ hokken & & & \\
\hline Grote groepen & $3 \times 1$ hok & & & \\
\hline \multicolumn{5}{|l|}{ Totaal } \\
\hline Kleine groepen: & 36 hokken & 12 hokken & 12 hokken & 12 hokken \\
\hline Grote groepen & 9 hokken & 3 hokken & 3 hokken & 3 hokken \\
\hline
\end{tabular}

* Elk hok is gedurende 10 minuten waargenomen

\section{Calf Escape Test (CET)}

De CET is een test om de reactie van het kalf te meten op een actieve benadering van een onbekende persoon.

De waarnemer gaat het hok in. Vervolgens gaat de waarnemer op een rustige, gestandaardiseerde manier naar een kalf in het hok, waarna hij/zij probeert met de hand de snuit van het kalf te raken. Reacties van het kalf worden genoteerd evenals de afstand tot het kalf op het moment dat een reactie optreedt (zie voor uitgebreid protocol Bijlage 2). De CET is steeds uitgevoerd bij 100 kalveren per bedrijf. 


\section{GEDRAGSCATEGORIE GEDRAGING}

\section{Houding}

Liggen flank

Liggen borstbeen

Liggen borstbeen + poot gestrekt L3

\begin{tabular}{|c|c|c|c|}
\hline & Staan & $\mathrm{S}$ & Kalf staat op 3 of vier benen \\
\hline & Liggen flank & L1 & Kalf ligt op zijn flank met zijn vier poten gestrekt \\
\hline & Liggen borstbeen & L2 & $\begin{array}{l}\text { Kalf ligt met zijn } 2 \text { voorpoten poten onder zijn lichaam, } \\
\text { kop kan weggedraaid liggen }\end{array}$ \\
\hline & Liggen borstbeen + poot gestrekt & L3 & $\begin{array}{l}\text { Kalf ligt met } 1 \text { of } 2 \text { voorpoten gestrekt, kop kan } \\
\text { weggedraaid liggen., }\end{array}$ \\
\hline \multicolumn{4}{|l|}{ Gedrag } \\
\hline \multirow[t]{4}{*}{ Algemeen } & Lopen & $\mathrm{Y}$ & Kalf loopt door het hok (niet rennen/springen/ dartelen) \\
\hline & Geen activiteit & $\mathrm{G}$ & $\begin{array}{l}\text { Het kalf ligt of staat zonder enig ander activiteit uit te } \\
\text { voeren. }\end{array}$ \\
\hline & Niet zichtbaar & $\mathrm{X}$ & Gedrag van het kalf is niet zichtbaar voor de waarnemer. \\
\hline & Overig & $\mathrm{O}$ & $\begin{array}{l}\text { Het kalf toont een gedrag wat niet in het ethogram } \\
\text { beschreven is. }\end{array}$ \\
\hline \multirow[t]{5}{*}{ Eet gedrag } & Melk drinken & M & Het kalf drinkt melk uit de emmer, trog of melkstation \\
\hline & Water drinken & W & $\begin{array}{l}\text { Het kalf drinkt water uit emmer, trog, drinknippel of } \\
\text { waterbak. }\end{array}$ \\
\hline & Eten ruwvoer & $E$ & Het kalf eet het ruwvoer wat hij tot zijn beschikking heeft \\
\hline & (Her)kauwen & $\mathrm{H}$ & Alle kauwbewegingen die het kalf met zijn mond maakt. \\
\hline & Likken aan mineralenblok & A & Kalf likt aan het mineralenblok \\
\hline \multirow[t]{3}{*}{ Comfort gedrag } & Zelflikken & Z & Kalf likt zichzelf, inclusief snuit/ neus. \\
\hline & Krabben/schuren & $\mathrm{K}$ & $\begin{array}{l}\text { Kalf krabt zichzelf of schuurt met zijn lichaam langs een } \\
\text { object }\end{array}$ \\
\hline & Rekken/strekken & $\mathrm{R}$ & Kalf rekt of strekt zich uit \\
\hline \multirow[t]{4}{*}{ Abnormaal oraal gedrag } & Tong spelen/rollen & $\mathrm{T}$ & $\begin{array}{l}\text { Kalf maakt repeterende bewegingen met de tong binnen } \\
\text { of buiten de bek }\end{array}$ \\
\hline & Urine drinken/ preputium zuigen & $U$ & $\begin{array}{l}\text { Kalf drinkt of likt de urine van een soortgenoot of bij } \\
\text { zichzelf, of zuigt aan het preputium van een soortgenoot,. }\end{array}$ \\
\hline & Oraal manipuleren object & 1 & $\begin{array}{l}\text { Kalf likt, knabbelt, zuigt, bijt aan hek, wand, emmer, trog, } \\
\text { vloer en object al dan niet op een stereotype manier. Een } \\
\text { object is elk attribuut dat is toegevoegd in de hokken } \\
\text { zonder direct nut (speeltjes) }\end{array}$ \\
\hline & Oraal manipuleren ander kalf & 2 & $\begin{array}{l}\text { Kalf zuigt of bijt aan een soortgenoot al dan niet op een } \\
\text { stereotype manier. }\end{array}$ \\
\hline \multirow[t]{3}{*}{ Spel gedrag } & Dartelen/springen & $\mathrm{D}$ & Kalf rent en/ of komt met 2 of meer poten van de vloer \\
\hline & Bespringen & B & Kalf bespringt een soortgenoot. \\
\hline & Stoten & $\mathrm{V}$ & $\begin{array}{l}\text { Kalf is aan het "vechten" (head-to-head fight of hoornen) } \\
\text { met een ander kalf of het kalf verplaatst of duwt een } \\
\text { ander kalf weg. }\end{array}$ \\
\hline
\end{tabular}

\section{Code DEFINITIE}




\section{Drinkwatervoorziening en gladheid vloer}

Bij 10 hokken per bedrijf is gekeken naar de drinkwatervoorziening (methode, tijdstip en hoeveelheid) en de gladheid van de vloer. Dit laatste is uitgevoerd door de vloer te observeren, de grip op de vloer te voelen en de bewegingsgang van de kalveren te bekijken. Beide protocollen zijn in detail omschreven in bijlage 3.

\section{Reinheid kalveren}

Bij 10 hokken per bedrijf is naast de drinkwatervoorziening en gladheid van de vloer ook naar de reinheid van de kalveren gekeken. Per hok zijn van alle kalveren op individueel niveau bepaalde onderdelen van het lichaam beoordeeld. Steeds is vastgesteld of het bepaalde onderdeel meer of minder dan $50 \%$ bevuild was (zie Bijlage 3 ).

\subsubsection{Slachthuis}

Na elke ronde zijn op het slachthuis 3 organen beoordeeld; de longen, de lebmaag en de pens. Van de longen zijn per bedrijf (koppel) 200 longen beoordeeld, van de lebmaag en pens beide 60 stuks. Longen zijn beoordeeld op beschadigingen door ontstekingen (zowel long- als borstvliesontstekingen). De lebmaag is beoordeeld op de aanwezigheid van lesies (erosies of ulcera = maagzweren) in de lebmaag. Bij de pens is gekeken naar de ontwikkeling van de pens - , de aan- of afwezigheid van plaques en hyperkeratose. Het complete protocol is in Bijlage 4 weergegeven.

\subsection{Rapportage}

Nadat alle waarnemingen van een bedrijf zijn uitgevoerd, zijn de gegevens eerst bewerkt tot eenduidige scores. De klinische observaties op het vleeskalverbedrijf en de uitkomsten van beoordeling van organen op het slachthuis zijn uitgedrukt als prevalenties, d.w.z. \% kalveren (van de steekproef) met een bepaalde klinische afwijking, of \% organen (van de steekproef) met een pathologische afwijking. Bij de berekening van prevalenties voor klinische afwijkingen op het vleeskalverbedrijf is gecorrigeerd voor het gegeven dat, indien aanwezig, alle kalveren in de ziekenboeg aan een klinische inspectie worden onderworpen. Van de resultaten van het gedragsonderzoek wordt het vóórkomen van abnormaal oraal gedrag uitgelicht; de score voor abnomaal oraal gedrag wordt uitgedrukt als \% het aantal scans. De uitkomsten van de waarnemingen zijn vervolgens samengevat in een rapportage en verstuurd naar kalverhouder en adviseur. In de rapportage is een keuze gemaakt voor dié parameters waarvan verwacht werd dat zij de kalverhouder belangrijke informatie over het welzijn van zijn/haar kalveren zouden geven. Er is voor gekozen om in de rapportage het accent te leggen op individuele parameters, gegroepeerd naar onderwerp, en om niet, volgens een in het Welfare Quality ${ }^{\circledR}$ project ontwikkelde rekenmethode, geïntegreerde scores voor Criteria, Principes en het 'overall' niveau van welzijn te rapporteren. Een voorbeeld van een werkelijke - geanonimiseerde - rapportage is in Tabel 4 weergegeven.

Voor een beoordeling van een individuele koppel binnen een bedrijf werd een rapportage gemaakt (zie figuur 3). Naast elke parameter (eerste kolom) stond de bijbehorende score. Deze score werd vergeleken met grenswaarden die waren afgeleid uit data afkomstig van eerder onderzoek in het kader van het Welfare Quality project aan meer dan 220 koppels vleeskalveren (ca. 170 blankvlees, en 50 rosé). Voor het vaststellen van onder- en bovengrenzen zijn de 25 en 75 percentielwaarden uit deze data gebruikt. Met behulp van deze grenswaarden werd getracht om een duiding te geven aan de actuele uitkomsten van de beoordeling van de betreffende koppel in termen van de ernst van het probleem. Scores beneden of, afhankelijk van de parameter, boven de streefwaarde voldeden aan een streefniveau. Scores beneden of, afhankelijk van de parameter, boven de tegenoverliggen de uiterste grenswaarde duidden op een ernstig probleem. Scores tussen onder- en bovengrens duidden in deze systematiek op een gering of matig probleem. Elke actuele score werd voorzien van een kleur, afhankelijk van positie van de betreffende score ten opzichte van de grenswaarden: een groene kleur betekende dat de streefwaarde was behaald, een rode score betekende dat de grenswaarde voor een ernstig probleem was overschreden, en een gele of oranje kleur betekende dat de score zich ergens tussen de onder- en bovengrens bevond. Op deze manier kon een kalverhouder of adviseur direct zien op welke parameters relatief goed en op welke relatief minder goed werd gescoord. Na de eerste 
ronde kon er een vergelijking gemaakt worden met de gemiddelde score van alle andere bedrijven in het onderzoek ('benchmarking'). Daarvoor is na de eerste ronde ook een tweede overzicht meegestuurd met daarin de scores per ronde en de gemiddelde scores van alle andere bedrijven (zie Tabel 5).

Tabel 4 Voorbeeld van een rapportage van uitkomsten van beoordeling één ronde.

\section{Resultaten welzijnsmonitor vleeskalveren}

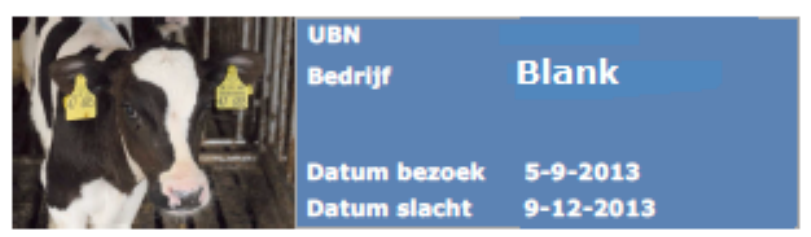

LIVESTOCK RESEARCH WAGENINGEN ER

\section{Staluitrusting}

\begin{tabular}{|c|c|c|c|c|c|c|}
\hline Parameter/berekende data & Uw waarde & Streefwaarde & Gering & & Matig & Ernstig \\
\hline \multicolumn{7}{|l|}{ Watervoorziening } \\
\hline Laagste score uit 10 hokken & 11 & 13 & 12 & 7 & 2 & 1 \\
\hline \multicolumn{7}{|l|}{ Vloeren } \\
\hline Hoogste gladheidscore uit 10 hokken & 4 & 1 & 2 & 4 & 5 & 6 \\
\hline
\end{tabular}

\section{Gezondheid}

\begin{tabular}{|c|c|c|c|c|c|c|}
\hline Parameter/berekende data & Uw waarde & Streefwaarde & Gering & & Matig & Ernstig \\
\hline \multicolumn{7}{|l|}{ Beenwerk: } \\
\hline$\%$ Kreupele kalveren & 0.9 & 0 & 0.1 & 1 & 2 & $>2$ \\
\hline$\%$ Verkregen slijmbeurs & 0.9 & 0 & 0.1 & 2 & 4 & $>4$ \\
\hline \multicolumn{7}{|l|}{ Verwondingen: } \\
\hline$\%$ Aangebeten staart/oor & 0 & 0 & 0.1 & 0.25 & 0.5 & $>0.5$ \\
\hline \multicolumn{7}{|l|}{ Luchtwegen: } \\
\hline$\%$ Hoesten & 4.6 & $<2$ & 2 & 3.6 & 7 & $>7$ \\
\hline$\%$ Afwijkende ademhaling & 1.6 & 0 & 0.1 & 1 & 2 & $>2$ \\
\hline$\%$ Neusuitvloeiing & 0 & $<1$ & 1 & 3 & 6 & $>6$ \\
\hline$\%$ Longen gemiddeld beschadigd & 26 & $<10$ & 10 & 14 & 18 & $>18$ \\
\hline$\%$ Longen ernstig beschadigd & 17.2 & $<3$ & 3 & 10 & 15 & $>15$ \\
\hline$\%$ Longen met pleuritis & 56.8 & $<15$ & 15 & 22.5 & 30 & $>30$ \\
\hline \multicolumn{7}{|l|}{ Vertering: } \\
\hline$\%$ Hokken met dunne mest & 3.6 & 0 & 0.1 & 6 & 12 & $>12$ \\
\hline$\%$ Lesies in de lebmaag & 90 & $<65$ & 65 & 72.5 & 80 & $>80$ \\
\hline$\%$ Plaques in de pens & 43.3 & $<5$ & 5 & 17.5 & 35 & $>35$ \\
\hline$\%$ Hyperkeratose in de pens & 0 & $\leq 1$ & 1.1 & 3.5 & 7 & $>7$ \\
\hline Gemiddelde score pensontwikkeling & 1.6 & $>3.5$ & 3.5 & 2.5 & 1.5 & $<1.5$ \\
\hline $\begin{array}{l}\% \text { Volle kalveren } \\
\text { Algemeen: }\end{array}$ & 3.8 & 0 & 0.1 & 1.5 & 3 & $>3$ \\
\hline$\%$ Dorre kalveren & 0.4 & 0 & 0.1 & 1 & 2 & $>2$ \\
\hline $\begin{array}{l}\% \text { Zieke kalveren } \\
\% \text { Hemoglobinegehalte }<4,5 \mathrm{mmol} / \mathrm{l} \text { : }\end{array}$ & 1.3 & 0 & 0.1 & 0.25 & 0.5 & $>0.5$ \\
\hline * HB laag bij opstart $\rightarrow 13$ wkn & 0.6 & $\leq 3$ & 3.1 & 7 & 9 & $>9$ \\
\hline * HB gemiddeld blj opstart -> 13 wkn & & $\leq 5$ & 5.1 & 9 & 11 & $>11$ \\
\hline * HB verhoogd blj opstart -> 13 wkn & & $\leq 7$ & 7.1 & 11 & 13 & $>13$ \\
\hline * HB hoog bij opstart $->13$ wkn & & $\leq 9$ & 9.1 & 13 & 15 & $>15$ \\
\hline$\%$ Uitval & 3.2 & $\leq 1$ & 1.1 & 1.5 & 3 & $>3$ \\
\hline $\begin{array}{l}\% \text { Kalveren met achterstand in } \\
\text { conditie en gewicht } 15-30 \%\end{array}$ & 1.6 & $<1$ & 1 & 2.5 & 5 & $>5$ \\
\hline $\begin{array}{l}\% \text { Kalveren met achterstand in } \\
\text { conditie en gewicht }>30 \%\end{array}$ & 0 & 0 & 0.1 & 0.5 & 1 & $>1$ \\
\hline$\%$ Bevuilde kalveren & 0 & $<20$ & 20 & 35 & 50 & $>50$ \\
\hline$\%$ Natte kalveren & 0 & 0 & 0.1 & 2.5 & 5 & $>5$ \\
\hline
\end{tabular}

\section{Gedrag kalveren}

\begin{tabular}{|c|c|c|c|c|c|c|}
\hline Parameter/berekende data & Uw waarde & Streefwaarde & Gering & & Matig & Ernstig \\
\hline \multicolumn{7}{|l|}{ Gedrag: } \\
\hline \% Abnormaal oraal gedrag & & $<7$ & 7 & 9 & 18 & $>18$ \\
\hline$\%$ Urine drinkers & 0.4 & 0 & 0.1 & 0.5 & 1 & $>1$ \\
\hline \multicolumn{7}{|l|}{ Gedragstest } \\
\hline$\%$ kalveren aangeraakt & 15.2 & $>22$ & 22 & 14 & 7 & $<7$ \\
\hline
\end{tabular}


Tabel $5 \quad$ Voorbeeld van een totaal overzicht van de resultaten.

\section{Totaal overzicht resultaten welzijnsmonitor}
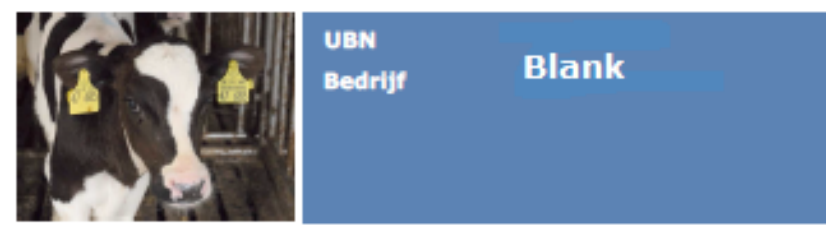

Staluitrusting

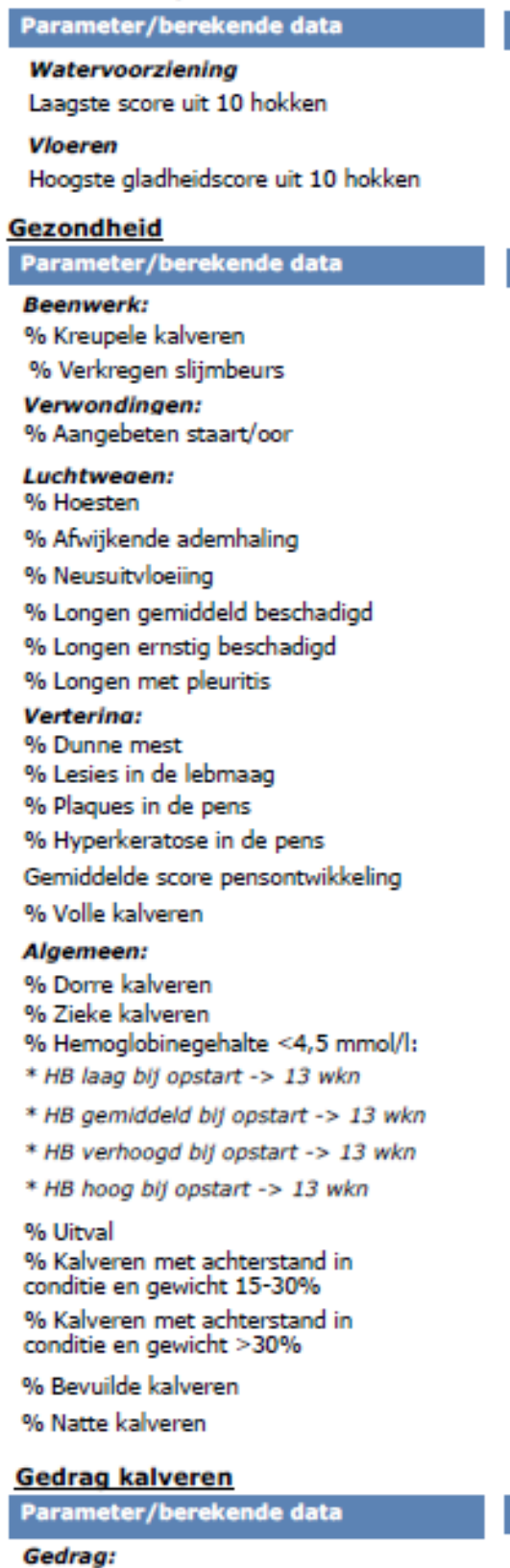

\section{Hoogste gladheidscore uit 10 hokken}
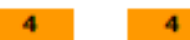

\section{2}

$\%$ Kreupele kalveren

$\%$ Verkregen slijmbeurs

\begin{tabular}{|l|l|}
\hline 0.9 & 2.9 \\
\hline 0.9 & 2.3 \\
\hline
\end{tabular}

0

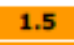

\begin{tabular}{|l|l|}
\hline 2.3 & 2.8 \\
\hline
\end{tabular}

$\%$ Aangebeten staart/oor

$\%$ Dorre kalveren

$\%$ Hemoglobinegehalte $<4,5 \mathrm{mmol} / \mathrm{l}$ :

* HB hoog bij opstart -> 13 wkn

$\%$ Abnormaal oraal gedrag

$\%$ Urine drinkers 


\subsection{Advies/plan van aanpak}

Na ontvangst van de rapportage hebben de kalverhouder en adviseur van het desbetreffende bedrijf de uitslagen besproken en is een advies en plan van aanpak gemaakt aan de hand van een vastgesteld formulier (zie bijlage 5). Deze is naar de onderzoekers opgestuurd. Bij het volgende bezoek van de SKV medewerker is aan de kalverhouder de vraag gesteld wat zij ten opzichte van de ronde ervoor aan hun management veranderd hebben. Op deze manier is zichtbaar geworden of het plan van aanpak ook daadwerkelijk uitgevoerd is.

\section{$2.8 \quad$ Kwantitatieve analyse}

\subsubsection{Uitkomsten training en herexamen van waarnemers}

De beoordelingen van de te trainen waarnemers ('trainees') zijn vergeleken met de beoordelingen van de ervaren waarnemers ('trainers') die als referentie fungeerden. Voorafgaand aan het eerste examen, na afloop van de training, en voorafgaand aan het herexamen werden tijdens intensieve simultaansessies dezelfde dieren respectievelijk organen tegelijkertijd beoordeeld door trainee en trainer. Tussentijds werden de uitkomsten van deze sessies onderling besproken. De examenuitslagen zijn semi-kwantitatief beoordeeld op de mate van overeenkomst tussen trainee en trainer. Alleen op de uitslagen van de beoordelingen van de longen aan de slachtlijn is een meer gedetailleerde kwantitatieve analyse toegepast - daarvoor waren voldoende herhalingen (experimentele eenheden) beschikbaar.

Voor de beoordeling van beschadigingen aan de longen werd een scoringssysteem met vier categorieën gebruikt (zie Bijlage 4). Tijdens het (her)examen beoordeelden de trainee en de trainer naast elkaar, en zonder dat hun scores voor de ander zichtbaar waren, dezelfde 40-50 longen aan de slachtlijn. Er is op vier manieren gekeken naar de mate van overeenkomst tussen de longscores van de trainer en die van de trainee:

a) Er is gekeken naar de nauwkeurigheid waarmee de trainee ernstig aangetaste longen (score 3) kan onderscheiden van longen met een score lager dan 3.

b) $\mathrm{Er}$ is gekeken naar de nauwkeurigheid waarmee de trainee longen met een score van 0 of 1 kan onderscheiden van longen met een score van 2 of 3.

c) $\mathrm{Er}$ is gekeken naar het aantal longen waarvan de longscore van de trainee exact gelijk was aan die van de trainer

d) Er is gekeken naar het aantal longen waarvan de longscore van de trainee maximaal één categorie afweek van die van de trainer (een 1 i.p.v. een 0 , een 0 of een 2 i.p.v. een 1 , of een 2 i.p.v. een 3).

Ad a) Hiervoor is een analyse op sensitiviteit en specificiteit uitgevoerd. De sensitiviteit en de specificiteit worden uitgedrukt als \% tussen 0 en 100. De sensitiviteit heeft betrekking op het aantal longen met score 3 als referentie (toegekend door de trainer) dat ook door de trainee als zodanig is gescoord. Een sensitiviteit van, bijvoorbeeld, $90 \%$ betekent dat de trainee $90 \%$ van de longen met score 3 als referentie ook door de trainee als score 3 zijn aangemerkt. Daaruit volgt dat $10 \%$ van de door de trainee gescoorde longen als 'vals negatief' moeten worden aangemerkt, d.w.z. ten onrechte lager dan 3. De specificiteit heeft betrekking op het aantal longen met een score lager dan 3 als referentie (toegekend door de trainer) dat ook door de trainee als zodanig is gescoord. Een specificiteit van, bijvoorbeeld, $90 \%$ betekent dat de trainee $90 \%$ van de longen met een score lager dan 3 als referentie ook door de trainee als zodanig zijn aangemerkt. Daaruit volgt dat $10 \%$ van de door de trainee gescoorde longen als 'vals positief' moeten worden aangemerkt, d.w.z. ten onrechte een score 3. Naast de sensitiviteit en de specificiteit kan ook het \% longen worden berekend dat door de trainee als 'correct' is geclassificeerd, dus als een score 3 of een score lager dan 3.

Ad b) Hiervoor is eveneens een analyse op sensitiviteit en specificiteit uitgevoerd. In dit geval zijn 'positieve' longen, de longen met een score 2 of 3 als referentie, en 'negatieve' longen, de longen met een score 0 of 1 als referentie. De verdere methodiek is exact gelijk aan die zoals hierboven beschreven. 
Voor de beoordeling van pleuritis werd een scoringssysteem met twee categorieën gebruikt $(0=$ afwezig, 1 = aanwezig, zie Bijlage 4). Voor het analyseren van de mate van overeenstemming tussen trainer en trainee is, net als voor de andere longscore, een analyse op sensitiviteit en specificiteit uitgevoerd, en is gekeken naar het aantal longen waarvan de score voor wat betreft pleuritis van de trainee gelijk was aan die van de trainer.

\subsubsection{Gegevens waarnemingen op bedrijven}

De gegevens die door de SKV waarnemers zijn verzameld aan de hand van systematische waarnemingen op het kalverbedrijf en op het slachthuis zijn samengebracht in een data-base en statistisch geanalyseerd. Daarbij is aan de volgende vijf aspecten aandacht besteed:

a) Het verloop van de scores over de vier opeenvolgende rondes. Een belangrijke vraag daarbij was of in de loop van het project sprake was van een afname van het niveau van welzijnsproblemen.

b) Effecten van seizoen op de uitkomsten van de welzijnsmonitor.

c) Verbanden tussen verschillende rondes - consistentie van verschillen in scores tussen bedrijven. Hierbij was de vraag of bepaalde problemen consistent meer voorkwamen om bepaalde bedrijven.

d) Relaties tussen verschillende variabelen die zijn gemeten, in het bijzonder met betrekking tot luchtwegproblemen.

e) Verschillen tussen blankvleeskalveren en rosékalveren in de waargenomen dierkenmerken.

Ad a) en b) Niveau-verschillen tussen rondes en de effecten van seizoen zijn geanalyseerd met een geneneraliseerd lineair mixed model (GLMM) met fixed effecten Ronde en Seizoen, de interactie tussen Ronde en Seizoen, en met een random effect voor Bedrijf. De random term zorgt ervoor dat rekening wordt gehouden met afhankelijkheid van herhaalde waarnemingen (tijdens opeenvolgende rondes) op hetzelfde bedrijf. De factor Ronde had vier niveau's (respectievelijk ronde $1 \mathrm{t} / \mathrm{m} \mathrm{4}$ ), en de factor Seizoen had ook vier niveau's: 1 = lente, 2 = zomer, 3 = herfst, en 4 = winter, met de onderverdeling in seizoenen op basis van de astronomische indeling. Bij de analyse van de klinische en gedragswaarnemingen correspondeerde het seizoen met het seizoen waarin de waarneming op het kalverbedrijf plaatsvond. Bij de analyse van de pathologische waarnemingen correspondeerde het seizoen met het seizoen waarin de beoodeling van organen aan de slachtlijn plaatsvond. In het model voor de analyse van percentages (tussen 0 en 100) was een logit link gespecificeerd, en werd de variantiefunctie van de binomiale verdeling met een overdispersie parameter geïntroduceerd. Voor het schatten van fixed effecten werd gebruik gemaakt van de F-toets volgens de benadering van Kenward en Rogers (1997). Paarsgewijze verschillen tussen rondes en tussen seizoenen zijn getoetst met behulp van Fisher's Least Significant Difference (LSD) methode.

Ad c) Verbanden tussen rondes zijn op twee manieren geanalyseerd. In de eerste plaats is gebruik gemaakt van een parametervrije methode, namelijk de zogenaamde Spearman Rangcorrelatie toets. De uitkomst van deze toets is een zogenaamde rangcorrelatie. Een significant positieve rangcorrelatie tussen twee rondes voor een bepaalde score (bijvoorbeeld het \% achterblijvers) wil zeggen dat vleeskalverbedrijven met relatief veel achterblijvers tijdens de ene ronde ook relatief veel achterblijvers hebben tijdens de andere ronde, en omgekeerd. Hoge positieve rangcorrelaties zijn een aanwijzing voor het bestaan van bedrijfseffecten op kenmerken die als onderdeel van de welzijnsmonitor worden gemeten. Daarnaast zijn met hetzelfde model als gebruikt voor de schatting van de effecten van Ronde en Seizoen - het GLMM, zie hierboven Ad a) en b) - variantiecomponenten voor Bedrijf geschat. Hoe hoger de waarde van deze component, hoe groter de invloed van bedrijf, en omgekeerd.

Ad d) Relaties tussen clusters van variabelen gerelateerd aan luchtwegproblemen zijn geanalyseerd met behulp van principale componenten analyse (PCA). Met behulp van PCA worden onderling gecorreleerde variabelen samengevat in een beperkt aantal nieuwe variabelen - zogenaamde principale componenten - die lineaire combinaties zijn van de oorspronkelijke variabelen. Principale componenten reflecteren onafhankelijke onderliggende eigenschappen of mechanismen die van invloed zijn op meerdere variabelen tegelijk. PCA genereert per principale component voor elke variabele een zogenaamde 'loading' die fungeert als coëfficient van de lineaire vergelijking. Variabelen 
met hoge loadings ( $>0.50$ ) op dezelfde component en met hetzelfde teken zijn onderling positief geassocieerd, en zijn positief gecorreleerd met de onderliggende eigenschap of het onderliggende mechanisme. In de hier uitgevoerde PCA is specifiek gekeken of klinische variabelen gerelateerd aan luchtwegproblemen en waargenomen bij het levende kalf tijdens de klinische inspectie op het vleeskalverbedrijf (i.c. abnormale ademhaling, neusuivloeiing en hoesten) gerelateerd waren met pathologische kenmerken gerelateerd aan luchtwegproblemen die zijn waargenomen op het slachthuis (i.c. ernstig aangetaste longen en pleuritis). Als input van de PCA fungeerden gegevens van alle rondes.

Ad e) Verschillen in niveau's van variabelen (dierkenmerken) tussen blankvleeskalveren en rosékalveren zijn statistisch geanalyseerd met een gegeneraliseerd lineair model met een fixed effect voor type vleeskalfbedrijf (blank versus rosé). In het model voor de analyse van percentages (tussen 0 en 100) was een logit link gespecificeerd, en werd de variantiefunctie van de binomiale verdeling met een overdispersie parameter geïntroduceerd. Voor variabelen met veel nullen (en lage gemiddelde niveau's) is een parametervrije toets gebruikt voor de analyse van verschillen tussen blankvleesbedrijven en rosébedrijven, de zogenaamde Mann Whitney $U$ test. Als invoer voor deze analyses fungeerden gemiddelde waarden berekend over de vier rondes voor elke variabele binnen elk bedrijf.

Alle statistische analyse zijn uitgevoerd met het statistische programme Genstat (Genstat Committee, 2000).

\subsection{Meningen kalverhouders en adviseurs}

De meningen van kalverhouders over de welzijnsmonitor zijn op twee manieren gepijld. Door Van Hall Larenstein zijn in totaal 21 kalverhouders die aan het project deelnamen één op één op hun bedrijf geïnterviewd. Daarnaast zijn in totaal drie bijeenkomsten georganiseerd met deelnemende kalverhouders en hun adviseurs, met een programma waarin ruimte was voor zowel de uitwisseling van informatie als voor discussie. Tijdens de laatste bijeenkomst waren ook meerdere vertegenwoordigers van de integraties aanwezig.

Tenslotte zijn ook informatie-bijeenkomsten op het slachthuis georganiseerd, zowel voor deelnemende kalverhouders als voor adviseurs en vertegenwoordigers van de integraties, waarbij het pathologie protocol werd uitgelegd, en het scoren van organen 'live' werd gedemonstreerd met echte organen.

\subsection{Communicatie}

Er is op verschillende manieren over het project gecommuniceerd:

- Kalverhouders en hun adviseurs zijn uitgebreid geïnformeerd tijdens de eerder genoemde informatie-bijeenkomsten.

- $\quad$ Er is een digitale Nieuwsbrief uitgebracht die verspreid is onder een groot aantal kalverhouders.

- Er zijn twee artikelen verschenen in de Kalverhouder over de welzijnsmonitor

- Over het project is gerapporteerd tijdens een wetenschappelijk congres. 


\subsection{Vereenvoudiging Welfare Quality ${ }^{\circledR}$ protocollen}

Met behulp van alle beschikbare gegevens van de eerste waarnemingsrondes is een definitieve analyse uitgevoerd met betrekking tot de relatie tussen het volledige protocol en het vereenvoudigde protocol. In het volledige protocol worden gedurende in totaal 3 intervallen van 30 minuten, verdeeld over dag, gedragswaarnemingen gedaan: 30 minuten 's ochtends (ochtend), 30 minuten 's middags (middag) en 30 minuten aan het einde van de middag (namiddag). In het vereenvoudigde protocol worden slechts gedurende één periode van 30 minuten gedragswaarnemingen gedaan (ochtend, middag of namiddag). Uit eerder onderzoek is naar voren gekomen dat het percentage abnormaal oraal gedrag berekend over één van de afzonderlijke periodes van 30 minuten (ochtend, middag of namiddag) significant is gecorreleerd met het percentage abnormaal oraal gedrag berekend over de som van de drie periodes van 30 minuten (1,5 uur waarnemingstijd totaal). Deze significante correlatie suggereert dat een waarnemingstijd van 30 minuten zou voldoen, waarmee de totale duur van het protocol (de aanwezigheid op het vleeskalverbedrijf) aanzienlijk zou kunnen worden bekort. Met behulp van de nieuwe gegevens die in het kader van dit project worden verzameld wordt bekeken of deze vereenvoudiging kan worden bevestigd.

Uit de analyse komt naar voren dat het percentage abnormaal oraal gedrag berekend over één van de afzonderlijke periodes van 30 minuten (ochtend, middag of namiddag) significant is gecorreleerd met het percentage abnormaal oraal gedrag berekend over de som van de drie periodes van 30 minuten (1,5 uur waarnemingstijd totaal). De correlaties (Spearman rangcorrelaties) tussen het percentage abnormaal oraal gedrag berekend over de totale waarnemingsperiode van 1,5 uur en het percentage abnormaal oraal gedrag berekend over elke periode van 30 minuten afzonderlijk (ochtend, middag, namiddag) waren, respectievelijk: $0.90,0.89$ en 0.95 ( $P<0.001$ in alle drie de gevallen). Dat betekent dat ook met een beperkte waarnemingstijd van 30 minuten op een zinvolle manier onderscheid gemaakt kan worden tussen bedrijven met relatief veel en bedrijven met relatief weinig abnormaal oraal gedrag.

\subsection{Resultaten training en examen}

\subsubsection{Nauwkeurigheid beoordeling beschadigingen longen}

In tabel 3 staan de uitkomsten van de analyse van de nauwkeurigheid waarmee de trainees beschadigingen van de longen beoordeelden tijdens het examen en tijdens het herexamen. De gegevens hebben betrekking op vier dezelfde SKV waarnemers die zowel aan het examen als aan het herexamen twee jaar later hebben deelgenomen. Tijdens het herexamen nam de specificiteit enigzins af, met name voor wat betreft het onderscheid tussen scoren 0 of 1 ten opzichte van scores 2 of 3 . Dat betekent dat de trainees in de loop van het project blijkbaar wat 'strenger' (meer beschadigingen) waren gaan scoren dan de referentie; longen die door de trainer (referentie) als score 0 of 1 werden beoordeeld kregen van de trainees wat vaker een score 2 of 3. De nauwkeurigheid waarmee trainees longen met score 3 onderscheidden van longen met een lagere score was zowel tijdens het examen als tijdens het herexamen op een aanvaardbaar niveau.

Tijdens het examen waren de scores van de SKV waarnemers gemiddeld bij $82 \%$ van de longen identiek aan de scores van de trainers (referentie), zie Tabel 6. De mate van exacte overeenkomst tussen trainees en trainer was tijdens het herexamen aanzienlijk gezakt, namelijk tot $62 \%$. Wanneer een verschil in score van de trainee ten opzichte van de trainer van maximaal één categorie (één punt) wordt toegestaan, dan stijgt de mate van overeenkomst tijdens zowel het examen als het herexamen tot ruim boven de $90 \%$. Dat betekent dat de SKV waarnemers in de loop van het onderzoek longen weliswaar niet consequent in exact dezelfde categorie plaatsten als de trainers, maar dat ze wel goed in staat bleken om verschillen in niveau van beschadigingen van longen aan de 
slachtlijn op een consistente manier te beoordelen. Dat geldt met grote nauwkeurigheid voor het identificeren van ernstig beschadigde longen (score 3), zoals blijkt uit tabel 6.

De ranges in Tabel 6 en Tabel 7 geven aan dat individuele waarnemers verschillen in de nauwkeurigheid waarmee ze longen aan de slachtlijn beoordelen. Sommige waarnemers bleken op een aantal punten minder goed te presteren tijdens het herexamen dan tijdens het examen, terwijl bij anderen de nauwkeurigheid op peil bleef.

Tabel 6 Nauwkeurigheid waarmee vier SKV waarnemers beschadigingen van longen hebben beoordeeld tijdens het examen aan het begin van het project na afloop van de training, en tijdens het herexamen twee jaar later.

\begin{tabular}{lcccc} 
& \multicolumn{2}{c}{ Score $<3$ versus score 3} & \multicolumn{2}{c}{ Score 0/1 versus score 2/3 } \\
& Examen & Herexamen & \multicolumn{1}{c}{ Examen } & Herexamen \\
\hline Sensitiviteit (\%) & $92^{1}$ & 90 & 99 & 98 \\
& $(75-100)^{2}$ & $(87-91)$ & $(95-100)$ & $(95-100)$ \\
\hline Specificiteit (\%) & 100 & 89 & 84 & 65 \\
& & $(79-96)$ & $(76-88)$ & $(46-94)$ \\
\hline$\%$ correct & 99 & 90 & 88 & 80 \\
& $(98-100)$ & $(86-96)$ & $(85-90)$ & $(68-94)$ \\
\hline
\end{tabular}

${ }^{1}$ Gemiddelde waarde van de vier SKV waarnemers

${ }^{2}$ Range (minimum - maximum)

Tabel 7 Mate van overeenkomst tussen longscores (0, 1, 2 of 3) van SKV waarnemers en longscores van trainers (referentie) tijdens het examen aan het begin van het project na afloop van de training, en tijdens het herexamen twee jaar later.

\begin{tabular}{lcc} 
& Examen & Herexamen \\
$\%$ identiek & $82^{1}$ & 62 \\
& $(68-88)^{2}$ & $(50-82)$ \\
\hline$\%$ niet meer dan één categorie verschil & 98 & 94 \\
& $(95-100)$ & $(88-100)$ \\
\hline
\end{tabular}

${ }^{1}$ Gemiddelde waarde van de vier SKV waarnemers

${ }^{2}$ Range (minimum - maximum)

\subsubsection{Nauwkeurigheid beoordeling pleuritis}

De uitkomsten van de analyse van de nauwkeurigheid waarmee de trainees pleuritis beoordeelden tijdens het examen en tijdens het herexamen staan in Tabel 8. Deze nauwkeurigheid was over het algemeen hoog. Tijdens het herexamen was de gemiddelde specificiteit wat afgenomen (van $90 \%$ naar $82 \%$ ), met name veroorzaakt door één waarnemer die tijdens het herexamen relatief vaak pleuritis scoorde bij longen die door de trainer als vrij van pleuritis waren beoordeeld (meer vals positieven).

Tabel $8 \quad$ Nauwkeurigheid waarmee vier SKV waarnemers pleuritis hebben beoordeeld tijdens het examen aan het begin van het project na afloop van de training, en tijdens het herexamen twee jaar later.

\begin{tabular}{lcc} 
& Examen & Herexamen \\
Sensitiviteit (\%) & $93^{1}$ & 93 \\
& $(89-96)^{2}$ & $(90-95)$ \\
\hline Specificiteit (\%) & 90 & 82 \\
& $(78-100)$ & $(50-100)$ \\
\hline$\%$ identiek & 92 & 91 \\
& $(88-95)$ & $(86-96)$ \\
\hline
\end{tabular}

${ }^{1}$ Gemiddelde waarde van de vier SKV waarnemers

${ }^{2}$ Range (minimum - maximum) 


\subsection{Resultaten waarnemingen}

\subsubsection{Het verloop van scores over rondes en effecten van seizoen}

Gemiddelde niveau's van alle gemeten dierkenmerken tijdens de vier opeenvolgende rondes bij blankvleeskalveren en rosékalveren staan in, respectievelijk, Bijlage 6 en Bijlage 7. Voor wat betreft klinische verschijnselen van luchtwegproblemen die zijn waargenomen op blankvleesbedrijven lijkt er sprake te zijn van een afname, hoewel de gemiddelden tijdens de tweede ronde niet verschilden van die van de eerste ronde. De laagste percentages kalveren met abnormale ademhaling, neusuitvloeiing en hoesten werden waargenomen tijdens de vierde ronde, en deze percentages weken significant af van die van de eerste en de tweede ronde $(P<0.05)$. Datzelfde beeld werd gevonden op rosébedrijven, met uitzondering van het percentage hoesten.

Ook voor de variabele 'percentage dorre kalveren' neemt de gemiddelde prevalenties tijdens de laatste ronde significant af $(P<0.05)$ ten opzichte van die tijdens de eerste twee rondes, zowel op blankvlees- als rosébedrijven.

De pathologische bevindingen laten minder duidelijke en minder grote verschillen zien tussen opeenvolgende rondes dan de klinische verschijnselen aan het levende kalf. Het \% ernstig aangetaste longen bij blankvleeskalveren was tijdens de tweede en de derde ronde gemiddeld hoger dan tijdens de eerste ronde, en nam in de vierde ronde ten opzichte van de eerste ronde met ongeveer $2 \%$ af ( 12 $\%$ in de vierde ronde ten opzichte van $14.2 \%$ in de eerste ronde). Het percentage longen met pleuritis nam over rondes bij blankvleeskalveren wel af, maar was ook in ronde vier nog steeds hoger dan $40 \%$. De prevalentie van plaques in de pens, en het percentage lebmagen met één of meer lesies namen bij blankvleeskalveren in de loop van het experiment toe.

Bij rosékalveren doen zich vergelijkbare bevindingen voor, waarbij ten opzichte van de eerste rondes in de vierde ronde gemiddeld genomen de laagste prevalenties ernstig aangetaste longen en longen en longen met pleuritis, en de hoogste prevalenties van penzen met plaques en lebmagen met lesies werden gevonden. In de vierde ronde waren de prevalenties ernstig aangetaste longen en longen met pleuritis respectievelijk $26 \%$ en $42 \%$, en de prevalenties penzen met plaques en lebmagen met lesies respectievelijk $32 \%$ en $67 \%$.

Niveau's van uitval waren zowel voor blankvlees- als voor rosébedrijven redelijk constant over rondes heen (rond de $4 \%$ op blankvleesbedrijven, en rond de $3 \%$ op rosébedrijven).

Zowel bij blankvlees- als bij rosékalveren werden de prevalenties kalveren met abnormale ademhaling (duidend op een luchtwegprobleem) en longen met pleuritis significant door seizoen beïnvloed. De hoogste prevalenties kalveren met abnormale ademhaling werden gezien wanneer de klinische beoordeling in de herfst (bij blankvleeskalveren) of in de winter (bij rosékalveren) plaatsvond. De hoogste prevalenties longen met pleuritis werden gezien bij koppels die in de winter waren opgezet.

\subsubsection{Verbanden tussen verschillende rondes}

Uit de analyse kwam naar voren dat voor bepaalde variabelen duidelijke correlaties tussen rondes aanwezig waren en voor andere variabelen niet. Voor elk gemeten kenmerk zijn in totaal zes rangcorrelaties uitgerekend en getoetst: (i) tussen ronde 1 en ronde 2, (ii) tussen ronde 1 en ronde 3, (iii) tussen ronde 1 en ronde 4, (iv) tussen ronde 2 en ronde 3, (v) tussen ronde 2 en ronde 4, en (vi) tussen ronde 3 en ronde 4 .

Per variabele werd gekeken hoeveel van de in totaal zes mogelijke correlaties statistisch significant waren. Om een duidelijk onderscheid te maken werden variabelen aan de hand van de volgende, arbitraire criteria onderverdeeld. Wanneer meer dan vier correlaties significant waren, dan werd een variabele als consistent beschouwd. Wanneer meer dan vier correlaties niet significant waren, dan werd een variabele als niet consistent beschouwd. Consistente en niet consistente variabelen staan in Tabel 9. 


\begin{tabular}{|c|c|c|c|}
\hline \multicolumn{2}{|c|}{ Blank } & \multicolumn{2}{|c|}{ Rosé } \\
\hline Consistent & Niet consistent & Consistent & Niet consistent \\
\hline$\%$ Kalveren aangeraakt & $\%$ Neusuitvloeiing & \% Kalveren aangeraakt & $\%$ Neusuitvloeiing \\
\hline$\%$ Achterblijvers & \% Hoesten & & $\%$ Hoesten \\
\hline$\%$ Plaques & \% Volle kalveren & & \% Volle kalveren \\
\hline \multirow[t]{9}{*}{ Pensontwikkeling } & $\%$ Natte kalveren & & $\%$ Natte kalveren \\
\hline & $\%$ Pleuritis & & $\%$ Pleuritis \\
\hline & \% Lesies lebmaag & & \% Lesies lebmaag \\
\hline & & & \% Dikke knieën \\
\hline & & & $\%$ Achterblijvers \\
\hline & & & $\%$ Muiters \\
\hline & & & \% Zieke kalveren \\
\hline & & & $\begin{array}{l}\% \text { Hokken met dunne } \\
\text { mest }\end{array}$ \\
\hline & & & $\%$ Plaques \\
\hline
\end{tabular}

Bij zowel blankvlees- als rosékalveren was de reactie van kalveren op de mens bijzonder consistent over rondes heen (in beide gevallen waren alle 6 rangcorrelaties statistisch significant). Bij blankvleeskalveren waren ook alle 6 rangcorrelaties statistisch significant voor het percentage achterblijvers. Bij consistente variabelen is sprake van een relatief grote invloed van het bedrijf; bij niet consistente variabelen is de invloed van het bedrijf relatief gering, en is blijkbaar sprake van een aanzienlijke bedrijfsonafhankelijke variatie tussen opeenvolgende koppels.

Opvallend is verder dat twee klinische kenmerken (neusuivloeiing en hoesten) en één pathologisch kenmerk voor luchtwegaandoeningen (pleuritis) duidelijk niet consistent waren, zowel bij blankvleeskalveren als bij rosékalveren. Ook het percentage ernstig aangetaste longen was niet erg consistent - bij zowel blankvees- als rosékalveren waren vier van de 6 rangcorrelaties niet significant. Dit betekent dat de invloed van het bedrijf op luchtwegproblemen bij vleeskalveren waarschijnlijk minder groot was dan de invloed van de individuele koppel binnen ronde.

Bij blankvleeskalveren waren naast het percentage kalveren dat aangeraakt kon worden nog twee andere variabelen consistent: plaques en de pensontwikkeling. Deze variabelen waren niet consistent bij rosékalveren.

Een laatste obervatie die op basis van Tabel 3 gemaakt kan worden is het gegeven dat bij rosékalveren ten opzichte van blankvleeskalveren twee keer zoveel variabelen niet consistent waren.

De uitkomst van de schatting van variantiecomponenten voor Bedrijf ondersteunden volledig het beeld op grond van de rangcorrelaties. Variantiecomponenten voor consistente variabelen waren ruim twee tot drie keer zo groot als variantiecomponeten voor niet consistente variabelen. 


\subsubsection{Relaties tussen variabelen}

In Figuur 2 staat grafisch weergegeven in een zogenaamde biplot het resultaat van de PCA Op gegevens van blankvleesbedrijven.

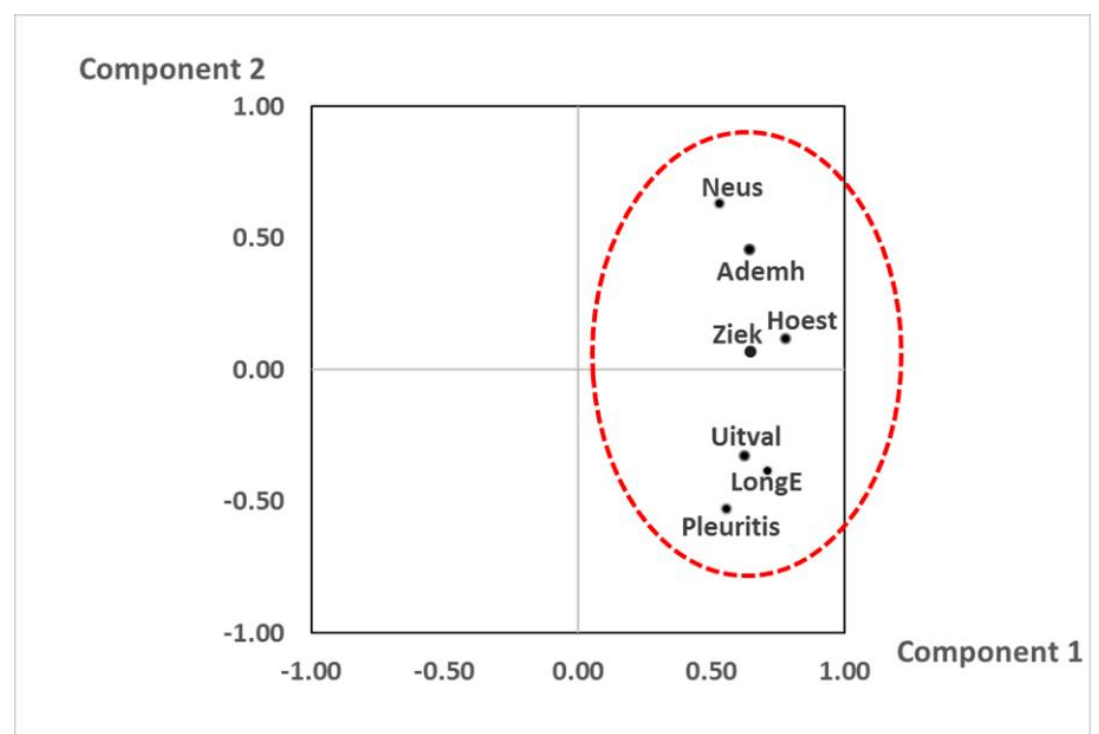

Figuur 2 Verdeling in relatie tot de eerste twee principale componenten verkregen na PCA van klinische en pathologische variabelen indicatief voor luchtwegaandoeningen, plus het percentage zieke kalveren en de uitval. De 'loadings' van elke variabele op de eerste en tweede component fungeren als coördinaten op, respecievelijk, de horizontale en vertikale as. Omschrijving variabelen: Ademh $=\%$ kalveren met abnormale ademhaling, Neus = \% kalveren met neusuitvloeiing, Hoest $=\%$ hoesten, LongE $=\%$ ernstig aangetaste longen, Pleuritis = \% longen met pleuritis, en Uitval $=\%$ uitval.

De eerst principale component verklaarde $42 \%$ van de variantie (Eigenvalue 2.9), en had hoge loadings voor de variabelen die in Figuur 2 zijn omcirkeld door rode stippellijnen. In Figuur 2 heeft de gestippelde ovaal rechts betrekking op variabelen met een hoge positieve loading $(>0.50)$ op de eerste principale component. Dit patroon geeft aan dat al deze variabelen onderling positief gecorreleerd zijn. Bij koppels waar na slachting veel beschadigingen in de longen werden gezien waren eerder op het vleeskalverbedrijf ook veel klinische verschijnselen van luchtwegaandoeningen waargenomen. Bij deze koppels was ook sprake van relatief veel zieke kalveren, en een hoge uitval.

Eenzelfde figuur, Figuur 3, is ook gemaakt van de resultaten van de PCA op gegevens afkomstig van rosébedrijven. Dezelfde variabelen als die bij blankvleeskalveren zijn als input gebruikt. Hier verklaarde de eerste principale component 35\% van de variantie (Eigenvalue 2.5).

Uit Figuur 3 komt naar voren dat het loadingpatroon bij rosékalveren bijna indentiek was aan het loadingpatroon bij blankvleeskalveren. Met uitzondering van het \% uitval vormen dezelfde variabelen een cluster (in de figuur omcirkeld door de rode stippellijn) die wordt gekarakteriseerd door hoge loadings op de eerste principale component. Net als bij blankvleeskalveren zijn ook bij rosékalveren klinische en pathologische verschijnselen van luchtwegaandoeningen onderling positief gecorreleerd. 
Component 2

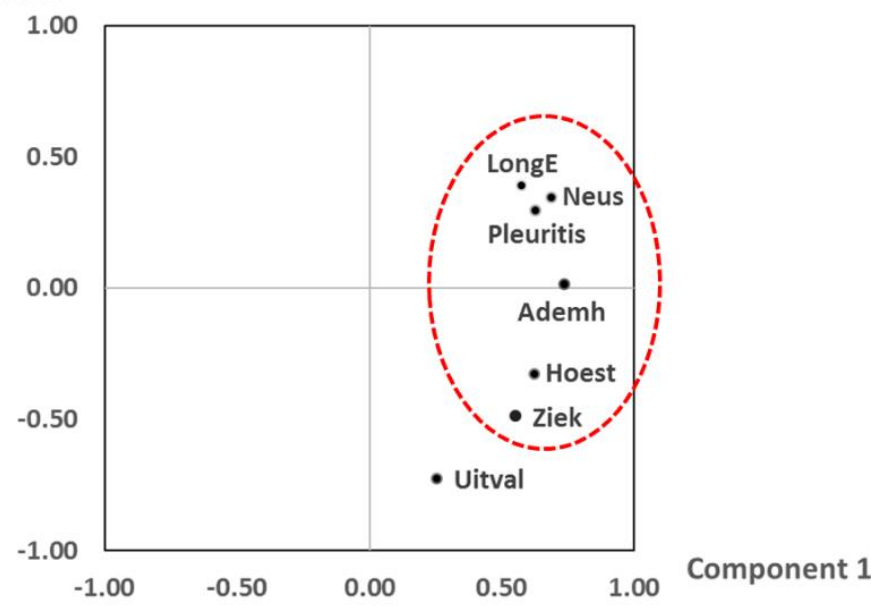

Figuur 3 Voor onderschrift zie Figuur 2.

\subsubsection{Verschil tussen rose en blank}

De verschillen tussen blankvlees- en rosékalveren staan in Tabel 10.

Tabel 10 Gemiddelden en standaardfout (SE) van vier opeenvolgende mestrondes van dierkenmerken uit de welzijnsmonitor, en het effect van type vleeskalverhouderij (blank versus rosé) op die kenmerken.

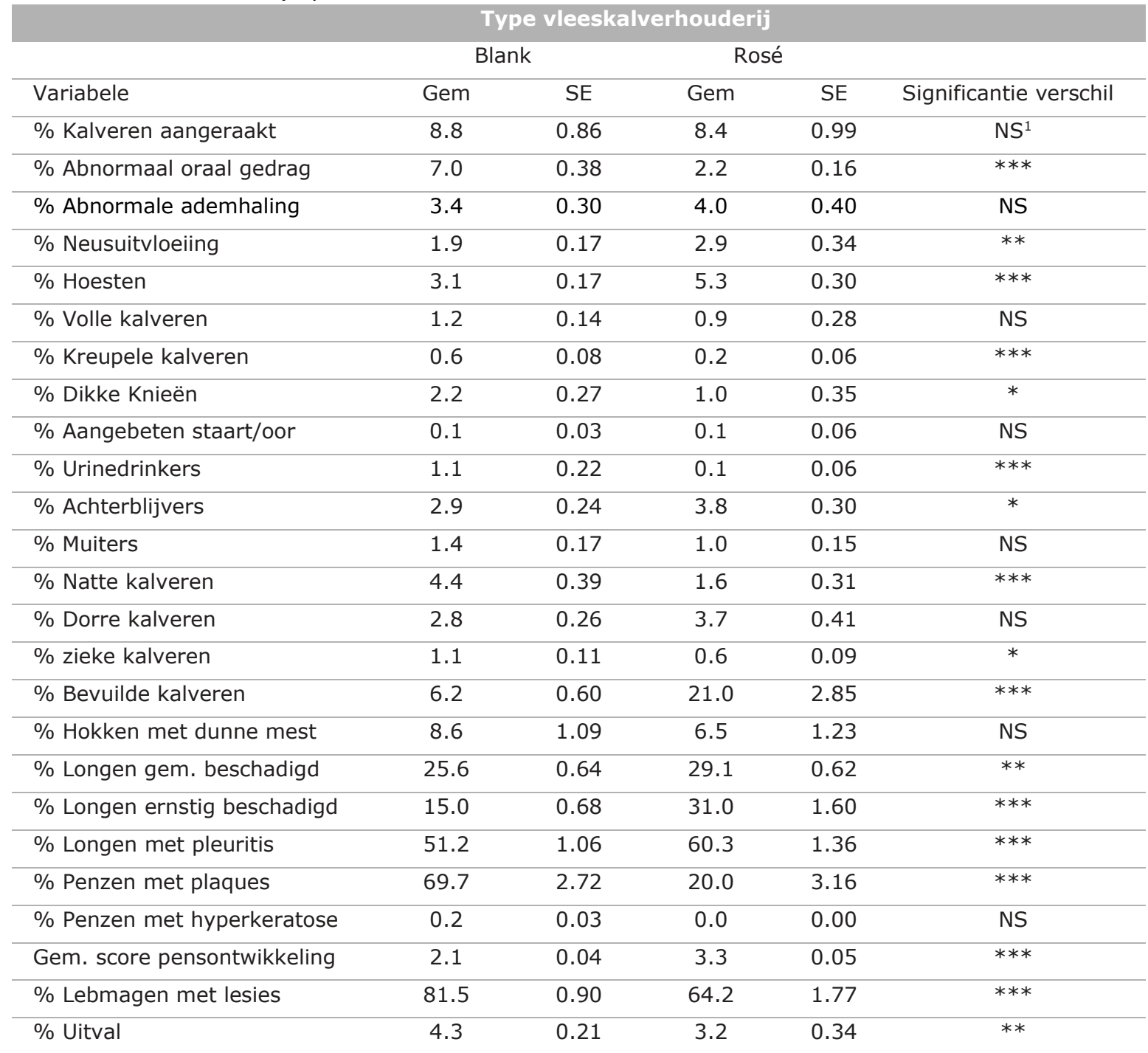

${ }^{1} \mathrm{NS}$ : niet significant; $* P<0.05 ; * * P<0.01 ; * * * P<0.001$ 
Voor het analyseren van de verschillen tussen blankvlees- en rosébedrijven zijn eerst voor elk bedrijf en voor elk kenmerk gemiddelden over de vier rondes berekend. Uit Tabel 10 komt naar voren dat blankvleeskalveren ten opzichte van rosékalveren over het algemeen minder luchtwegproblemen laten zien (lagere prevalenties neusuitvloeiing en hoesten; lagere prevalenties ernstig aangetaste longen en longen met pleuritis), en juist meer afwijkingen aan pens en lebmaag (hogere prevalenties penzen met plaques en lebmagen met lesies).

\subsection{Praktische toepasbaarheid van het Welfare Quality ${ }^{\circledR}$ protocol voor vleeskalveren}

Het Welfare Quality $®$ protocol was in principe goed toepasbaar in de praktijk. Een belangrijke voorwaarde voor de praktische toepasbaarheid was de mogelijkheid om waarnemers te trainen die zelf niet direct bij de ontwikkeling van het protocol betrokken waren geweest of als dierenarts of veterinair patholoog waren geschoold. In het huidige project zijn buitendienst medewerkers van SKV succesvol opgeleid tot waarnemer, en zijn de waarnemingen op vleeskalverbedrijven en slachthuizen vervolgens naar behoren uitgevoerd. Uit het herexamen van de waarnemers kwam naar voren dat de nauwkeurigheid van waarnemers in de loop van het project wel wat was afgenomen als het gaat om de beoordeling van longen. De SKV waarnemers leken in de loop van het project wat 'strenger' te zijn geworden dan de trainers, in de zin dat beschadigingen als ernstiger werden beoordeeld, en hadden meer moeite om longen in exact dezelfde categorie te plaatsen als de trainers. Niettemin was de afwijking tussen de longscores toegekend door SKV waarnemers en de longscores door de trainers doorgaans niet meer dan één punt, en bleken SKV waarnemers ook tijdens het herexamen redelijk goed in staat om ernstig aangetaste longen te onderscheiden van minder aangetaste longen. De uitvoering van het protocol was tijdrovend, en vergde gedurende de looptijd van het project een vrijwel continue personele inzet van waarnemers van SKV. Het coördineren en inplannen van de waarnemingen, ook zodanig dat de juiste koppels kalveren niet alleen op het vleeskalverbedrijf maar ook op het slachthuis werden beoordeeld, is zonder problemen verlopen. Dit was, gelet op de specifieke expertise van de SKV, in dit project in uitstekende handen.

\subsection{Adviezen aan kalverhouders}

\subsubsection{Binnenkomst adviezen}

In totaal zijn 256 rapportages naar de kalverhouders en adviseurs toegestuurd. Hiervan zijn uiteindelijk 97 adviezen van adviseurs terug ontvangen. Dit is ongeveer $38 \%$. In de startfase van het project waren nog niet alle adviseurs in beeld en hadden niet alle adviseurs de bijeenkomsten bijgewoond. Hierdoor kwam de binnenkomst van adviezen later op gang, waardoor er weinig adviezen naar aanleiding van de eerste ronde ontvangen zijn (30 adviezen in totaal). Maar ook later bleek het lastig om de adviseurs zover te krijgen dat ze met de rapportage aan de slag zijn gegaan. Ronde 2 leverde 34 adviezen op en ronde 3 en 4 slechts respectievelijk 18 en 15 adviezen. Om meer adviezen van de adviseurs te ontvangen zijn in eerste instantie via email herinneringen naar de adviseurs gestuurd en als laatste zijn de adviseurs telefonisch benaderd. Dit heeft er uiteindelijk niet voor gezorgd dat er meer adviezen binnenkwamen.

\subsubsection{Inhoud adviezen}

Het formulier voor de adviseur (Bijlage 5) bevat een deel voor algemene conclusies en een deel voor een concreet plan van aanpak. Van alle binnengekomen adviesformulieren is bij elk plan van aanpak gekeken op welk onderdeel van de welzijnsmonitor deze betrekking heeft en wat voor deeladvies ter verbetering daarvoor gegeven is. In Bijlage 8 zijn alle deeladviezen weergegeven. Het blijkt dat er vooral adviezen met betrekking tot longaandoeningen ( $82 \mathrm{keer}$ ) en plaques in de pens ( 35 keer) gegeven zijn. Daarnaast is ook veel aandacht besteed aan diarree, pensverzuring (als veronderstelde oorzaak van de met de welzijnsmonitor waargenomen afwijkingen) en de verteringsproblematiek. De adviezen waren zeer divers, en door verschillende adviseurs zijn voor hetzelfde probleem een veelheid aan adviezen gegeven. 


\subsubsection{Opvolging en effect van adviezen}

Om het eventuele effect van de adviezen in kaart te brengen hebben SKV-waarnemers bij elk volgende bezoek aan de kalverhouder gevraagd of er zaken op het bedrijf zijn aangepast. In Bijlage 9 is een overzicht van deze aanpassingen gerubriceerd op onderdeel weergegeven.

Als de adviezen van de adviseur naast de door de kalverhouder genoemde aanpassingen worden gelegd, dan blijkt dat van de 222 gegeven deeladviezen 30 daarvan precies zijn opgevolgd. Het valt op dat kalverhouders vaak ook andere aanpassingen melden dan voorgesteld door de adviseur, en dat kalverhouders ook regelmatig aangeven niets veranderd te hebben.

Uiteindelijk is van slechts 6 kalverbedrijven na afloop van elke ronde een volledig advies ontvangen. In bijlage 10 is een overzicht gegeven van de deeladviezen die op deze 6 bedrijven ( $\mathrm{At} / \mathrm{m} \mathrm{F}$ ) zijn gegeven, welke maatregelen zijn genomen, en wat het effect van de uitgebrachte deeladviezen is geweest op de uitkomsten van de welzijnsmonitor tijdens de daaropvolgende ronde. De deeladviezen en maatregelen waren zeer divers, en de effecten in termen van de uitkomsten van de welzijnsmonitor lijken soms positief, soms neutraal en soms negatief. Om een indruk te krijgen van de aard en reikwijdte van de deeladviezen en maatregelen op een zestal vleeskalverbedrijven is bijlage 9 informatief. Deze gegevens zijn echter veel te beperkt van omvang om verbanden te kunnen leggen tussen adviezen, maatregelen en uitkomsten van de welzijnmonitor.

\subsubsection{Meningen van kalverhouders en adviseurs over de welzijnsmonitor}

De meningen van de deelnemende kalverhouders over de welzijnsmonitor waren zeer uiteenlopend, van positief tot neutraal tot negatief.

Een aantal voorbeelden van uiteenlopende en illustratieve citaten uit gesprekken met kalverhouders:

"De uitkomst van de welzijnsmonitor bevestigen de problemen op dit bedrijf. Het aantal kalveren met klinische longproblemen en het aantal doffe kalveren zijn het gevolg van de Mannheimia infectie die op dit bedrijf speelt."

"Monitor geeft goed het beeld weer van wat we ook in de stal ervaren. Deze ronde beduidend meer dunne mest: coccidiose gehad. Luchtwegen slachtlijn stuk beter. Blijft natuurlijk dramatisch. Zijn er bedrijven die de streefwaarde halen?"

"Verschillende parameters scoren duidelijk beter dan het gemiddelde. Echter gezien de inspanningen, de genomen maatregelen, en het beeld op het bedrijf, passen de gezondheids parameters hier niet bij."

"Longafwijkingen in het rood vinden we raar, er zijn deze ronde geen problemen mee geweest."

De oorspronkelijke wijze van presentatie van de uitkomsten (zie Figuren 3 en 4) werd over het algemeen als niet erg stimulerend ervaren. Dan ging het met name om de kleuren; het bleek dat erg veel scores in het "rode" gebied uitkwamen. Dit gaf toch vaak het gevoel dat niet slechts zakelijk over de situatie op het bedrijf werd gerapporteerd, maar dat een soort van "rode kaart" werd uitgedeeld.

Aan dit punt van kritiek is getracht tegemoet te komen door ook een andere wijze van presenteren van de uitkomsten van de welzijnsmonitor aan de deelnemers voor te leggen. Het accent ligt dat niet zozeer op de vergelijking van de eigen scores met een normatief kader (streefwaarden e.d.), maar veel meer op de (vooral visuele) vergelijking van de eigen score met de scores van andere bedrijven (benchmarking). Een voorbeeld van deze wijze van presenteren van een individuele parameters, in dit geval het \% ernstig aangetaste longen, staat in Figuur 4. Deze wijze van presenteren werd door de meeste deelnemers als illustratiever ervaren. 


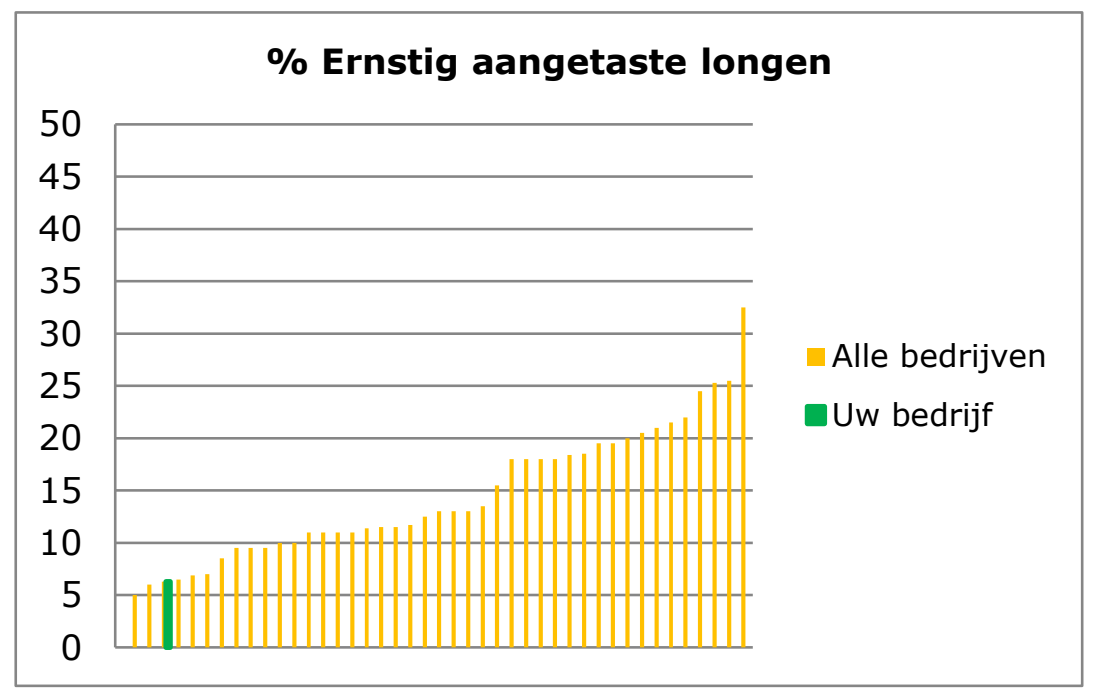

Figuur 4 Alternatieve wijze van presenteren van een individuele parameters uit de welzijnsmonitor - in dit geval het \% ernstig aangetaste longen.

Een andere opmerking van de deelnemende kalverhouders had betrekking op de mate van invloed die zij feitelijk kunnen uitoefenen op de gezondheid van hun kalveren. Veel deelnemende kalverhouders gaven aan dat belangrijke factoren die van invloed zijn op de gezondheid van vleeskalveren zich voor een groot deel buiten hun invloedssfeer bevinden. Daarbij werd vooral gedoeld op de kwaliteit van de kalveren bij opzetten, en (m.n. voor blankvlees) de kwaliteit van het rantsoen (kalvermelk en ruw- en krachtvoer). Daardoor was het gevoel bij sommige deelnemers dat de kalverhouder maar in beperkte mate sturingsmogelijkheden heeft om veranderingen en verbeteringen qua gezondheid en welzijn van de kalveren door te voeren. De gedachte dat het verbeteren van de gezondheid van vleeskalveren een verantwoordelijkheid is van de keten, en niet alleen van de individuele kalverhouder, werd breed gedeeld.

Tenslotte merkten deelnemende kalverhouders op dat er eigenlijk ook andere informatie in de rapportage over de uitkomsten van de welzijnsmonitor opgenomen zou moeten worden, bijvoorbeeld ten aanzien van het rantsoen, de herkomst en de kwaliteit van de kalveren, de technische resultaten en het gebruik van antibiotica. Daarmee zou een completer beeld van een koppel kalveren worden verkregen en zou wellicht een beter advies gegeven kunnen worden over maatregelen die genomen zouden kunnen worden om de gezondheid van de kalveren te verbeteren.

De adviseurs - voor zover aanwezig op informatie- en demonstratiebijeenkomsten (zie 3.6.1) - lieten een vergelijkbare diversiteit aan opvattingen over de welzijnsmonitor zien als kalverhouders. Sommige adviseurs raakten tijdens het project overtuigd van de meerwaarde van met name de gegevens over de gezondheid van de kalveren uit de welzijnsmonitor; bij anderen was dat veel minder het geval.

\subsection{Kennisverspreiding}

Deelnemende kalverhouders en adviseurs zijn drie keer uitgenodigd voor een informatiebijeenkomst: één aan het begin van het project, één halverwege het project, en één aan het eind van het project (slotbijeenkomst). Tijdens deze bijeenkomsten werden de welzijnsmonitor en de opzet van het project toegelicht, en werden de uitkomsten, adviezen en resultaten besproken en gepresenteerd (zie figuur 7). Ongeveer $25 \%$ van zowel kalverhouders als adviseurs heeft tenminste één van de informatiebijeenkomsten bezocht. 

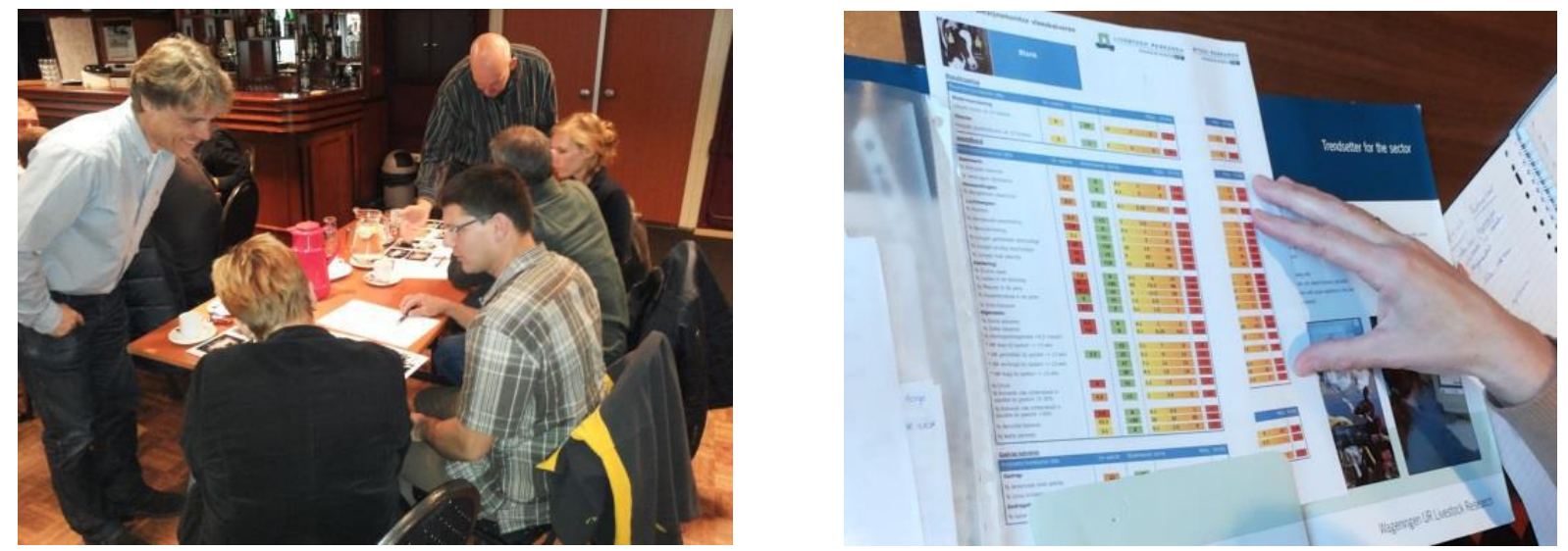

Figuur 7 Impressie van een informatiebijeenkomst met kalverhouders.

Naast informatiebijeenkomsten zijn ook twee demonstratiebijeenkomsten georganiseerd op het slachthuis voor kalverhouders en adviseurs, waarbij de beoordeling van longen, pensen en lebmagen is uitgelegd door de veterinair pathoog van Wageningen UR (zie figuur 8). Dit was voor de deelnemers uitermate verhelderend, en werd zeer positief ontvangen. Daar waar bij sommige deelnemers enige scepsis bestond over de waarde van de uitkomsten van het onderzoek aan organen, groeide het vertrouwen in de waarde van het pathologie protocol aanzienlijk na deelname aan de demonstratiebijeenkomst.
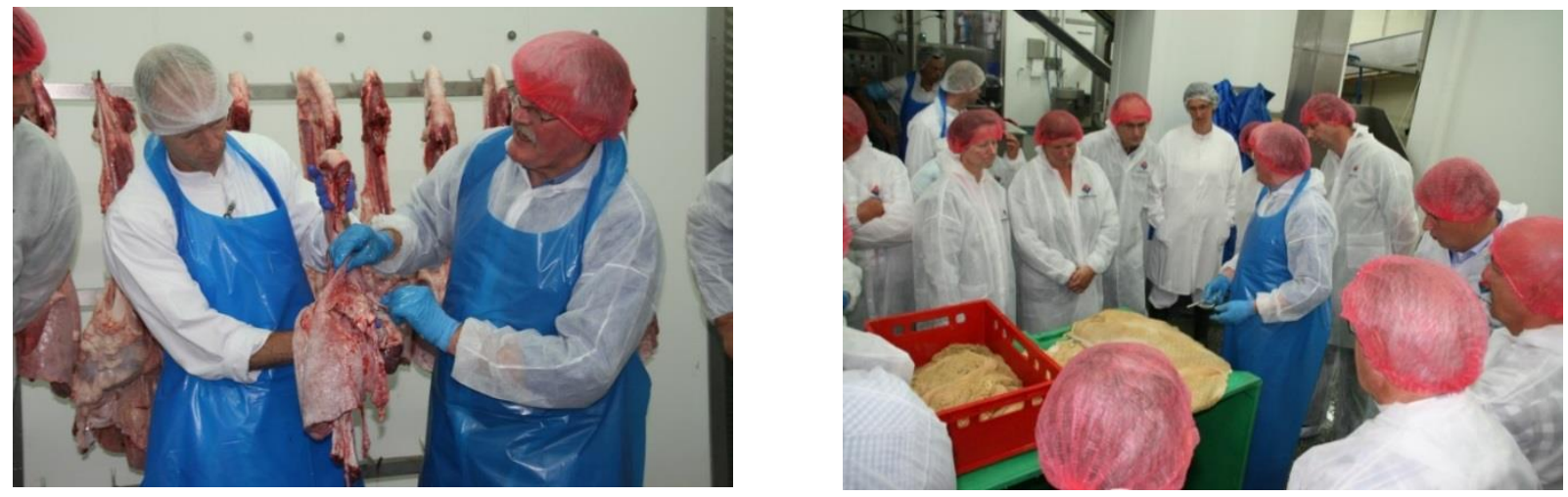

Figuur 8 Impressie van een demonstratiebijeenkomst met kalverhouders op het slachthuis.

Door Van Hall Larenstein is een drietal nieuwsbrieven gemaakt over het project. De nieuwsbrieven zijn per email verspreid onder de deelnemende kalverhouders en hun adviseurs. En voorbeeld van een Nieuwsbrief staat in Bijlage 11.

Over de welzijnsmonitor zijn twee artikelen verschenen in de Kalverhouder. Daarnaast is over de welzijnsmonitor vleeskalveren gerapporteerd tijdens een wetenschappelijk congres (van Reenen et al., 2015). 


\section{Discussie, conclusies en aanbevelingen}

\subsection{Vereenvoudiging Welfare Quality ${ }^{\circledR}$ protocollen}

De eerder voorgestelde vereenvoudiging om de waarnemingstijd voor de gedragswaarnemingen te beperken (Biometris en Wageningen Livestock Research, 2012) lijkt op basis van de resultaten van het huidige onderzoek zonder meer te verdedigen.

- Dat betekent dat een waarnemingstijd van 30 minuten in plaats van 1,5 uur voldoende is om zinvol onderscheid te maken tussen vleeskalverbedrijven waar relatief veel en vleeskalverbedrijven waar relatief weinig abnornaal oraal gedrag voorkomt.

\subsection{Resultaten warnemingen}

Tussen rondes worden zowel bij blankvlees- als rosékalveren verschillen gezien in gemiddelde scores van verschillende parameters uit de welzijnsmonitor. Voor een groot aantal parameters, met name met betrekking tot luchtwegproblemen, waren de gemiddelde niveau's tijdens de vierde ronde lager dan tijdens de eerste ronde (Bijlagen 6 en 7). Wellicht dat het meedraaien in de beoogde kwaliteitscyclus uiteindelijk toch een zeker positief effect heeft gehad op de gezondheid van vleeskalveren op de deelnemende bedrijven, zonder dat daar duidelijk aanwijsbare maatregelen aan ten grondslag lagen. Op dit punt is voorzichtigheid echter wel geboden. De uitkomsten van de twee examens van de SKV waarnemers zien dat de nauwkeurigheid van de beoordeling van beschadigingen in de longen zich weliswaar op een aanvaardbaar niveau leek te handhaven gedurende het verloop van het project, maar dat er wel sprake was van een verschuiving van accenten ("drift"). Het is niet ondenkbaar dat een bepaalde mate van "drift" - met een vooralsnog onbekende omvang en richting ook van toepassing was op de beoordelingen van de klinische gezondheid van de kalveren op het vleeskalverbedrijf.

Niettemin waren, los van het al of niet aanwezig zijn van significante verschillen in niveau's tussen rondes, zowel bij blankvlees- als rosékalveren de niveau's van lesies in de lebmaag, plaques in de pens, ernstige beschadigingen in de longen en pleuritis tijdens alle rondes in dezelfde orde van grootte. De verschillen in luchtwegproblemen tussen vleeskalverbedrijven, zowel in termen van pathologische afwijkingen na slachting als met betrekking tot het klinische beeld op het vleeskalverbedrijf, waren niet of nauwelijks consistent tussen de verschillende rondes, wat de gedachte ondersteunt dat naast factoren gerelateerd aan het vleeskalverbedrijf, vooral ook factoren gerelateerd aan de individuele koppel (zoals bijvoorbeeld de kwaliteit, herkomst of de omstandigheden op het melkveebedrijf van oorsprong van de kalveren) van invloed zijn op dit type

gezondheidsproblemen. Dat zou eens te meer pleiten voor een ketengerichte aanpak om te komen tot een verbetering van de (luchtweg)gezondheid van vleeskalveren.

- In de vleeskalverhouderij lijkt sprake van een aantal hardnekkige gezondheids- en welzijnsproblemen, waarop voor een belangrijk deel factoren invloed hebben die niet gerelateerd zijn aan het vleeskalverbedrijf. Dit geldt in het bijzonder voor luchtwegproblemen. Dit zou mede kunnen verklaren waarom de (in dit project weliswaar in beperkte mate genomen) maatregelen op een individueel kalverbedrijf op de korte termijn - binnen het bestek van een viertal opeenvolgende mestrondes - niet erg effectief zijn. Deze gegevens zijn relevant wanneer wordt nagedacht over effectieve strategieën ter verbetering van de (luchtweg)gezondheid van vleeskalveren. 
Voor een beperkt aantal variabelen uit de welzijnsmonitor gold dat verschillen tussen bedrijven buitengewoon consistent waren tussen rondes. Voor zowel blankvlees- als rosébedrijven waren alle 6 mogelijke rangcorrelaties tussen rondes statistisch significant voor de uitkomst van de gedragstest waarbij de reactie op van kalveren op benadering door een persoon wordt gemeten. De aanname is dat deze gedragsreactie de mate van angstigheid van kalveren voor mensen reflecteert, en voor een belangrijk deel wordt bepaald door de manier waarop de kalverhouder met zijn/haar dieren omgaat (Bokkers et al., 2009). Daarmee zou deze gedragsreactie een kenmerk van het individuele kalverbedrijf vormen; de gevonden consistentie is hiermee in overeenstemming. Bij blankvleeskalveren waren verder het \% achterblijvers, het \% plaques in de pens, en de pensontwikkeling consistent tussen rondes. Ook voor de verklaring van deze bevindingen ligt het voor de hand om te veronderstellen dat sprake is geweest van duidelijke bedrijfseffecten. Het \% achterblijvers in een hok is in hoge mate de resultante van het gevolgde sorteerbeleid van de individuele kalverhouder. Op rosébedrijven wordt doorgaans veel minder (en in ieder geval veel minder frequent) gesorteerd dan op blankvleesbedrijven. In vergelijking met rosébedrijven wordt op blankvleesbedrijven over het algemeen ook een veel stringentere en constante voerstrategie gehanteerd, zeker daar waar het kalverbedrijven onder contract betreft. Het algemene beeld dat op rosébedrijven ten opzichte van blankvleesbedrijven minder variabelen duidelijk consistent, en meer variabelen duidelijk niet consistent waren, zou erop kunnen wijzen dat de houderijomstandigheden van rosékalveren tussen opeenvolgende rondes en binnen bedrijven wat minder constant zijn dan die van blankvleeskalveren.

Klinische variabelen met betrekking tot luchtwegproblemen en post-mortem geregistreerde afwijkingen aan longen waren onderling gecorreleerd, zowel bij blankvlees- als bij rosékalveren. Dit laat zien dat bij koppels waar rond week 13 op het vleeskalverbedrijf relatief veel klinische luchtwegproblemen waarneembaar waren de longen na slachting eveneens veel beschadigingen en gevallen van pleuritis lieten zien. Deze vinding ondersteunt de validiteit van de gehanteerde protocollen, omdat waarnemingen op het vleeskalverbedrijf en op het slachthuis niet alleen in de tijd ca. 3 maanden uit elkaar lagen, maar ook veelvuldig door verschillende waarnemers werden uitgevoerd. Het is daarom praktisch uitgesloten dat een vooringenomenheid of subjectiviteit van de SKV waarnemers, bijvoorbeeld op grond van bepaalde verwachtingen, aan de gevonden correlatiestructuur ten grondslag heeft gelegen. Dit resultaat suggereert verder dat er soms sprake geweest kan zijn van een bepaalde mate van 'bedrijfsblindheid' waarbij het vóórkomen van klinische luchtwegproblemen niet altijd als zodanig door de kalverhouder of de adviseur werd herkend of gewaardeerd. Het in bepaalde gevallen ontsnappen aan de aandacht van klinische luchtwegproblemen zou ook de reden geweest kunnen zijn van de twijfel die sommige deelnemers uitten ten aanzien van relatief hoge prevalenties beschadigingen aan longen die werden gerapporteerd (zie ook paragraaf 3.5.4). Daarnaast is niet uit te sluiten dat beschadigingen in de longen in incidentele gevallen niet gepaard gaan met (duidelijk) uiterlijk waarneembare klinische verschijnselen. Nader onderzoek, met naast post mortem onderzoek een uitgebreider en frequenter klinisch onderzoek aan levende kalveren, zou op dit punt meer duidelijkheid kunnen verschaffen.

De validiteit van de waarnemingsprotocollen wordt verder ondersteund door de vinding dat rosébedrijven en blankvleesbedrijven significant van elkaar verschillen in niveau's van scores uit de welzijnsmonitor, ondermeer met betrekking tot luchtwegproblemen (hoger in rosékalveren), en plaques in de pens, lesies in de lebmaag en abnormaal oraal gedrag (hoger in blankvleeskalveren). Deze verschillen komen bijna naadloos overeen met de verschillen tussen deze twee typen vleeskalverhouderij zoals die in eerder onderzoek zijn gevonden (Animal Sciences Group van Wageningen UR et al., 2010).

Dergelijke verschillen tussen houderijsystemen zijn ook interessant als het gaat om het identificeren van mogelijke risicofactoren voor gezondheids- en welzijnsproblemen bij vleeskalveren. Wellicht dat, bijvoorbeeld, het doorgaans ontbreken van all-in-all-out bij rosébedrijven, terwijl dit op blankvleesbedrijven gebruikelijk is, mede ten grondslag ligt aan de relatief hoge prevalenties luchtwegproblemen bij rosékalveren. Met de regelmatige aanvoer van nieuwe dieren zouden ook telkens weer nieuwe pathogenen het rosébedrijf binnenkomen, en tot herbesmetting van al aanwezige kalveren kunnen leiden. Het ligt verder voor de hand om te veronderstellen dat hogere prevalenties afwijkingen aan het maagdarmstelsel bij blankvleeskalveren ten opzichte van rosékalveren mede zijn 
terug te voeren op factoren in het rantsoen, bijvoorbeeld op de combinatie van kalvermelk met vast voer. Aan de hand van gericht vervolgonderzoek zouden dit soort hypothesen getoetst kunnen worden.

Opvallend is dat de niveau's voor een aantal variabelen uit de welzijnsmonitor beduidend anders liggen dan in eerder onderzoek (Brscic et al., 2012; Leruste et al., 2014). Dat geldt bijvoorbeeld voor het \% (ernstig) beschadigde longen (aanzienlijk hoger dan eerder gevonden) en het \% abnormaal oraal gedrag bij blankvleeskalveren (aanzienlijk lager dan eerder gevonden). De eerder gerapporteerde cijfers zijn afkomstig van waarnemingen uit de periode 2005 - 2009, dus deze trends zouden in de eerste plaats kunnen wijzen op veranderingen in management en verzorging die sinds die periode in de Nederlandse kalverhouderij zijn opgetreden. Dan zou bijvoorbeeld gedacht kunnen worden aan een gewijzigd antibioticumbeleid waarbij met curatief ingrijpen wellicht langer gewacht wordt waardoor klinische verschijnselen - en daardoor post-mortem waarneembare beschadigingen in de longen - meer om zich heen kunnen grijpen. Een andere belangrijke verandering in de Nederlandse kalverhouderij heeft betrekking op het rantsoen van met name blankvleeskalveren; daarin is de vast voer component enorm toegenomen, zodanig dat veel kalveren momenteel bijna ad lib vast voer (krachtvoerbrok met gehakseld stro) vertrekt krijgen. Op grond van de kennis uit de literatuur zou dit een daling van de prevalentie abnormaal oraal gedrag tot gevolg moeten hebben, en dat is precies wat de uitkomsten van het huidige onderzoek laten zien. Deze veronderstellingen zouden met gericht vervolgonderzoek in de praktijk nader geverifieerd kunnen worden. Naast daadwerkelijke trends in management en verzorging van kalveren zou ook de inzet van andere waarnemers dan voorheen op de nu gevonden absolute niveau's van parameters uit de welzijnsmonitor van invloed geweest kunnen zijn. Vervolgonderzoek zou kunnen uitwijzen in hoeverre dit ook een rol heeft gespeeld.

- De welzijnsprotocollen die in deze praktijkstudie zijn gehanteerd lijken voor een belangrijk deel valide en betrouwbaar, in ieder geval daar waar het de detectie van relatieve verschillen in gezondheids- en welzijnsparameters tussen koppels, tussen bedrijven en tussen systemen (blankvlees versus rosé) betreft.

Voor een tweetal variabelen gerelateerd aan luchtwegproblemen, i.c. abnormale ademhaling en pleuritis, werden significante effecten van seizoen gevonden. De vinding dat post mortem karakteristieken van luchtwegproblemen, zoals pleuritis, zich het meest voordoen bij koppels kalveren die zijn opgezet in de winter komt overeen met de resultaten van Brscic et al (2011). Dit betekent dat voor een eerlijke vergelijking tussen bedrijven - met name op het punt van luchtwegproblemen rekening gehouden moet worden met het seizoen waarin de waarnemingen hebben plaatsgevonden. Dat zou, bijvoorbeeld, kunnen door gebruik te maken van het gemiddelde van meerdere waarnemingen over meerdere seizoenen, of door bedrijven met elkaar te vergelijken waar de waarnemingen zijn uitgevoerd in hetzelfde seizoen.

\subsection{Bruikbaarheid Welfare Quality ${ }^{\circledR}$ protocol in de praktijk}

Dit onderzoek heeft laten zien dat het Welfare Quality ${ }^{\circledR}$ protocol voor vleeskalveren in principe goed uitvoerbaar is in de praktijk, en dat de waarnemingen grotendeels betrouwaar en nauwkeurig kunnen worden uitgevoerd door getrainde en gemotiveerde van erfbetreders, zoals SKV buitendienst medewerkers, die voorafgaand aan het onderzoek geen specifieke voorkennis over het protocol hadden. Aan de succesvolle realisatie van de waarnemingen waren wel een aantal cruciale voorwaarden verbonden:

- De waarnemingen waren arbeidsintensief en konden met de gevraagde frequentie alleen worden gedaan omdat SKV waarnemers bijna full-time beschikbaar waren.

- Voor de coördinatie en timing van waarnemingen, waarbij bezoeken aan vleeskalverbedrijven en slachthuizen op het juiset moment moesten plaatsvinden, kon in dit project een beroep gedaan worden op de expertise en faciliteiten van SKV.

- De beoogde SKV waarnemers waren in staat om voorafgaand aan het eigenlijke onderzoek een training te volgen, en hun expertise ten aanzien van de waarnemingsprotocollen gedurende langere tijd te onderhouden en aan de hand van een "opfriscursus" met herexamen tussentijds te toetsen. 
Hoewel de in dit project toegepaste training in combinatie met een tussentijdse afstemming met herexamen tot een grotendeels aanvaardbaar niveau van nauwkeurigheid van waarnemen door de SKV waarnemers heeft geleid, kwam ook aan het licht dat de variatie in nauwkeurigheid tussen waarnemers soms aanzienlijk was, en dat waarnemers in de loop van het project minder nauwkeurig werden en afwijkingen ten opzichte van de referentie lieten zien ("drift"). Zeker wanneer hoge eisen worden gesteld aan data die middels monitoring worden verkregen, bijvoorbeeld wanneer de uitkomsten de basis moeten vormen voor een betrouwbare (individuele) benchmark, is verdere aandacht voor de training en het onderhouden van de vaardigheden van de waarnemers gewenst.

- De validiteit en betrouwbaarheid van een welzijnsprotocol worden voor een belangrijk deel bepaald door de kwaliteit van de training van de waarnemers. Daarmee is in dit project een goed begin gemaakt, maar er is ruimte voor verbetering, ondermeer om het ontstaan van afwijkingen tussen de waarnemers en de referentie ("drift") te minimaliseren.

De betrokkenheid van kalverhouders en adviseurs bij het project was minder groot dan gewenst. Uiteindelijk werd ongeveer $25 \%$ van de kalverhouders en adviseurs persoonlijk bereikt via informatieen demonstratiebijeenkomsten. De kalverhouders en adviseurs die aan de bijeenkomsten hebben deelgenomen waren daar over het algemeen positief over gestemd.

De beoogde advisering aan kalverhouders op basis van de uitkomsten van de welzijnsmonitor liet ook enigzins te wensen over. In de loop van het project leidde maar een klein deel van de monitoringsuitslagen tot de formulering van een advies. Uiteindelijk zijn in totaal 97 adviezen uitgebracht; dat is $38 \%$ van de 256 adviezen die maximaal mogelijk waren geweest. Deze 97 adviezen hebben wel inzicht gegeven in de aard van de adviezen die adviseurs in de praktijk aan vleeskalverhouders geven als het gaat om bekende problemen zoals bijvoorbeeld aandoeningen van kalveren aan de luchtwegen of het maagdarmkanaal. De aard en reikwijdte van de verstrekte adviezen waren zeer divers, en op hetzelfde probleem werden vaak zeer verschillende deeladviezen gegeven.

- Adviseurs verschillen aanzienlijk in hun adviezen aan kalverhouders naar aanleiding van de uitkomsten van de welzijnsmonitor vleeskalveren. Dit suggereert dat er in de praktijk geen duidelijke consensus (of "common good practice") bestaat over de aanpak en oplossing van algemeen voorkomende gezondheids- en welzijnsproblemen van vleeskalveren. De in dit project gedocumenteerde adviezen en maatregelen representeren feitelijk alle mogelijke opties die een kalverhouder en zijn/haar adviseur op basis van gezond verstand ten dienste staan, en lijken vaak op een proces van "trial en error".

\subsection{Aanbevelingen}

- Aanbevolen wordt om (elementen van) het welzijnsprotocol routinematig toe te laten passen door nader te selecteren adviseurs werkzaam in de sector (zoals kalverspecialisten, rayonhoofden e.d.), kwaliteitsmedewerkers op slachthuizen, of medewerkers van controlerende instanties zoals SKV, tijdens bezoeken aan vleeskalverbedrijven en slachthuizen. In eerste instantie zou gekozen kunnen worden voor dié parameters die gemakkelijk bij grote aantallen dieren op dezelfde plek te registreren zijn, zoals bijvoorbeeld afwijkingen aan organen aan de slachtlijn, en/of voor een relatief eenvoudige set aan klinische parameters die gemakkelijk bij het levende kalf zijn waar te nemen. Over de keuze van een relevante subset van parameters uit de welzijnsmonitor zou in eerste instantie kunnen worden nagedacht door vertegenwoordigers van de sector en van WUR.

- Streef daarbij naar het verkrijgen van objectieve, uniforme en vergelijkbare gegevens; alleen dan kan aan de verzamelde gegevens meerwaarde worden gegeven, bijvoorbeeld door het opzetten van een benchmark, het identificeren van risicofactoren voor gezondheid en welzijn van vleeskalveren, of het toetsen van de effecten van voedings- en management interventies.

- Leid daarvoor waarnemers op aan de hand van een grondige, wetenschappelijk verantwoorde en effectieve training, inclusief regelmatige afstemmingssessies en opfriscursussen.

Aanbevolen wordt om dit intensiever en grootschaliger te doen dan in het huidige project, 
zodanig dat voor alle kenmerken waarvoor waarnemers worden opgeleid kwantitatieve kwaliteitscriteria voor de mate van nauwkeurigheid van de waarnemers (zoals bijvoorbeeld de sensitiviteit en de specificiteit) herhaald kunnen worden bepaald, en het optreden van "drift" aan de hand van deze criteria tijdig kan worden opgespoord en gecorrigeerd.

- Aanbevolen wordt om onder kalverhouders, adviseurs uit de sector, dierenartsen en eventueel andere erfbetreders en stakeholders, begrip en commitment te kweken voor de welzijnsmonitor, of bepaalde elementen daaruit, door het organiseren van informatie- en demonstratiebijeenkomsten.

- Aanbevolen wordt om in dit verband ook te kijken naar effectieve(re) methoden voor het presenteren van monitoringsgegevens, en het definiëren en hanteren van grenswaarden (normatief kader). Er zou bijvoorbeeld gedacht kunnen worden aan een figuur zoals Figuur 4 van dit rapport, met het accent op benchmarking, waarin tevens met horizontale stippellijnen bepaalde grenswaarden zijn opgenomen.

- In dit project zijn grenswaarden gehanteerd die zijn afgeleid uit een eerdere data-set. Aanbevolen wordt om ook na te denken over andere manieren voor het vaststellen van grenswaarden, bijvoorbeeld op basis van regelmatig geactualiseerde data-sets, en/of in samenwerking met andere stakeholders (zoals bijvoorbeeld beleid, NGOs of retail).

- Aanbevolen wordt om (elementen van de) welzijnsmonitor niet alleen te gebruiken voor het benchmarken van individuele bedrijven, groepen van bedrijven of bedrijfssystemen, maar vooral ook voor het uitvoeren van risicofactoranalyses en interventiestudies.

- In het kader van risicofactoranalyses wordt aanbevolen om gedurende langere periodes systematisch en gelijktijdig op een groot aantal vleeskalverbedrijven zowel dierkenmerken (d.w.z. de gezondheids- en welzijnskenmerken uit de welzijnsmonitor vleeskalveren, of een selectie daaruit) als omgevingskenmerken (d.w.z. informatie over huisvesting, voeding, herkomst kalveren, ventilatiesysteem, klimaat etc.) te verzamelen, en met behulp van epidemiologische en statistische technieken de relaties daartussen te analyseren. Op deze manier wordt duidelijk door welke (combinatie van) houderijfactoren, en in welk mate, bepaalde dierkenmerken worden beïnvloed, en kunnen antwoorden worden gevonden op vragen als: "welke voerstrategie is geassocieerd met de minste plaque", of "welk ventilatiesysteem geeft de minste longproblemen" etc. Deze kennis kan de basis vormen voor het formuleren van concrete maatregelen en handelingen waarmee gezondheid en welzijn van vleeskalveren in de praktijk kunnen worden verbeterd. Dit is: het bieden van "handelingsperspectief".

- Omdat op een aantal belangrijke kenmerken, met name rond luchtwegproblemen, ook andere factoren dat de omstandigheden op het vleeskalverbedrijf van invloed lijken te zijn, wordt aanbevolen om dergelijke risicofactoranalyses vooral ook uit te breiden naar andere schakels in de keten, in het bijzonder het melkveebedrijf van herkomst.

- Daaraan gekoppeld kunnen interventiestudies onder praktijkomstandigheden worden uitgevoerd, waarbij doelbewust wordt gevarieerd in voerstrategie, ventilatiesysteem, of welke andere houderijomstandigheid dan ook - op het vleeskalverbedrijf maar ook in andere schakels van de keten zoals op het melkveebedrijf van oorsprong, en vervolgens systematisch wordt gevolgd hoe objectief waargenomen parameters uit de welzijnsmonitor veranderen.

- Aanbevolen wordt om (elementen uit) de welzijnsmonitor te integreren met andere reeds beschikbare of in ontwikkeling zijnde informatiebronnen en -systemen, zoals het KalfVolgsysteem, InfoKalf of Kalf OK, en om strategieën ter verbeteringen van gezondheid en welzijn ketenbreed tot stand te brengen. Dit kan tevens de basis vormen voor het ontwikkelen respectievelijk verbeteren van een goed onderbouwde "common good practice" voor de Nederlandse vleeskalverhouderij. 


\section{Literatuur}

Animal Sciences Group van Wageningen UR, University of Padova (Italy), Institut Supérieur d'Agriculture (ISA) Lille (France), 2010. Report on the development of an on-farm welfare monitoring in veal calves. Results project 2007-2009, 176 pp.

Biometris \& Wageningen Livestock Research, 2012. Gedetailleerde resulaten vereenvoudigingsonderzoek WQ protocol vleeskalveren. Niet gepubliceerde notitie, $16 \mathrm{pp}$.

Bokkers, E.A.M., Leruste, H., Heutinck, L.F.M., Wolthuis-Fillerup, M., van der Werf, J.T.N., Lensink, B.J., van Reenen, C.G., 2009. Inter-observer and test-retest reliability of on-farm behavioural observations in veal calves. Animal Welfare 18, 381-390.

Brscic, M., Botreau, R., Thissen, J., Veissier, I., 2011. Report on the construction of welfare criteria for different livestock species. Part 3 - criteria construction for veal calves on farm. Deliverable 2.8c, subtask 2.3.1.2. Welfare Quality Project, EU Food-CT-2004-506508, 87 pp.

Brscic, M., Leruste, H., Heutinck, L.F.M., Bokkers, E.A.M., Wolthuis-Fillerup, M., Stockhofe, N., Gottardo, F., Lensink, B.J., Cozzi, G., van Reenen, C.G., 2012. Prevalence of respiratory disorders in veal calves and potential risk factors. Journal of Dairy Science 95, 2753-2764.

Kenward, M. G. and J. H. Roger. 1997. Small sample inference for fixed effects from restricted maximum likelihood. Biometrics. 53:983-997.

Leruste, H., Brscic, M., Cozzi, G., Kemp, B., Wolthuis-Fillerup, M., Lensink, B.J., Bokkers, E.A.M., van Reenen, C.G., 2014. Prevalence and potential influencing factors of non-nutritive oral behaviors of veal calves on commercial farms. Journal of Dairy Science 97, 7021-7030.

Van Reenen, C.G., Wolthuis, M., Heeres, J., Wesselink, M., Cappon, M., Bokkers, E., 2015. Towards implementation of farm animal monitoring in practice: example from the veal industry. In: Mounier, L., Veissier, I. (Editors), Proceedings of the $6^{\text {th }}$ International Conference on the Assessment of Animal Welfare at Farm and Group Level, 3 - 5 September, Clermond-Ferrand, Frankrijk, p. 202. 


\section{Bijlage 1 Anamnese}

Vooraf:

\begin{tabular}{|l|l|}
\hline Hoeveel probleem kalveren (ziekte, & Aantal invullen
\end{tabular}

verwondingen, achterblijvers etc.) heeft $u$ op dit

moment? En waar staan ze?

\begin{tabular}{|l|l}
\hline Aantal kalveren uitgevallen & Aantal invullen
\end{tabular}

Achteraf:

\begin{tabular}{|l|l|}
\hline $\begin{array}{l}\text { Hoeveel garantie kalveren waren er bij } \\
\text { aankomst? }\end{array}$ & Aantal invullen \\
\hline $\begin{array}{l}\text { Hoeveel kalveren van de garantie kalveren zijn } \\
\text { er nu nog in de koppel? }\end{array}$ & Aantal invullen \\
\hline $\begin{array}{l}\text { Hoe was de kwaliteit van het gehele koppel bij } \\
\text { aankomst (uitgaande van gemiddeld)? }\end{array}$ & Goed / matig / slecht \\
\hline $\begin{array}{l}\text { Is er op dit moment sprake van een } \\
\text { medicamenteuze koppel behandeling? (indien } \\
\text { van belang toelichten bij werkblad } \\
\text { opmerkingen) }\end{array}$ & Ja/ Nee \\
\hline Hoeveel kalveren zijn er van de melk af ? & Aantal invullen \\
\hline $\begin{array}{l}\text { Zijn er urinedrinkers in het koppel? } \\
\text { Worden de urinedrinkers uit de groep gehaald } \\
\text { (geïsoleerd)? }\end{array}$ & Ja/ Nee \\
\hline $\begin{array}{l}\text { Hoe is de melkopname (naar mening van de } \\
\text { kalverenhouder) van het koppel op dit moment } \\
?\end{array}$ & Goed/ Matig/ Slecht \\
\hline $\begin{array}{l}\text { Hoe is de ruwvoeropname (naar mening van de } \\
\text { kalverenhouder) van het koppel op dit moment? }\end{array}$ & Goed/ Matig/ Slecht \\
\hline
\end{tabular}




\section{Bijlage 2 Protocol Calf Escape Test (CET)}

\begin{tabular}{ll}
\hline Titel & Angst voor mens (Calf Escape Tests) \\
\hline Type parameter & Dierparameter; maakt onderdeel uit van het gedragsprotocol \\
\hline Beschrijving methode & $\begin{array}{l}\text { De CET is een test om de reactie van het kalf te meten op een actieve benadering van een } \\
\text { onbekende persoon. De warnemer gaat het hok in. Vervolgens gaat de waarnemer op een } \\
\text { rustige, gestandaardiseerde manier naar een kalf in het hok, waarna hij/zij probeert met de hand } \\
\text { de snuit van het kalf te raken. Reacties van het kalf worden genoteerd evenals de afstand tot het } \\
\text { kalf op het moment dat een reactie optreedt. }\end{array}$
\end{tabular}

- Hokken zijn bekend en testvolgorde is bepaald.

- Kleine groepen: alle kalveren in het hok worden benaderd.

- Grote groepen: een random percentage kalveren uit het hok (kalveren worden vooraf geselecteerd).

- $\quad$ Licht is aan in stal.

- Kalveren worden in staande positie benaderd. Indien kalveren blijven liggen worden deze geactiveerd door de waarnemer door het hok in te gaan en rustig rond te gaan lopen.

- De benadering van elk kalf is kop-gericht, d.w.z. dat met enigszins gestrekte arm éénmaal per kalf geprobeerd wordt om de snuit van het kalf aan te raken.

Test:

De waarnemer gaat het hok binnen wacht even om de kalveren te laten wennen.

De waarnemer kiest een kalf (in kleine groepen een willekeurig kalf; in grote groepen een kalf van de lijst) dat frontaal op twee armlengtes van de waarnemer staat.

De waarnemer probeert oogcontact met het kalf te maken.

De waarnemer doet langzaam (ongeveer 1 seconde per stap) 1 stap voorwaarts richting het kalf (met uitgestrekte arm) en sluit met het andere been aan.

De waarnemer blijft even staan.

Als het kalf blijft staan doet de waarnemer een tweede stap voorwaarts en sluit met het andere been aan.

Als het kalf blijft staan probeert de waarnemer het kalf aan te raken.

Als het kalf nog niet meteen wordt aangeraakt, kunnen zowel kalf als waarnemer het initiatief nemen dit alsnog te doen, daarvoor is $5 \mathrm{~s}$ de tijd.

De test is afgelopen op het moment dat het kalf zich terugtrekt, of wegdraait. Elk kalf heeft maximaal 3 kansen om oogcontact te maken. Als de waarnemer tijdens deze 3 pogingen geen oogcontact krijgt wordt dit genoteerd. In grote groepen geldt dit ook voor kalveren die niet benaderbaar zijn (kalf bevindt zich altijd aan de andere kant van het hok of verstopt zich achter andere kalveren).

Individueel niveau:

Score 0: Geen oogcontact

Score 1: Oogcontact gelukt, stap 1 niet

Score 2: Oogcontact en stap 1 gelukt, stap 2 niet

Score 3: Oogcontact, stap 1 en stap 2 gelukt, aanraken niet

Score 4: Kalf aangeraakt

Percentage kalveren dat aangeraakt kan worden
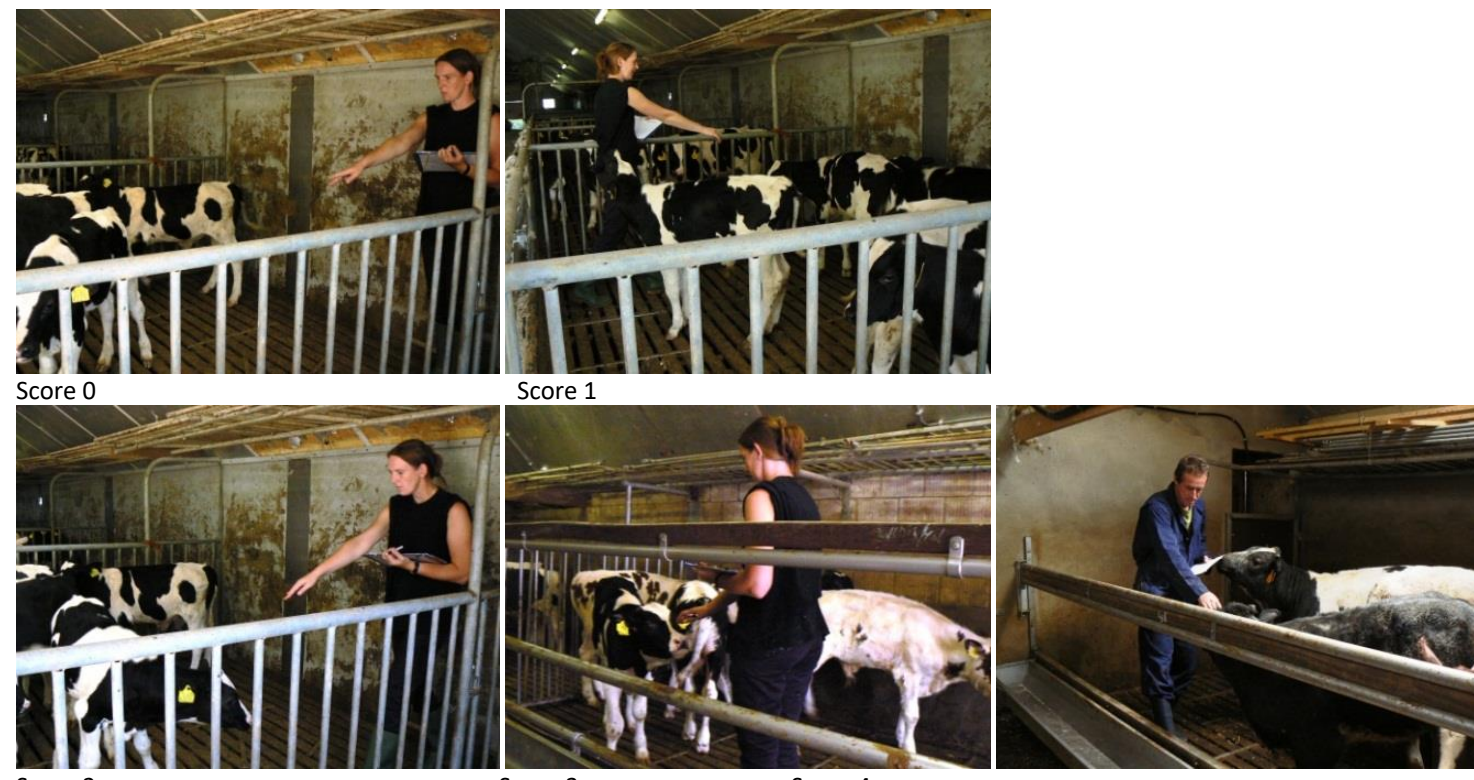


\section{Bijlage 3 Protocol drinkwatervoorziening, gladheid vloer en reinheid kalf}

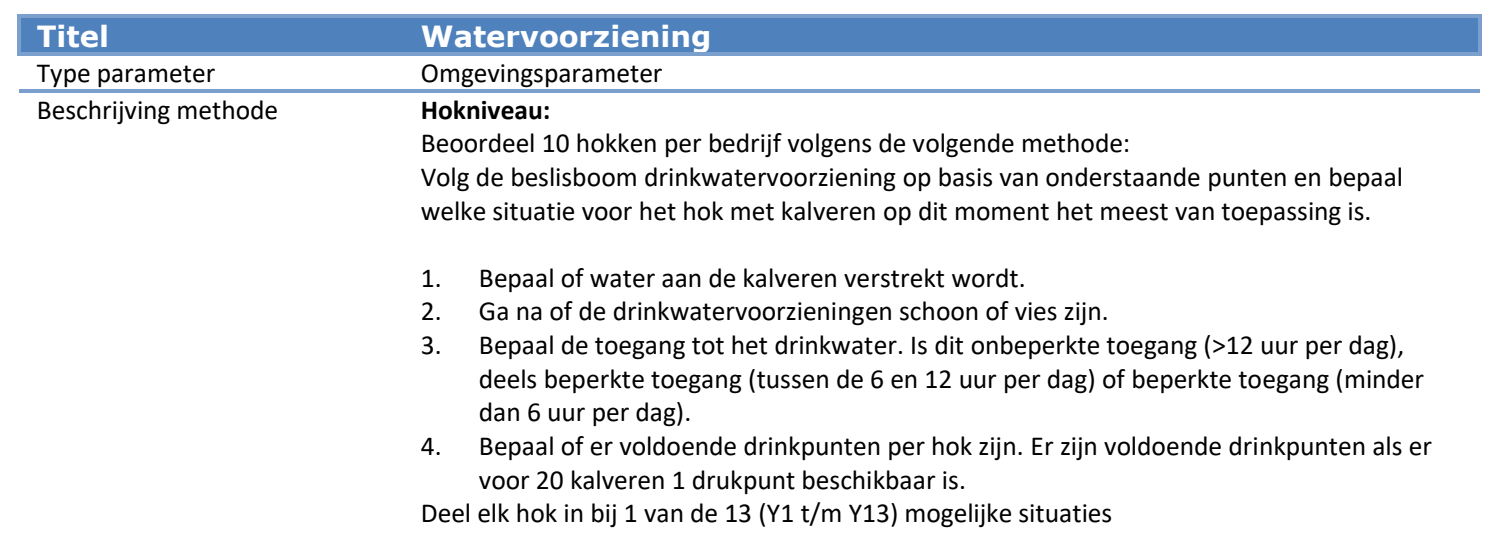

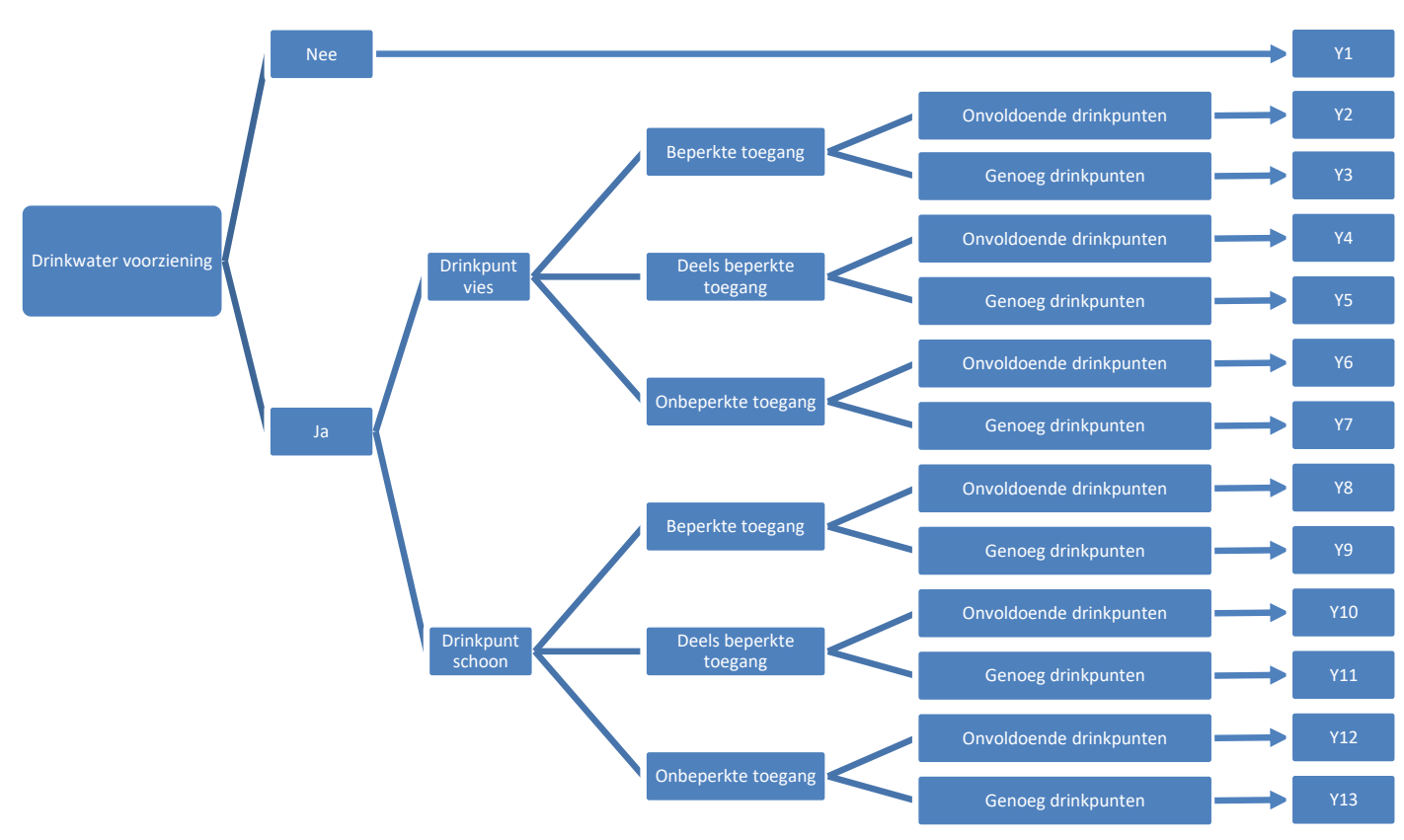

gesignaleerd is ( $\mathrm{Y} 1$ is slecht en $\mathrm{Y} 13$ is goed). 


\section{Hokniveau:}

Beoordeel 10 willekeurig gekozen hokken per bedrijf, waarbij elk hok een kwalitatieve gladheid score krijgt:

Gevaarlijk:

Vloeren met gaten in de vloer die zo groot zijn, dat een kalf er met zijn poot door kan zakken (door bijvoorbeeld een missende lat).

Erg glad: $>75 \%$ van het oppervlakte is glad en nat. Het is moeilijk om op de vloer te staan, kalveren bewegen moeilijk en niet veilig. Dit wordt bijvoorbeeld gezien op oude afgeronde hardhouten roosters die nat zijn geworden door urine en mest met of zonder aluminium strips tegen het uitglijden.

Glad: $50-75 \%$ van het oppervlakte is glad en nat.

Bijvoorbeeld rechte hardhouten roosters die nat zijn geworden door urine en mest met of zonder aluminium strips tegen het uitglijden.

Glibberig: $30-50 \%$ van het oppervlakte is glad en nat.

Vaak te zien bij hardhouten roosters met aluminium strips tegen het uitglijden. Of bij bepaalde latten op de vloer zijn bedekt met rubber. Of bij natte betonnen (rooster) vloeren

Enigszins glad: $<30 \%$ van het oppervlakte is glad en nat. Gladheid is grotendeels beperkt, waargenomen op bijvoorbeeld bepaalde hardhouten roostervloeren, met rubber en op droge betonnen roosters. Niet glad: Kalveren glijden nooit uit. Dit is bijvoorbeeld te zien bij

kalveren op een dikke laag stro (bv. $40 \mathrm{~cm}$ ), vloeren bedekt met zand of buiten op het weiland. 


\section{Dierparameter}

Beschrijving methode

Beoordeel in 10 hokken per bedrijf elk kalf volgens de volgende methode:

Kies een kant van het kalf wat duidelijk zichtbaar is en beoordeel van elk kalf de volgende onderdelen:

1: Voorpoot

2: Buik

3: Achterpoot

4: Achterhand

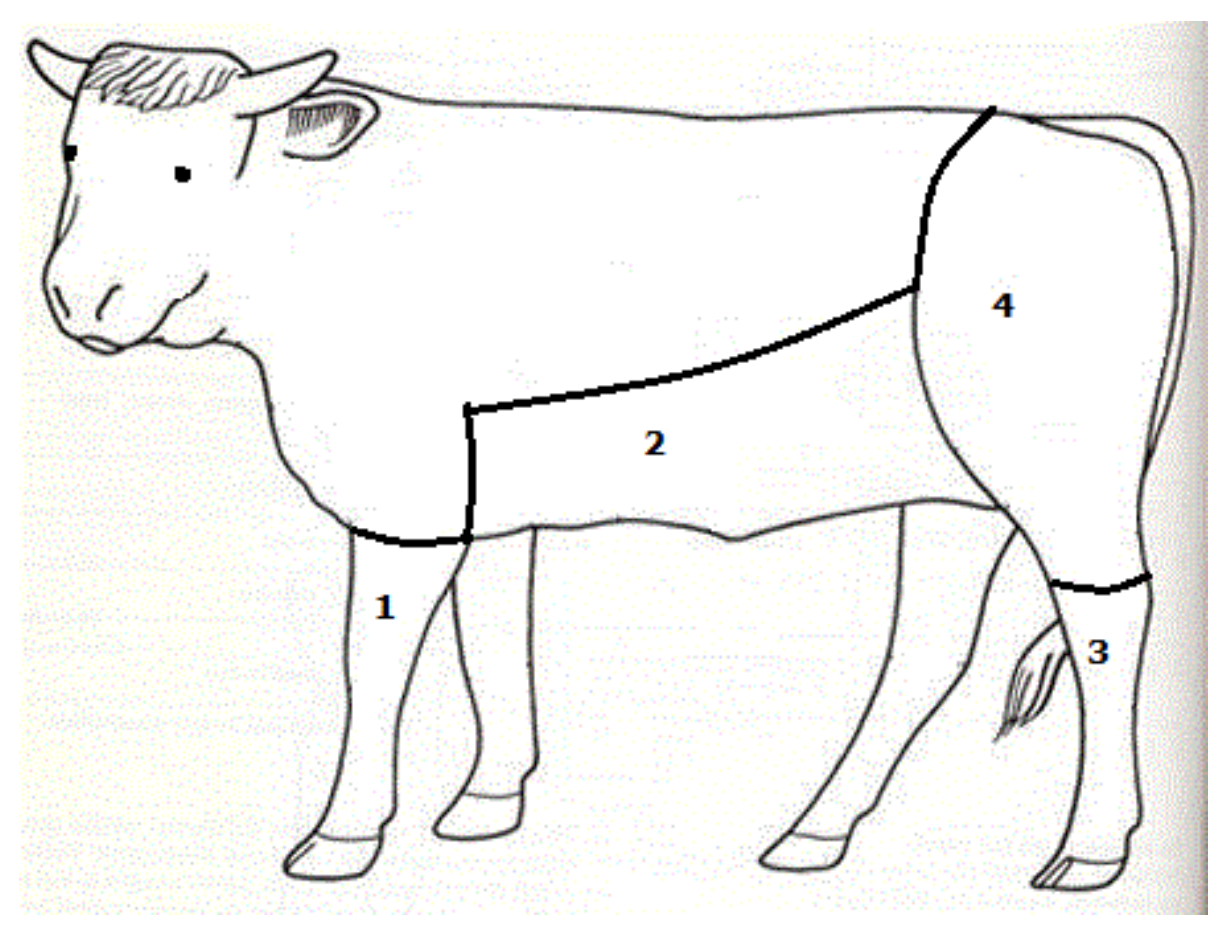

Elk onderdeel wordt beoordeeld volgens de onderstaande score:

$0: \quad<50 \%$ van het te beoordelen gebied is bevuild.

1: $\quad>50 \%$ van het te beoordelen gebied is bevuild.

Tel het totaal aantal punten per onderdeel op en noteer de score per kalf. De maximale score per kalf is 4 . 


\section{Bijlage 4 Protocollen pathologie}

\section{Longen}

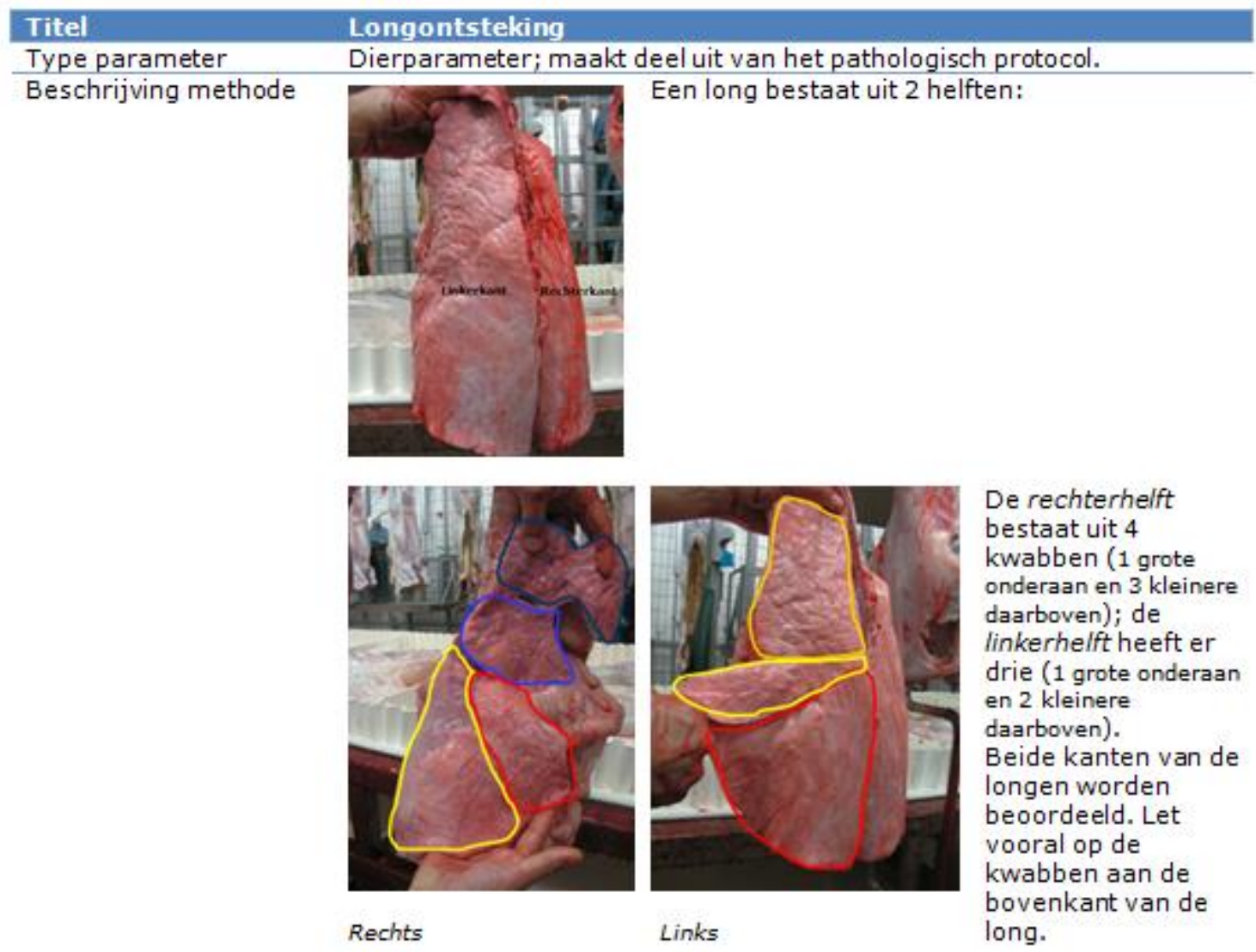




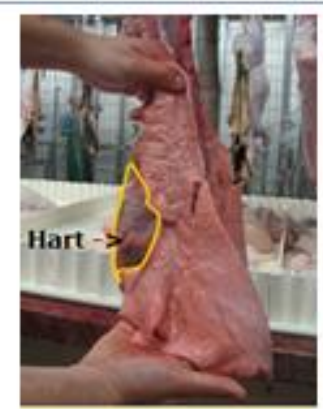

Let op: soms is hart zichtbaar terwijl de long onderzocht wordt. Deze is donkerder dan de long zelf, verwar deze niet.

Hoe herken je een long met longontsteking?

Een normale long (groen omcirkeld) heeft een bleke oranje kleur. Een

long met longontsteking (rood omcirkeld) heeft rood-grijze

kleurafwijkingen:

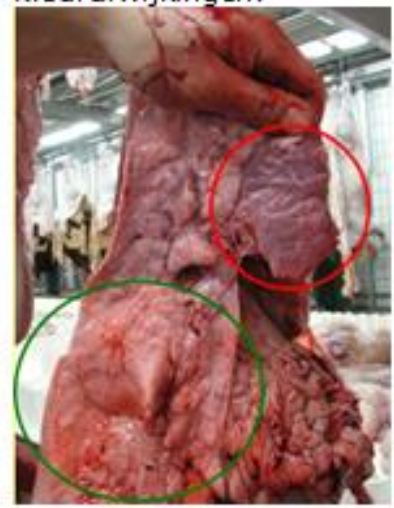

Beoordeel in het slachthuis per bedrijf 200 longen volgens de beschreven methodiek op longontsteking.

\section{Individueel niveau:}

0: Geen veranderingen

1: Minimaal; 1 kleine ontstekingshaard in een kwab

2: $\quad$ Mild tot matig; 1 grote of meerdere kleine

ontstekingshaard(en) per longhelft.

3: $\quad$ Ernstig; per longhelft een of meerdere kwabben grotendeels of volledig aangetast.

\section{Bedrijfsniveau:}

Percentage longen met minimaal, mild en ernstige longontsteking

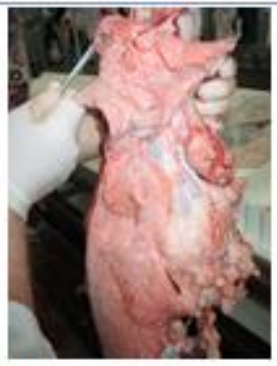

Score 0

Geen verkleuringen

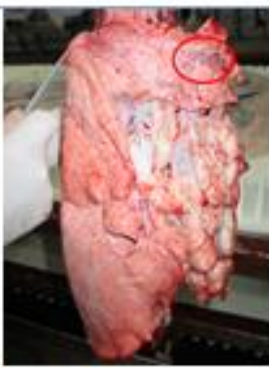

Score 1 1 kleine beschadiging

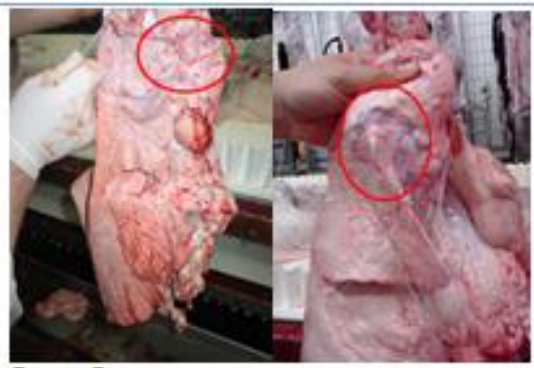

Score 2

Meerdere ontstekingshaarden (foto 1 en 2) 
Abscess=round cavity filled with pus
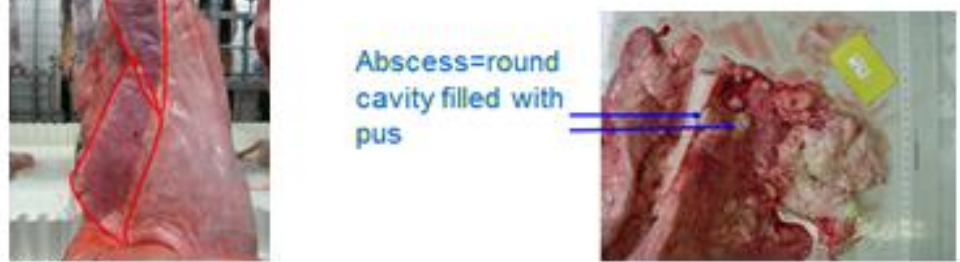

Score 3

Een ernstige beschadigde long treft 1 of meerdere longkwabben (in dit geval 2) en laat soms ( $2^{\text {de }}$ foto) abcessen zien

(3) Wageningen UR Livestock Research

\begin{tabular}{ll} 
Titel & Pleuritis \\
Type parameter & Dierparameter; maakt deel uit van het pathologisch protocol \\
\hline Beschrijving methode & $\begin{array}{l}\text { Pleuritis is een borstvliesontsteking. Bij een normale long kunnen de } \\
\text { kwabben van elkaar worden gescheiden. Bij een long met pleuritis } \\
\text { kleeft het oppervlakte van de kwab aan andere kwabben of organen. }\end{array}$
\end{tabular}

Beoordeel in het slachthuis per bedrijf 200 longen volgens de beschreven methodiek op pleuritis.

Individueel niveau:

0 - Long zonder pleuritis

1 - Long met pleuritis

\section{Classificatie Bedrijfsniveau:}

Percentage longen met pleuritis

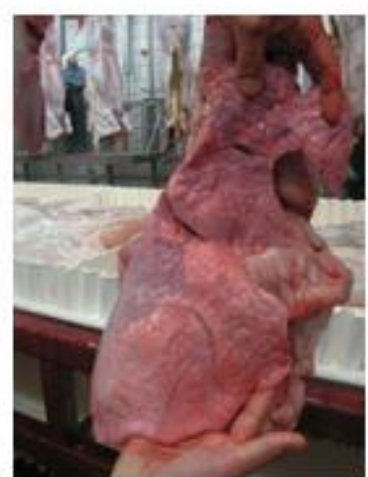

Score 0: Geen pleuritis

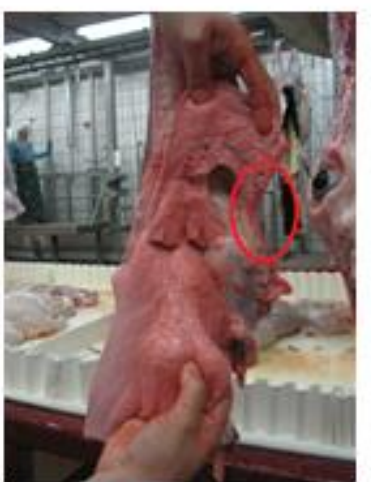

Score 1: Pleuritis

In dit geval is het oppervlakte van een kwab

vastgekleefd aan het weefsel rondom het hart 


\section{Lebmaag}

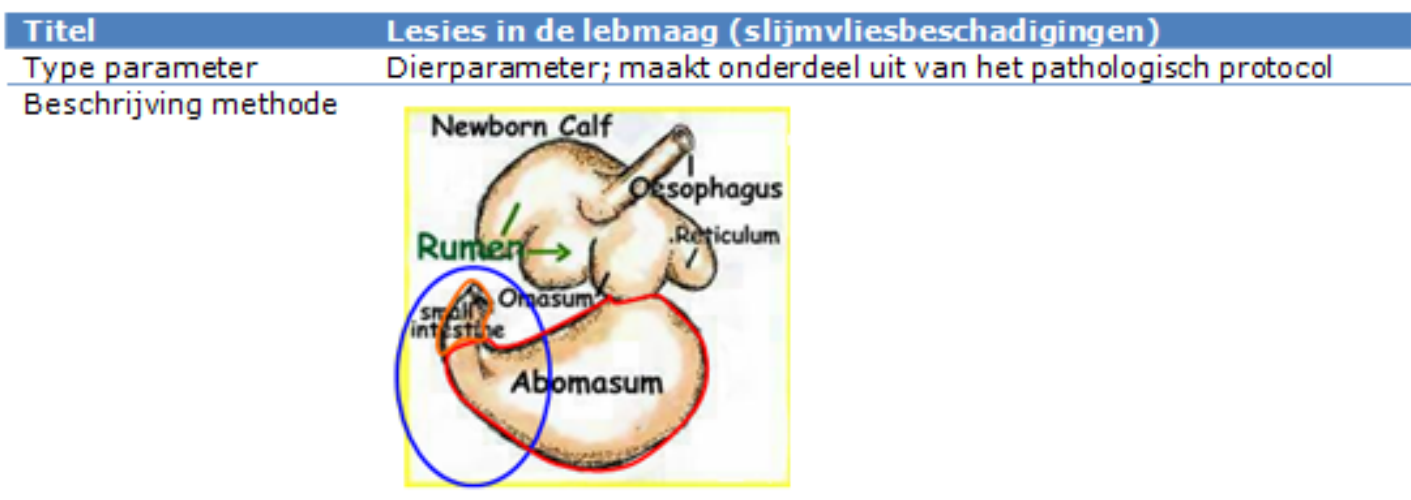

De lebmaag is gekoppeld aan de dunne darm (twaalfvingerige darm). De waarneming wordt uitgevoerd in het gebied waar het is aangesloten op de twaalfvingerige darm bij de maaguitgang (pyloric).

Daarvan wordt een stuk van $15 \mathrm{~cm}$ geknipt, waarna dit deel van de lebmaag in de lengterichting doorgeknipt wordt om zo een vlak beeld te verkrijgen.

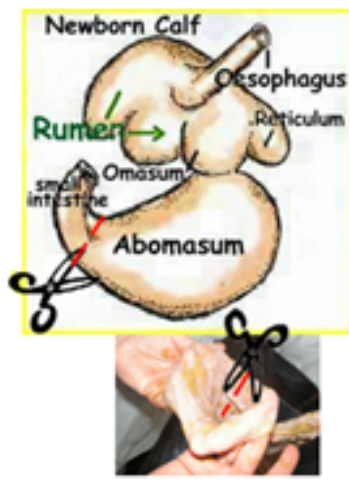

Het beeld wat je dan krijgt is:

In groen: wat vet

In het rood: de lebmaag

In oranje: de twaalfvingerige

darm

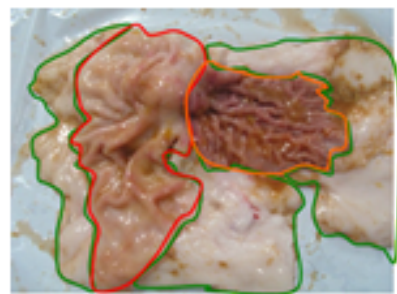

Waarnemingen worden in het rode deel gedaan. Gekeken wordt naar lesies in slijmvliezen. Daarbijwordt rekening gehouden met 3 parameters:

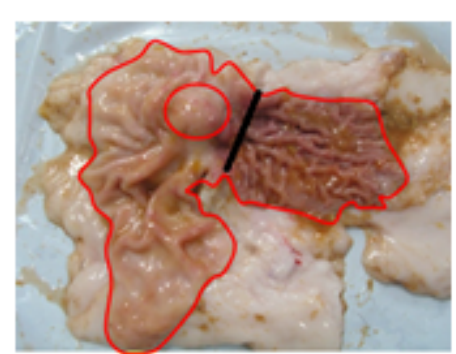

1 Ligaing:

Torus pylorus: Knopvormige structuur aan de verbinding van lebmaag en de twaalfvingerige darm (rode cirkel op foto).

Rest van de pyloric gebied: Gebied om torys pylorus heen 


\section{Grootte van de slijmvliesbeschadiaingen}

We onderscheiden 2 typen

slijmvliesbeschadigingen. Een maagzweer is een beschadiging wat te herkennen is als een open wond (gat) in het weefsel. Het ziet eruit als een zwart litteken of rode wond en het gaat tot binnen in het weefsel.

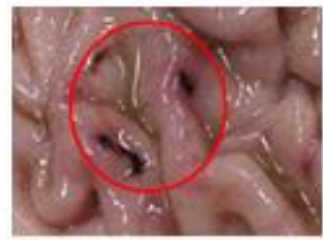

Een erosie is een oppervlakkige wond in het weefsel. Je ziet dat het niet binnen in het weefsel gaat.
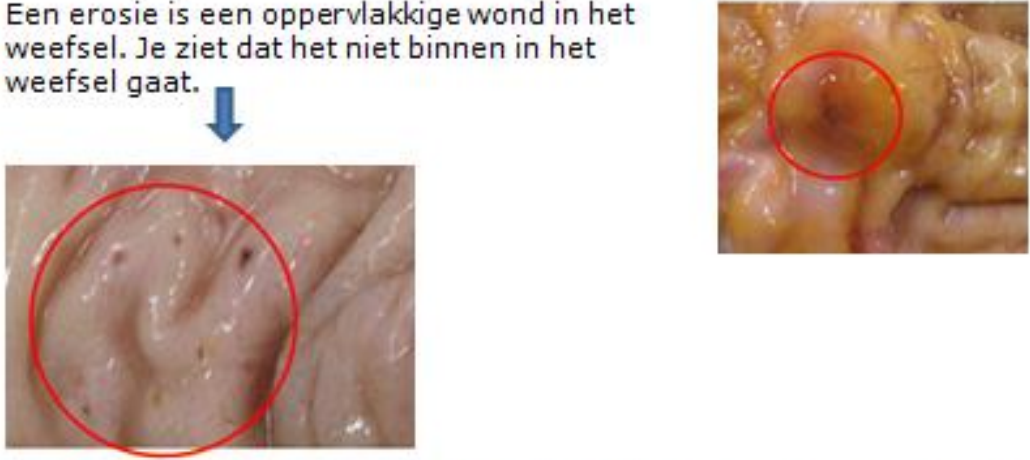

Voor de beoordeling moeten alle beschadigingen gescoord worden, dus zowel de maagzweren als de erosies. Deze kunnen in drie klassen ingedeeld worden:

I: Beschadigingen van $<0,5 \mathrm{~cm}^{2}$

II: Beschadigingen tussen $0,5 \mathrm{~cm}^{2}-1 \mathrm{~cm}^{2}$

III: Beschadigingen van $>1 \mathrm{~cm}^{2}$

\section{Aantal lesies}

Deze kwantificering wordt uitgevoerd per grootteklasse. Voor elke grootteklasse worden het aantal lesies genoteerd. Echter, de maximale score per klasse is 4 .

Opmerking: In het gebied van de Torus pylorus wordt alleen de aan- of afwezigheid van lesies genoteerd. Let niet op de kleur van de lebmaag, deze kan variëren van licht roze tot donker oranje:
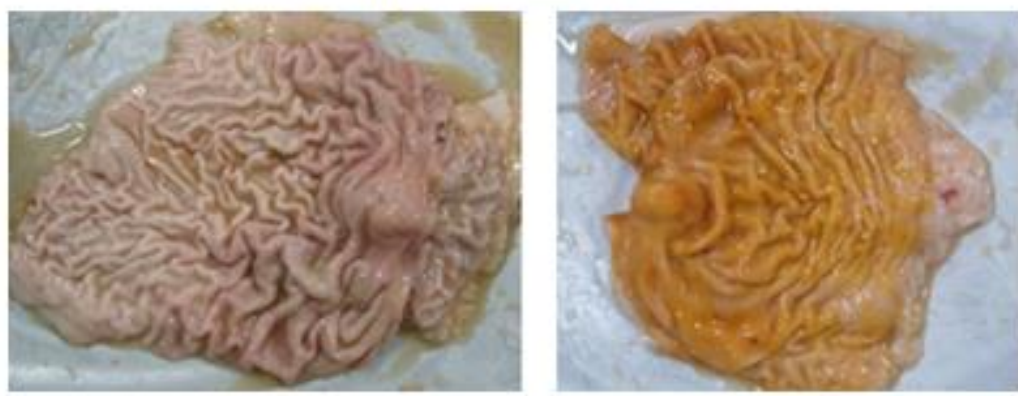

Individueel niveau:

Verzamel in het slachthuis perbedrijf 60 lebmagen.

Prepareer de lebmagen op de hierboven beschreven manier.

Beoordeel de lebmagen volgens bovenstaande methode en noteer de scoren op de volgende manier: 


\begin{tabular}{|l|l|l|l|l|l|}
\hline \multicolumn{4}{|l|}{ Pyloric gebied } & Torus pylorus \\
\hline Lebmaag & $\begin{array}{l}\text { Lesie } \\
(\mathrm{Ja=1} / \mathrm{Nee=}=0)\end{array}$ & Grootte 1 & Grootte 2 & Grootte 3 & $\begin{array}{l}\text { Lesie } \\
(\mathrm{Ja}=1 / \mathrm{Nee}=0)\end{array}$ \\
\hline 1 & & & & & \\
\hline 2 & & & & & \\
\hline
\end{tabular}

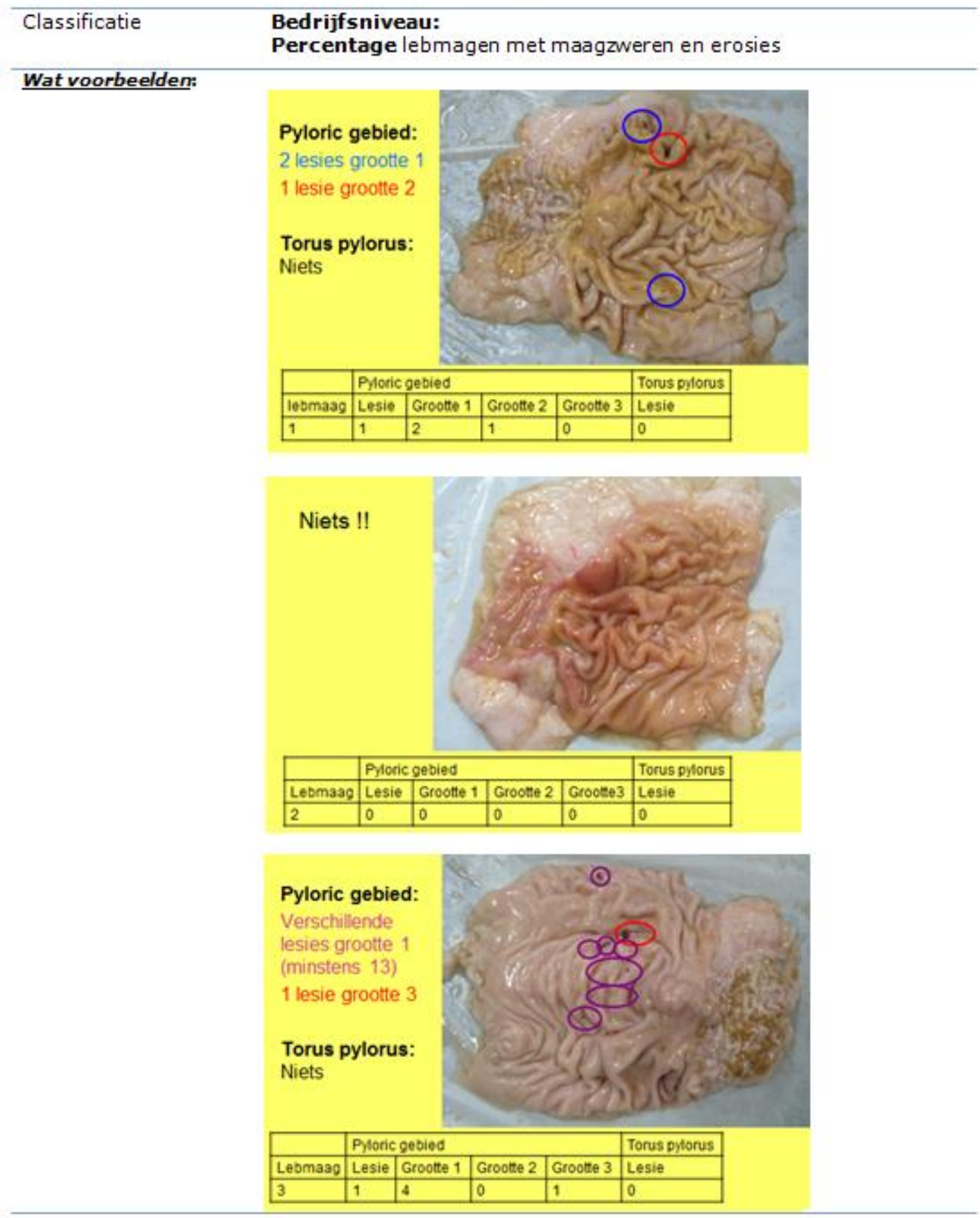




\section{Pens}

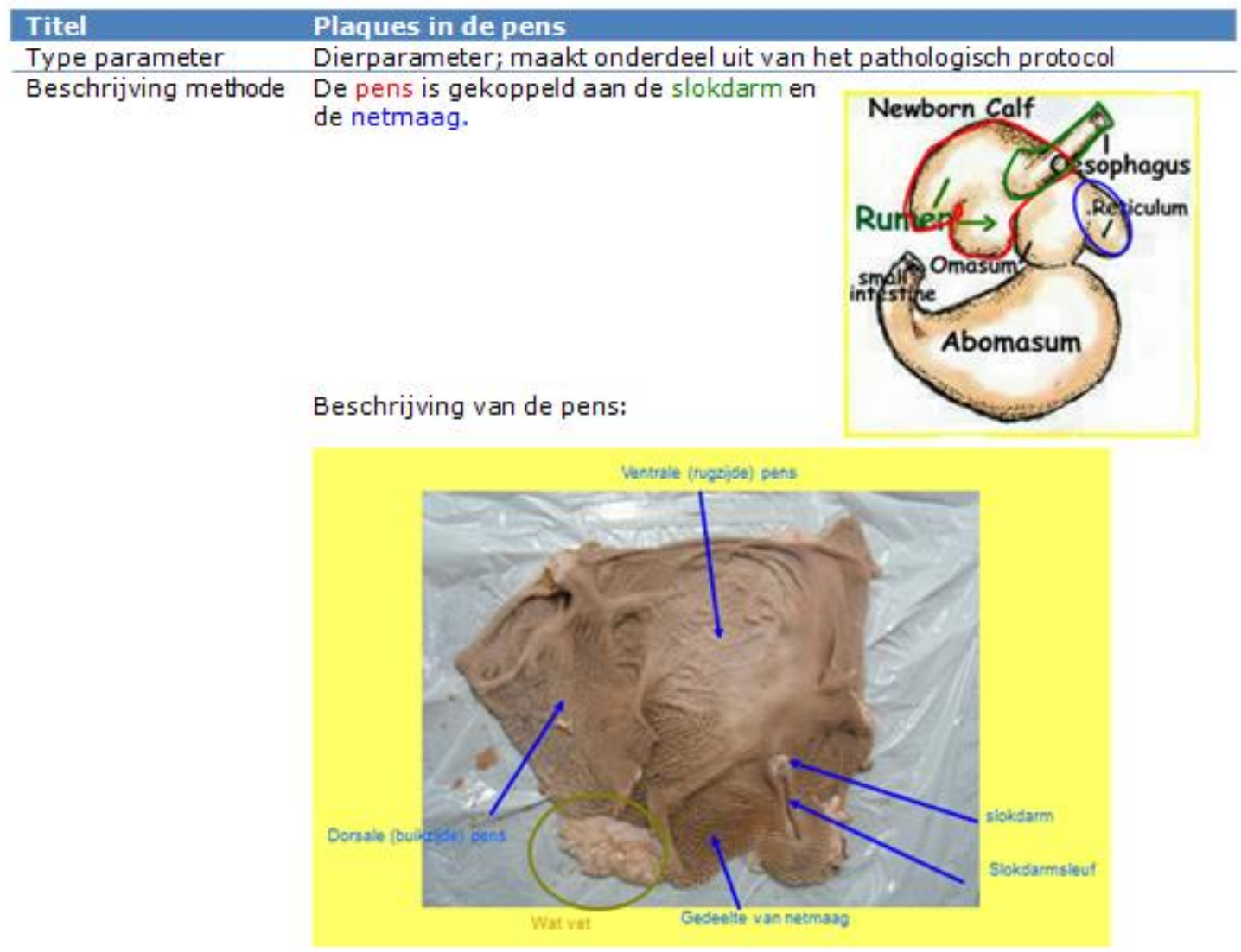

Beoordeel de pens op 3 vlakken:

Pens ontwikkeling:

Bij pens ontwikkeling kijkt men vooral naar de hoeveelheid pensvlokken. Pensvlokken zijn kleine vingerachtige uitstulpingen die het oppervlakte van de pens verhogen:
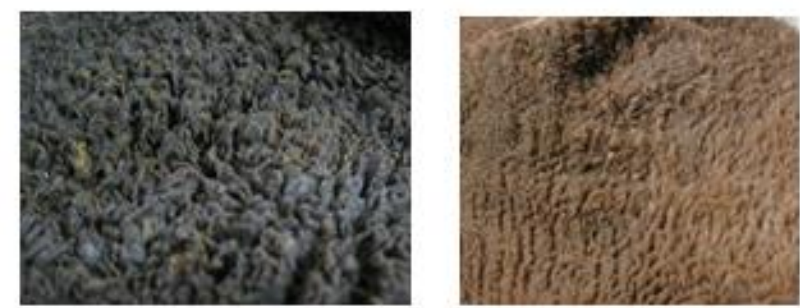

Voor de beoordeling van de pens ontwikkeling onderscheiden we 4 scores: erg lage, lage, lichte en hoge ontwikkeling:

Score 1: Bijna geen of alleen maar korte vlokken aanwezig in de

Score 2: $\quad$ Vlokken duidelijk aanwezig in het atrium, weinig vlokken in de dorsale en ventrale pens de onderliggende penswand is de dorsale en ventrale pens de onderliggende penswand
duidelijk te zien;

Score 3: Veel vlokken in het atrium, matig aantal vlokken in de zichtbaar; 

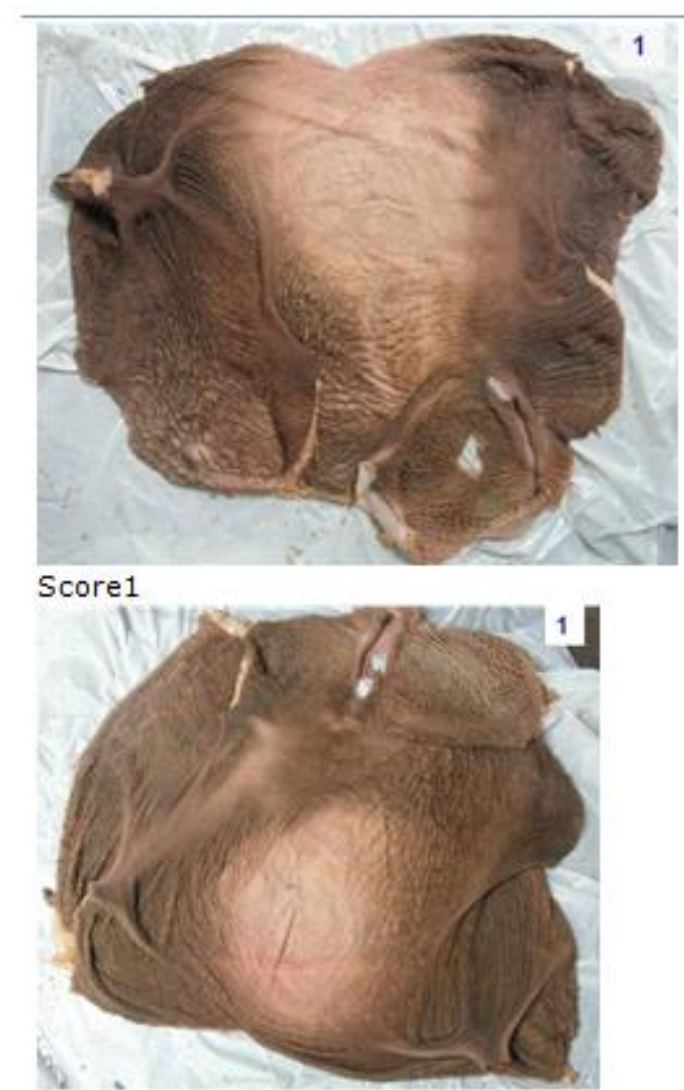

Score 3

(8) Wageningen UR Livestock Research

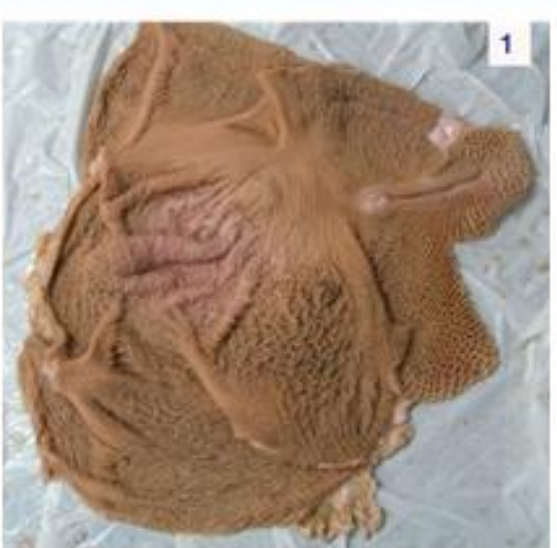

Score 2

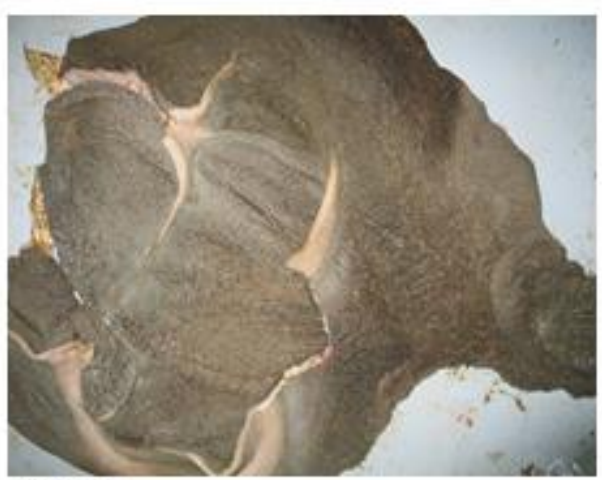

Score 4

\section{Titel Volle kalveren \\ Type parameter Dierparameter; maakt onderdeel uit van het klinisch protocol \\ Beschrijving methode Het gaat om kalveren die duidelijk gespannen staan in de buikstreek (boven/onder/links/rechts/rondom) met overduidelijke uitstulpingen ten opzichte van ribbenboog.}

Volstaan kan veroorzaakt worden door gas, vloeistof of beiden Alle type oplopers en volle kalveren moeten hier gescoord worden.

Individueel niveau:

0: $\quad$ Normale toestand

1: Vol kalf

Classificatie Bedrijfsniveau:

Percentage volle kalveren
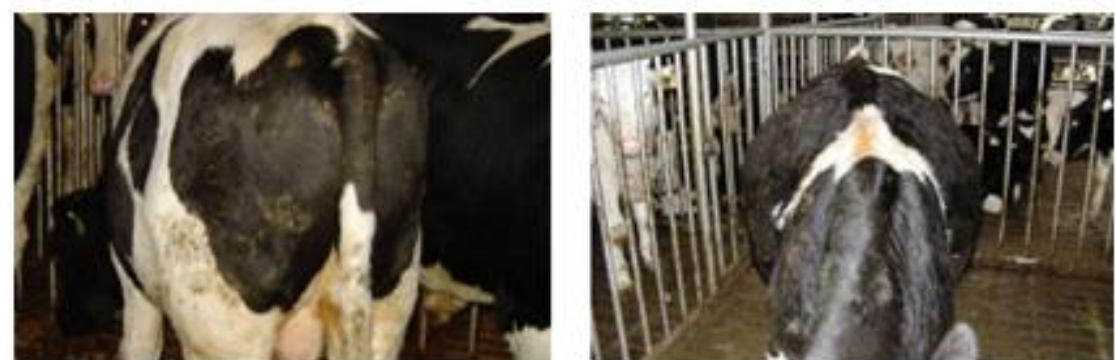

(3) ISA 


\section{Bijlage 5 Formulier voor adviseurs}

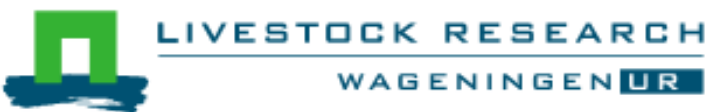

Bijlage 2: Formulier adviesgesprek

\begin{tabular}{|c|c|}
\hline UBN & \\
\hline Bedrijf & \\
\hline ronde & \\
\hline Adviseur & \\
\hline Datum & \\
\hline
\end{tabular}

Conclusie resultaten

Plan van Aanpak

1

2

3

4

5

6 


\section{Bijlage 6 Gemiddelde scores per ronde op 44 blankvleesbedrijven}

Gemiddelde scores per ronde voor de parameters van de welzijnsmonitor op 44 blankvleesbedrijven tijdens vier opeenvolgende rondes

\begin{tabular}{|c|c|c|c|c|c|c|c|c|}
\hline \multirow[t]{2}{*}{ Parameter } & \multicolumn{2}{|c|}{ Ronde 1} & \multicolumn{2}{|c|}{ Ronde 2} & \multicolumn{2}{|c|}{ Ronde 3} & \multicolumn{2}{|c|}{ Ronde 4} \\
\hline & $\overline{\text { Gem }^{1}}$ & SEM $^{2}$ & Gem & SEM & Gem & SEM & Gem & SEM \\
\hline \% kalveren aangeraakt tijdens calf escape test (CET) & $10.4^{\mathrm{a}}$ & 0.87 & $9.7^{\mathrm{a}, \mathrm{b}}$ & 1.09 & $7.8^{\mathrm{b}, \mathrm{c}}$ & 1.04 & $7.7^{c}$ & 1.13 \\
\hline$\%$ abnormaal oraal gedrag & $11.6^{\mathrm{a}}$ & 0.99 & $6.9^{\mathrm{b}}$ & 0.53 & $4.8^{c}$ & 0.50 & $4.4^{c}$ & 0.5 \\
\hline$\%$ afwijkende ademhaling & $3.6^{\mathrm{a}}$ & 0.49 & $5.9^{b}$ & 0.70 & $2.5^{\mathrm{a}}$ & 0.24 & $1.9^{\mathrm{a}}$ & 0.15 \\
\hline$\%$ neusuitvloeiing & $2.4^{\mathrm{a}}$ & 0.35 & $3.1^{\mathrm{a}}$ & 0.41 & $0.9^{\mathrm{b}}$ & 0.13 & $0.8^{\mathrm{b}}$ & 0.10 \\
\hline$\%$ hoesten & $3.8^{\mathrm{a}}$ & 0.34 & $3.9^{a}$ & 0.32 & $2.7^{\mathrm{b}}$ & 0.22 & $2.0^{c}$ & 0.20 \\
\hline$\%$ volle kalveren & $2.5^{\mathrm{a}}$ & 0.45 & $1.2^{\mathrm{a}}$ & 0.19 & $0.7^{\mathrm{b}}$ & 0.09 & $0.4^{\mathrm{b}}$ & 0.08 \\
\hline$\%$ kreupele kalveren & 1.0 & 0.16 & 0.7 & 0.13 & 0.5 & 0.08 & 0.3 & 0.06 \\
\hline \% dikke knieën (verkregen slijmbeurs) & $4.2^{\mathrm{a}}$ & 0.77 & $2.1^{\mathrm{b}}$ & 0.28 & $1.3^{\mathrm{c}}$ & 0.25 & $1.0^{c}$ & 0.14 \\
\hline$\%$ aangebeten staart & 0.1 & 0.08 & 0.1 & 0.06 & 0.0 & 0.01 & 0.0 & 0.00 \\
\hline$\%$ urine drinkers & 1.0 & 0.30 & 1.3 & 0.42 & 0.7 & 0.20 & 1.0 & 0.20 \\
\hline$\%$ achterblijvers ( $15-30 \%$ achterstand in conditie) & $3.9^{\mathrm{a}}$ & 0.38 & $3.6^{\mathrm{a}, \mathrm{b}}$ & 0.45 & $2.6^{\mathrm{b}}$ & 0.28 & $1.5^{\mathrm{c}}$ & 0.16 \\
\hline$\%$ muiters ( $>30 \%$ achterstand in conditie) & $1.9^{\mathrm{a}}$ & 0.30 & $2.3^{\mathrm{a}}$ & 0.40 & $1.0^{\mathrm{b}}$ & 0.16 & $0.5^{c}$ & 0.10 \\
\hline$\%$ natte kalveren & $1.3^{\mathrm{a}}$ & 0.31 & $5.2^{\mathrm{b}}$ & 0.87 & $6.1^{\mathrm{b}}$ & 0.96 & $5.4^{\mathrm{b}}$ & 1.43 \\
\hline$\%$ dorre kalveren & $4.0^{\mathrm{a}}$ & 0.50 & $4.1^{\mathrm{a}}$ & 0.49 & $1.9^{\mathrm{b}}$ & 0.21 & $1.4^{\mathrm{c}}$ & 0.17 \\
\hline
\end{tabular}




\begin{tabular}{|c|c|c|c|c|c|c|c|c|}
\hline \multirow{2}{*}{$\begin{array}{l}\text { Parameter } \\
\text { \% bevuilde kalveren }\end{array}$} & \multicolumn{2}{|c|}{ Ronde 1} & \multicolumn{2}{|c|}{ Ronde 2} & \multicolumn{2}{|c|}{ Ronde 3} & \multicolumn{2}{|c|}{ Ronde 4} \\
\hline & $\overline{6.1}$ & 0.91 & 7.7 & 1.2 & 5.5 & 0.79 & 5.3 & 0.55 \\
\hline$\%$ hokken met dunne mest & $11.0^{\mathrm{a}}$ & 2.05 & $9.1^{\mathrm{a}}$ & 1.27 & $6.3^{\mathrm{b}}$ & 0.89 & $5.3^{\mathrm{b}}$ & 1.0 \\
\hline$\%$ ernstig aangetaste longen & $14.2^{\mathrm{a}}$ & 0.99 & $17.4^{\mathrm{b}}$ & 1.25 & $16.1^{\mathrm{b}}$ & 1.00 & $12.0^{c}$ & 0.96 \\
\hline$\%$ longen met pleuritis & $65.1^{\mathrm{a}}$ & 2.39 & $50.0^{\mathrm{b}}$ & 2.06 & $46.9^{b, c}$ & 1.33 & $42.1^{c}$ & 1.74 \\
\hline$\%$ penzen met plaques & $66.3^{a}$ & 3.41 & $68.6^{a}$ & 3.87 & $64.7^{\mathrm{a}, \mathrm{b}}$ & 3.93 & $81.4^{b}$ & 2.81 \\
\hline Gemiddelde score pensontwikkeling van de koppel & $1.9^{\mathrm{a}}$ & 0.06 & $2.1^{\mathrm{b}}$ & 0.05 & $2.2^{\mathrm{b}}$ & 0.05 & $2.3^{\mathrm{c}}$ & 0.05 \\
\hline$\%$ lebmagen met lesies ${ }^{3}$ & $70.3^{\mathrm{a}}$ & 2.14 & $82.9^{b}$ & 1.40 & $86.4^{\mathrm{b}, \mathrm{c}}$ & 1.40 & $87.1^{c}$ & 1.32 \\
\hline$\%$ uitval & 4.7 & 0.30 & 4.3 & 0.34 & 4.2 & 0.30 & 4.0 & 0.30 \\
\hline
\end{tabular}

${ }^{1}$ Gem: gemiddelde

2SEM: Standard error of the mean (SEM), of standaardfout

${ }^{3}$ Een lebmaag met lesies is een lebmaag met één of meer lesies, los van de grootte

$a, b, c$ Gemiddelden met verschillende letters verschillen significant van elkaar $(P<0.05$, tweezijdige toets, Fisher's LSD) 


\section{Bijlage 7 Gemiddelde scores per ronde op 21 rosé bedrijven}

\begin{tabular}{|c|c|c|c|c|c|c|c|c|}
\hline \multirow[t]{2}{*}{ Parameter } & \multicolumn{2}{|c|}{ Ronde 1} & \multicolumn{2}{|c|}{ Ronde 2} & \multicolumn{2}{|c|}{ Ronde 3} & \multicolumn{2}{|c|}{ Ronde 4} \\
\hline & $\mathrm{Gem}^{1}$ & SEM $^{2}$ & Gem & SEM & Gem & SEM & Gem & SEM \\
\hline \% kalveren aangeraakt tijdens calf escape test (CET) & $9.4^{\mathrm{a}}$ & 1.49 & $10.9^{a}$ & 1.22 & $7.4^{\mathrm{b}}$ & 1.13 & $5.5^{c}$ & 0.89 \\
\hline$\%$ abnormaal oraal gedrag & $3.1^{\mathrm{a}}$ & 0.38 & $1.7^{\mathrm{b}}$ & 0.27 & $2.1^{\mathrm{a}, \mathrm{b}}$ & 0.31 & $1.8^{\mathrm{b}}$ & 0.26 \\
\hline$\%$ afwijkende ademhaling & $4.4^{\mathrm{a}}$ & 0.65 & $5.8^{\mathrm{a}}$ & 0.73 & $3.2^{\mathrm{b}}$ & 0.57 & $2.4^{\mathrm{b}}$ & 0.46 \\
\hline$\%$ neusuitvloeiing & $4.5^{\mathrm{a}}$ & 0.82 & $4.0^{\mathrm{a}}$ & 0.61 & $1.6^{\mathrm{b}}$ & 0.27 & $1.4^{\mathrm{b}}$ & 0.30 \\
\hline$\%$ hoesten & 5.8 & 0.73 & 5.7 & 0.52 & 5.2 & 0.54 & 4.0 & 0.70 \\
\hline$\%$ volle kalveren & $2.8^{\mathrm{a}}$ & 0.99 & $0.5^{\mathrm{b}}$ & 0.14 & $0.2^{\mathrm{b}}$ & 0.08 & $0.1^{\mathrm{b}}$ & 0.06 \\
\hline$\%$ kreupele kalveren & 0.5 & 0.14 & 0.2 & 0.08 & 0.1 & 0.06 & 0.1 & 0.05 \\
\hline \% dikke knieën (verkregen slijmbeurs) & $2.6^{a}$ & 1.0 & $0.8^{\mathrm{b}}$ & 0.31 & $0.3^{\mathrm{b}}$ & 0.09 & $0.5^{\mathrm{b}}$ & 0.13 \\
\hline$\%$ aangebeten staart & 0.0 & 0.03 & 0.0 & 0.00 & 0.0 & 0.00 & 0.3 & 0.3 \\
\hline$\%$ urine drinkers & 0.1 & 0.05 & 0.0 & 0.02 & 0.3 & 0.20 & 0.05 & 0.04 \\
\hline$\%$ achterblijvers ( $15-30 \%$ achterstand in conditie) & $4.4^{a}$ & 0.52 & $4.0^{\mathrm{a}}$ & 0.55 & $4.0^{\mathrm{a}}$ & 0.70 & $2.4^{\mathrm{b}}$ & 0.47 \\
\hline$\%$ muiters ( $>30 \%$ achterstand in conditie) & 1.2 & 0.31 & 1.2 & 0.29 & 0.7 & 0.14 & 0.7 & 0.23 \\
\hline$\%$ natte kalveren & $1.7^{\mathrm{a}}$ & 0.71 & $2.5^{\mathrm{a}}$ & 0.71 & $1.6^{\mathrm{a}}$ & 0.56 & $0.3^{\mathrm{b}}$ & 0.14 \\
\hline
\end{tabular}




\begin{tabular}{|c|c|c|c|c|c|c|c|c|}
\hline \multirow{2}{*}{$\begin{array}{l}\text { Parameter } \\
\% \text { dorre kalveren }\end{array}$} & \multicolumn{2}{|c|}{ Ronde 1} & \multicolumn{2}{|c|}{ Ronde 2} & \multicolumn{2}{|c|}{ Ronde 3} & \multicolumn{2}{|c|}{ Ronde 4} \\
\hline & $4.9^{a}$ & 0.77 & $4.1^{\mathrm{a}}$ & 0.58 & $3.6^{\mathrm{a}}$ & 1.09 & $1.7^{\mathrm{b}}$ & 0.38 \\
\hline$\%$ bevuilde kalveren & $14.4^{\mathrm{a}}$ & 2.54 & $25.9^{\mathrm{b}}$ & 4.23 & $23.0^{\mathrm{b}}$ & 4.20 & $18.5^{\mathrm{a}, \mathrm{b}}$ & 3.12 \\
\hline$\%$ hokken met dunne mest & 4.9 & 2.22 & 6.1 & 1.60 & 7.2 & 2.20 & 8.3 & 1.77 \\
\hline$\%$ ernstig aangetaste longen & $33.8^{\mathrm{b}, \mathrm{c}}$ & 2.77 & $35.8^{c}$ & 2.77 & $28.3^{a, b}$ & 2.33 & $26.5^{\mathrm{a}}$ & 2.13 \\
\hline$\%$ longen met pleuritis & $74.4^{a}$ & 2.19 & $59.3^{\mathrm{b}}$ & 1.97 & $55.9^{b, c}$ & 2.31 & $50.7^{c}$ & 2.80 \\
\hline$\%$ penzen met plaques & $5.9^{a}$ & 1.51 & $18.7^{\mathrm{b}}$ & 4.57 & $25.5^{\mathrm{b}, \mathrm{c}}$ & 5.19 & $32.3^{c}$ & 6.02 \\
\hline Gemiddelde score pensontwikkeling van de koppel & 3.3 & 0.05 & 3.3 & 0.08 & 3.3 & 0.08 & 3.2 & 0.08 \\
\hline$\%$ lebmagen met lesies & 60.6 & 2.62 & 63.5 & 3.09 & 66.7 & 2.91 & 67.1 & 2.96 \\
\hline$\%$ uitval & $2.5^{a}$ & 0.44 & $3.0^{\mathrm{a}}$ & 0.39 & $3.9^{b}$ & 0.46 & $3.2^{\mathrm{a}, \mathrm{b}}$ & 0.46 \\
\hline
\end{tabular}

${ }^{1}$ Gem: gemiddelde

2SEM: Standard error of the mean, of standaardfout

${ }^{3}$ Een lebmaag met lesies is een lebmaag met één of meer lesies, los van de grootte

$\mathrm{a}, \mathrm{b}, \mathrm{c}$ Gemiddelden met verschillende letters verschillen significant van elkaar $(P<0.05$, tweezijdige toets, Fisher's LSD) 


\section{Bijlage 8 Overzicht van deeladviezen per onderdeel van de welzijnsmonitor}

\begin{tabular}{|c|c|c|}
\hline Onderdeel & $\begin{array}{c}\text { Aantal } \\
\text { deeladviezen }\end{array}$ & Soort advies \\
\hline Achterblijvers & 10 & $\begin{array}{l}\text { Apart zetten } \\
\text { Beter/routinematig sorteren } \\
\text { Deel melk vervangen door ruwvoer } \\
\text { Lichte kalveren } 3 x \text { per dag voeren } \\
\text { Meer ruwvoer en harder voeren bij de start } \\
\text { Rantsoen aanpassen en extra rosé brok } \\
\text { Extra behandelen }\end{array}$ \\
\hline Algemeen & 8 & $\begin{array}{l}\text { Bedrijfsbehandelplan voor start bespreken met dierenarts } \\
\text { Dextran bij spuiten } \\
\text { Lager ruwvoerniveau } \\
\text { Niet alle kalveren helpen te drinken } \\
\text { Niet te veel melk } \\
\text { Rust Reinheid en Regelmaat } \\
\text { Vaarzen inzetten }\end{array}$ \\
\hline Beenwerk & 2 & $\begin{array}{l}\text { Behandelen met micotil of nuflor } \\
\text { In apart hok zetten met stro en individueel met antibiotica behandelen }\end{array}$ \\
\hline Bevuiling kalf & 1 & Meer ruwvoer verstrekken \\
\hline Diarree & 11 & $\begin{array}{l}\text { Bij start } 3 x \text { per dag voeren } \\
\text { Digest plus voeren in de start } \\
\text { Eerder ruwvoer verstrekken } \\
\text { Meer ruwvoer en minder melkpoeder (ook beter haarkleed) } \\
\text { Meer vezel houdend voer } \\
\text { Melkdikte op max. } 125 \text { gram KMP per liter houden } \\
\text { Reinigen en ontsmetten na elke ronde } \\
\text { Stoppen met homeopathie } \\
\text { Veel aandacht nuka's en tijdig behandelen } \\
\text { Waterkwaliteit checken en aanpassen } \\
\text { Eerder muesli voeren }\end{array}$ \\
\hline Gedrag & 3 & $\begin{array}{l}\text { Meer stro voor meer herkauwers } \\
\text { Ruwvoer rustig omhoog om abnormaal oraal gedrag te verminderen } \\
\text { Vaker door de stallen lopen om angst te verminderen }\end{array}$ \\
\hline Gezondheid & 9 & $\begin{array}{l}\text { Opstarten met startvoer met magere melkpoeder } \\
\text { Eerder contact dierenarts } \\
\text { Langer in babybox } \\
\text { Proef met extra vitamine } \\
\text { Schurft behandelen en preventief werken } \\
\text { Stal vogeldicht maken } \\
\text { Stallen opstoken tot } 15 \text { graden bij start en } 3 x \text { daags voeren } \\
\text { Vitamine/mineralen voeren }\end{array}$ \\
\hline Gladheid vloer & 1 & Aanpassen/aandachtspunt \\
\hline$H B$ & 4 & $\begin{array}{l}\text { Extra dextran bij spuiten } \\
\text { Extra nakijken } \\
\text { Hoger aansturen op ijzer } \\
\text { Vaker checken }\end{array}$ \\
\hline Hygiëne & 4 & $\begin{array}{l}\text { Schone naald bij elk kalf } \\
\text { Water behandelen met dioclean }\end{array}$ \\
\hline Lesies lebmaag & 5 & $\begin{array}{l}\text { Beter sorteren en rantsoen aanpassen (voor bv voorlopers en mindere } \\
\text { kalveren) } \\
\text { Bij start onbeperkt ruwvoer en } 100 \text { gram per liter melk aanhouden } \\
\text { Meer structuur voeren } \\
\text { Tarwestro in plaats van koolzaadstro }\end{array}$ \\
\hline Longen & 82 & $\begin{array}{l}\text { Eerste } 8 \text { weken antibiotica in plaats van homeopathie (homeopathie als } \\
\text { extra toevoeging) } \\
\text { Antibiotica bespreken met dierenarts } \\
\text { Bedrijfsbehandelplan doornemen/beter volgen/ beoordelen }\end{array}$ \\
\hline
\end{tabular}




\begin{tabular}{|c|c|c|}
\hline Onderdeel & $\begin{array}{c}\text { Aantal } \\
\text { deeladviezen }\end{array}$ & Soort advies \\
\hline & & $\begin{array}{l}\text { Extra koppelkuur inzetten } \\
\text { Checken of individueel of koppelkuur nodig is } \\
\text { Eerder koppelkuur inzetten } \\
\text { Op tijd/beter/gerichter behandelen } \\
\text { Meer overleg dierenarts } \\
\text { Kuren afmaken } \\
\text { Bij start } 4 x \text { water met elektrolyten mix en bicarbonaat verstrekken } \\
\text { Broncharon bij start verstrekken } \\
\text { Doorgaan met de entingen en medicijnbeleid } \\
\text { Eerder GD inzetten } \\
\text { Enten Bodivast } \\
\text { In de startperiode meer aandacht schenken } \\
\text { Rustig voeren in start- en longenfase en meer ruwvoer } \\
\text { Long swaps om beter te reageren evt. Brocharom } \\
\text { Max. } 125 \text { gr/liter poedermelk hanteren bij de start } \\
\text { Mycoplasma beter bestrijden } \\
\text { Problemen proberen te verminderen } \\
\text { Ventilatie aandacht geven/ checken/doormeten/vernieuwen, } \\
\text { Ventilatie aanpassen (van } 1 \text { kant ventileren) } \\
\text { Beter/op de juiste manier ventileren } \\
\text { Klimaat optimaliseren (stoken) } \\
\text { Overstappen op mechanische ventilatie } \\
\text { Ventilatie aan weer aanpassen } \\
\text { Ventilatiekleppen aanpassen } \\
\text { Ventilatoren plaatsen } \\
\text { Windkappen plaatsen } \\
\text { Vit B-complex geven } \\
\text { Weerstand verhogen d.m.v. bijsturingsmiddelen } \\
\text { Weerstand verhogen door harder te voeren in de start }\end{array}$ \\
\hline Natte kalveren & 1 & Kalveren scheren \\
\hline Pens drinken & 5 & $\begin{array}{l}\text { Gelijkmatige melkgift } \\
\text { Pensdrinkers aan de speen } \\
\text { Stabiel rantsoen houden }\end{array}$ \\
\hline $\begin{array}{l}\text { Pens } \\
\text { ontwikkeling }\end{array}$ & 1 & Tarwestro in plaats van koolzaadstrro \\
\hline Pens verzuring & 12 & $\begin{array}{l}\text { Aantal stressmomenten verminderen } \\
\text { Meer en vaker aan het einde bicarbonaat voeren } \\
\text { Melkniveau verlagen } \\
\text { Natriumbicarbonaat/digestplus verstrekken } \\
\text { Snel ruwvoer verstrekken en mijdt contact melk- ruwvoer } \\
\text { Stro voeren en waterkwaliteit nakijken } \\
\text { Veiliger rantsoen in opfokstal } \\
\text { Voerschema laten checken } \\
\text { Water met ruwvoer verstrekken }\end{array}$ \\
\hline Plaques & 35 & $\begin{array}{l}\text { Aandachtspunt opstarten pens } \\
\text { Aanpassen ruwvoer } \\
\text { Bij opstarten pens, langzaam stro omhoog tot juiste hoeveelheid } \\
\text { Bij start onbeperkt ruwvoer en } 100 \text { gram per liter melk aanhouden } \\
\text { Bij start tarwestro i.p.v. koolzaadstro } \\
\text { Geen melkresten bij ruwvoer } \\
\text { Lager ruwvoer niveau en meer stro } \\
\text { Mais langer hakselen } \\
\text { Meer ruwvoer (hogere pH) } \\
\text { Meer stro voeren } \\
\text { Meer structuur voeren } \\
\text { Melk temperatuur checken en aanpassen } \\
\text { Min. } 10 \% \text { stro verstrekken (15\% in de startfase) } \\
\text { Na } 3 \text { weken kalveren los om ruwvoeropname te stimuleren en mogelijkheid } \\
\text { tot water geven } \\
\text { Natriumbicarbonaat door de melk } \\
\text { Onbeperkt ruwvoer } \\
\text { Rustig melkrantsoen } \\
\text { Ruwvoer op tijd starten en snel naar hoog niveau } \\
\text { Ruwvoer rustig omhoog } \\
\text { Stabiel rantsoen houden } \\
\text { Stro bijvoeren (nauwkeurig mengen/doseren) } \\
\text { Temperatuurinstellingen voer nalopen } \\
\text { Voer checken }\end{array}$ \\
\hline Uitval & 3 & Andere melkpoeder en meer ruwvoer voeren \\
\hline
\end{tabular}




\begin{tabular}{|c|c|c|}
\hline Onderdeel & $\begin{array}{c}\text { Aantal } \\
\text { deeladviezen }\end{array}$ & Soort advies \\
\hline & & $\begin{array}{l}\text { Natriumbicarbonaat/digestplus verstrekken } \\
\text { Sorteren en extra behandelen }\end{array}$ \\
\hline Urine drinken & 2 & $\begin{array}{l}\text { Check of loslaten al kan } \\
\text { Ruwvoer op tijd starten en snel naar hoog niveau }\end{array}$ \\
\hline Vertering & 9 & $\begin{array}{l}\text { Drie keer per dag voeren met Allium en Norit door de melk } \\
\text { Eerder ruwvoer en hoger niveau } \\
\text { In de startperiode meer aandacht schenken } \\
\text { Niet te veel melk verstrekken bij start } \\
\text { Preparaten toevoegen } \\
\text { Snel verstrekken van ruwvoer bij de start } \\
\text { Voercheck uitvoeren } \\
\text { Voldoende structuur houdend materiaal (stro) in het rantsoen houden }\end{array}$ \\
\hline $\begin{array}{l}\text { Vertering } \\
\text { (laesies } \\
\text { lebmaag en } \\
\text { plaques) }\end{array}$ & 10 & $\begin{array}{l}\text { Bicarbonaat door melk verstrekken } \\
\text { Bij stressmomenten aspirine voeren en voldoende stro geven } \\
\text { Geen mais voeren } \\
\text { Meer ruwvoer en minder melkpoeder } \\
\text { Meer stro en calcium carbonaat verstrekken } \\
\text { Meer/ eerder stro verstrekken } \\
\text { Minder stro voeren ( } 10-20 \%) \\
\text { Na loslaten beginnen met water verstrekken na ruwvoer } \\
\text { Ruwvoer op tijd starten en percentage stro omhoog bij loslaten } \\
\text { Water later verstrekken } \\
\text { Voersamenstelling aanpassen }\end{array}$ \\
\hline Water & 4 & $\begin{array}{l}\text { Meer/onbeperkt water verstrekken } \\
\text { Offerte aanvragen voor drinknippels }\end{array}$ \\
\hline
\end{tabular}




\section{Bijlage 9 Overzicht aanpassingen door kalverhouder}

\begin{tabular}{|c|c|c|}
\hline Onderdeel & $\begin{array}{c}\text { Aantal } \\
\text { aanpassingen }\end{array}$ & Soort aanpassing \\
\hline $\begin{array}{l}\text { Aanpassing } \\
\text { rantsoen }\end{array}$ & 43 & $\begin{array}{l}\text { 1x/dag melk en veel ruwvoer } \\
\text { Onbeperkt brok en stro } \\
3 \% \text { meer melk en } 3 \% \text { minder wei } \\
\text { Nattere mais qua droge stof en zetmeel mais } \\
\text { Meer brok } \\
\text { Meer ruwvoer } \\
\text { Drogere mais + vit c } \\
\text { Meer muesli en minder melk } \\
\text { Half mm poeder/half nul product } \\
\text { Hoger droge stof gehalte } \\
\text { Onbeperkt ruwvoer } \\
\text { Minder bijproducten } \\
\text { Natrium bicarbonaat bij. andere mais i.v.m. zetmeel } \\
\text { Opstart vloeibare melk en meer gerst } \\
\text { Opstart met magere melkpoeder } 15 \% \\
\text { Stro verdeling over mestperiode is anders } \\
\text { Langer doorvoeren, betere dosering voer) }\end{array}$ \\
\hline Achterblijvers & 1 & Mindere kalveren op stro \\
\hline Enten & 6 & $\begin{array}{l}\text { Nieuwe enting } \\
\text { Bovipast } \\
\text { Pinkengriep }\end{array}$ \\
\hline$H B$ & 3 & $\begin{array}{l}\text { IJzer bij spuiten } \\
2 \text { weken prikken }\end{array}$ \\
\hline Homeopathie & 1 & Kastanje poeder verstrekt \\
\hline Hygiëne & 3 & Extra schoongemaakt en ontsmet \\
\hline Kalveren & 3 & $\begin{array}{l}\text { Alleen stieren } \\
\text { Italiaanse kalveren } \\
\text { Lichtere kalveren } \\
\text { Zwaardere kalveren }\end{array}$ \\
\hline Koppelkuur & 2 & $\begin{array}{l}\text { Extra koppelkuur } \\
\text { Sneller koppelkuur inzetten }\end{array}$ \\
\hline Management & 5 & $\begin{array}{l}\text { Naar } 1 \text { leeftijd over gegaan } \\
\text { Andere dierenarts } \\
\text { Andere voerleverancier } \\
\text { Andere vertegenwoordiger } \\
\text { Meer aandacht geschonken door veehouder/ dierenarts aan } \\
\text { longen } \\
\text { Eerder medicatie toepassen } \\
\text { Vaker sorteren }\end{array}$ \\
\hline Melkpoeder & 9 & Ander melkpoeder \\
\hline Ruwvoer & 14 & $\begin{array}{l}\text { Gestopt met mais } \\
\text { Feedmix voeren voor smakelijk hogere voeropname } \\
\text { Graanborstel bijvoeren (ipv corngold) } \\
\text { Grof mais } \\
\text { Geplette tarwe } \\
\text { Luzerne bij opstart } \\
\text { Voergang verhoogd betere voeropname } \\
\text { Tarwestro ipv koolzaadstro } \\
\text { Alles op ruwvoerbakken }\end{array}$ \\
\hline Ventilatie & 17 & $\begin{array}{l}\text { Andere luchtinlaat } \\
\text { Meer ventilatie } \\
\text { Kappen geplaatst } \\
\text { Grotere ventilatoren geplaatst } \\
\text { Ramen boven de hokken dicht en ramen aan de voergangzijde } \\
\text { op kiepstand open } \\
\text { Roldeur ventilatie }\end{array}$ \\
\hline
\end{tabular}




\begin{tabular}{|c|c|c|}
\hline Onderdeel & $\begin{array}{c}\text { Aantal } \\
\text { aanpassingen }\end{array}$ & Soort aanpassing \\
\hline & & $\begin{array}{l}\text { Ruimte onder de trog afgesloten zodat er geen lucht onder de } \\
\text { roosters doortrekt } \\
\text { Mechanisch ventileren (i.p.v. natuurlijk ventilatie)) }\end{array}$ \\
\hline Water & 4 & $\begin{array}{l}\text { Kwaliteit verbeterd } \\
\text { Nieuwe drinknippels } \\
\text { 's Nachts water verstrekken } \\
\text { Geen water }\end{array}$ \\
\hline
\end{tabular}




\section{Bijlage 10 Effect van gegeven adviezen}

Effect van de gegeven adviezen op uitkomsten welzijnsmonitor tijdens de daarop volgende ronde op de 6 bedrijven (A t/m F)

\begin{tabular}{|c|c|c|c|c|c|}
\hline Bedrijf & $\begin{array}{l}\text { Advies } \\
\text { na ronde }\end{array}$ & $\begin{array}{l}\text { Deeladvies en maatregelen op het } \\
\text { gebied van: }\end{array}$ & Effect op uitkomsten volgende ronde & Andere positieve effecten & $\begin{array}{l}\text { Andere negatieve } \\
\text { effecten }\end{array}$ \\
\hline \multirow[t]{3}{*}{$\mathbf{A}$} & 1 & $\begin{array}{l}\text { 1) Plaques: melkgift gelijkmatig en zo } \\
\text { snel mogelijk ruwvoergift. } \\
\text { 2) Longen: frequenter bezoek veearts }\end{array}$ & $\begin{array}{l}\text { 1) Geen; \% plaques in de pens verhoogd } \\
\text { 2) Hoger \% ernstig aangetaste longen; } \\
\% \text { pleuritis verlaagd }\end{array}$ & $\begin{array}{l}\text { Lager \% verkregen slijmbeurs, } \\
\text { hoesten, neusuitvloeiing, } \\
\text { achterstand conditie en } \\
\text { abnormaal oraal gedrag. }\end{array}$ & $\begin{array}{l}\text { Hoger \% dunne mest, volle } \\
\text { en natte kalveren }\end{array}$ \\
\hline & 2 & Longen: eerder veearts inschakelen & Geen & $\begin{array}{l}\text { Lager \% kreupele kalveren, } \\
\text { verkregen slijmbeurs, afwijkende } \\
\text { ademhaling, neusuitvloeiing, volle } \\
\text { en natte kalveren, abnormaal } \\
\text { oraal gedrag en urine drinken. }\end{array}$ & $\begin{array}{l}\text { Hoger \% lesies in de } \\
\text { lebmaag en minder kalveren } \\
\text { aangeraakt in de Calf } \\
\text { Escape Test (CET). }\end{array}$ \\
\hline & 3 & $\begin{array}{l}\text { Vertering/Plaques: voerprocedure } \\
\text { doorgesproken en dagelijks opvoeren } \\
\text { van het ruwvoer }\end{array}$ & $\begin{array}{l}\text { Lager } \% \text { dunne mest en lesies in de } \\
\text { lebmaag; hoger } \% \text { plaques in de pens }\end{array}$ & $\begin{array}{l}\text { Lager } \% \text { aangetaste longen, } \\
\text { kalveren met achterstand in } \\
\text { conditie en kalveren die } \\
\text { abnormaal oraal gedrag vertonen. }\end{array}$ & \\
\hline \multirow[t]{3}{*}{ B } & $\mathbf{1}$ & $\begin{array}{l}\text { 1) Longen: ventilatie check } \\
\text { 2) Algehele gezondheid: } \\
\text { bedrijfsbehandelplan met veearts } \\
\text { doorlopen }\end{array}$ & $\begin{array}{l}\text { 1) Lager \% ernstig beschadigde longen } \\
\text { 2) Lager \% kreupel, afwijkende } \\
\text { ademhaling, dunne mest, dorre kalveren } \\
\text { en urine drinken }\end{array}$ & & $\begin{array}{l}\text { Hoger \% hoesten, } \\
\text { neusuitvloeiing, zieke en } \\
\text { natte kalveren. }\end{array}$ \\
\hline & 2 & $\begin{array}{l}\text { 1) Plaques: voercheck } \\
\text { 2) Longen: ventilatie check }\end{array}$ & $\begin{array}{l}\text { 1) Lichte daling van \% plaques } \\
\text { 2) Lager \% hoesten, afwijkende } \\
\text { ademhaling en longbeschadigingen }\end{array}$ & $\begin{array}{l}\text { Lager \% neusuitvloeiing en lesies } \\
\text { in de lebmaag }\end{array}$ & $\begin{array}{l}\text { Iets hoger \% dunne mest, } \\
\text { en uitval }\end{array}$ \\
\hline & 3 & $\begin{array}{l}\text { 1) Vertering: temperatuurinstelling } \\
\text { melk nagelopen } \\
\text { 2) Longen: ventilatie check }\end{array}$ & $\begin{array}{l}\text { 1) Lager \% dunne mest; hoger \% lesies } \\
\text { in de lebmaag en plaques in de pens. } \\
2 \text { ) Minder \% longen aangetast; hoger \% } \\
\text { afwijkende ademhaling }\end{array}$ & $\begin{array}{l}\text { Lager \% uitval } \\
\text { Hoger \% kalveren aangeraakt in } \\
\text { de CET }\end{array}$ & $\begin{array}{l}\text { Hoger \% verkregen } \\
\text { slijmbeurs, dorre en zieke } \\
\text { kalveren }\end{array}$ \\
\hline \multirow[t]{2}{*}{ C } & 1 & $\begin{array}{l}\text { Vertering (lesies lebmaag een } \\
\text { plaques): in start/longenfase rustiger } \\
\text { melk voeren, minder stro verstrekken } \\
(10-20 \%) \text { en na loslaten water } \\
\text { verstrekken na ruwvoer }\end{array}$ & Iets lager \% lesies in de lebmaag & $\begin{array}{l}\text { Lager \% volle kalveren en } \\
\text { abnormaal oraal gedrag. }\end{array}$ & $\begin{array}{l}\text { Hoger } \% \text { plaques in de pens, } \\
\text { afwijkende ademhaling, } \\
\text { aangetaste longen, dorre en } \\
\text { natte kalveren }\end{array}$ \\
\hline & 2 & $\begin{array}{l}\text { 1) Vertering (lesies lebmaag een } \\
\text { plaques): strikter protocol volgen mbt } \\
\text { melkgift in de start }\end{array}$ & $\begin{array}{l}\text { 1) Lager \% abnormaal oraal gedrag, iets } \\
\text { lager \% plaques in de pens en } \% \text { lesies } \\
\text { in de lebmaag verhoogd }\end{array}$ & $\begin{array}{l}\text { Lager \% kreupele kalveren, } \\
\text { dunne mest, natte kalveren. }\end{array}$ & \\
\hline
\end{tabular}




\begin{tabular}{|c|c|c|c|c|c|}
\hline Bedrijf & $\begin{array}{l}\text { Advies } \\
\text { na ronde }\end{array}$ & $\begin{array}{l}\text { Deeladvies en maatregelen op het } \\
\text { gebied van: }\end{array}$ & Effect op uitkomsten volgende ronde & Andere positieve effecten & $\begin{array}{l}\text { Andere negatieve } \\
\text { effecten }\end{array}$ \\
\hline & & $\begin{array}{l}\text { 2) Longen: bedrijfsbehandelplan met } \\
\text { veearts doorlopen }\end{array}$ & $\begin{array}{l}\text { 2) Iets lager } \% \text { afwijkende ademhaling } \\
\text { en neusuitvloeiing, maar hoger } \% \\
\text { ernstig aangetaste longen }\end{array}$ & & \\
\hline & 3 & $\begin{array}{l}\text { 1) Vertering (lesies lebmaag en plaques } \\
\text { in de pens): eerder kalveren met } \\
\text { diarree behandelen; strikter voeren en } \\
\text { vroeg starten met startmuesli } \\
\text { 2) Longen: eerder contact met veearts } \\
\text { in de startperiode }\end{array}$ & $\begin{array}{l}\text { 1) Lager \% dunne mest en volle } \\
\text { kalveren, maar hoger \% plaques in de } \\
\text { pens } \\
\text { 2) Lager \% aangetaste longen, hoesten, } \\
\text { afwijkende ademhaling en } \\
\text { neusuitvloeiing }\end{array}$ & $\begin{array}{l}\text { Lager \% kreupele kalveren, dorre } \\
\text { kalveren, zieke kalveren, } \\
\text { kalveren met achterstand in } \\
\text { conditie en urine drinkers. }\end{array}$ & Hoger \% natte kalveren \\
\hline \multirow[t]{3}{*}{ D } & $\mathbf{1}$ & $\begin{array}{l}\text { 1) Watervoorziening: langere periode } \\
\text { per dag water verstrekken } \\
\text { 2) Longen: aandacht ventilatie en } \\
\text { klimaat } \\
\text { 3) Vertering (plaques en lesies } \\
\text { lebmaag): eerder ruwvoer en hoog } \\
\text { niveau }\end{array}$ & $\begin{array}{l}\text { 1) Betere score watervoorziening } \\
\text { 2) Lager percentage aangetaste longen } \\
\text { 3) Lager \% dunne mest, plaques in de } \\
\text { pens, volle kalveren. Geen effect op } \\
\text { lesies in de lebmaag }\end{array}$ & $\begin{array}{l}\text { Lager } \% \text { achterstand conditie } 15- \\
30 \% \text {, bevuilde kalveren en } \\
\text { abnormaal oraal gedrag }\end{array}$ & Hoger \% natte kalveren \\
\hline & 2 & $\begin{array}{l}\text { 1) Longen: ventilatie checken } \\
\text { 2) Plaques: langzaam hoeveelheid stro } \\
\text { omhoog }\end{array}$ & $\begin{array}{l}\text { 1) Lager } \% \text { hoesten, maar hoger } \% \\
\text { aangetaste longen. } \\
\text { 2) Hoger } \% \text { plaques in de pens }\end{array}$ & $\begin{array}{l}\text { Lager \% verkregen slijmbeurs, } \\
\text { afwijkende ademhaling, uitval en } \\
\text { natte kalveren }\end{array}$ & $\begin{array}{l}\text { Hoger } \% \text { volle kalveren, } \\
\text { dorre kalveren, zieke } \\
\text { kalveren, kalveren met laag } \\
\text { HB, kalveren met } \\
\text { achterstand conditie }>30 \% \\
\text { en urine drinkers } \\
\text { Lager \% kalveren } \\
\text { aangeraakt in de CET }\end{array}$ \\
\hline & 3 & $\begin{array}{l}\text { 1) Longen: meer aandacht klimaat bij } \\
\text { kleine kalveren } \\
\text { 2) } \mathrm{HB} \text { : hoger aansturen met ijzer bij de } \\
\text { opstart }\end{array}$ & $\begin{array}{l}\text { 1) Lager \% afwijkende ademhaling, } \\
\text { neusuitvloeiing en ernstig aangetaste } \\
\text { longen } \\
\text { 2) Lager \% kalveren met een laag HB }\end{array}$ & $\begin{array}{l}\text { Lager } \% \text { volle kalveren, dorre } \\
\text { kalveren, natte kalveren en } \\
\text { achterstand conditie } 15-30 \%\end{array}$ & $\begin{array}{l}\text { Hoger \% kalveren } \\
\text { achterstand conditie }>30 \% \text {, } \\
\text { uitval, abnormaal oraal } \\
\text { gedrag en urine drinken. }\end{array}$ \\
\hline \multirow[t]{2}{*}{$\mathbf{E}$} & 1 & $\begin{array}{l}\text { 1) Longen: windkappen plaatsen } \\
\text { 2) Vertering: voer check } \\
\text { 3) Achterblijvers: in aparte afdeling }\end{array}$ & $\begin{array}{l}\text { 1) Lager \% kalveren met afwijkende } \\
\text { ademhaling, neusuitvloeiing, ernstig } \\
\text { aangetaste longen } \\
\text { 2) Lager \% dunne mest, betere pens } \\
\text { ontwikkeling } \\
\text { 3) Lager \% kalveren met achterstand } \\
\text { conditie }\end{array}$ & $\begin{array}{l}\text { Lager \% kreupele kalveren, } \\
\text { verkregen slijmbeurs, dorre } \\
\text { kalveren, kalveren met laag HB, } \\
\text { urine drinkers }\end{array}$ & $\begin{array}{l}\text { Hoger \% lesies in de } \\
\text { lebmaag en abnormaal oraa } \\
\text { gedrag. } \\
\text { Lager \% kalveren } \\
\text { aangeraakt in de CET. }\end{array}$ \\
\hline & 2 & $\begin{array}{l}\text { 1) Vertering: voercheck } \\
\text { 2) Longen: ventilatie kleppen } \\
\text { aanpassen }\end{array}$ & $\begin{array}{l}\text { 1) Geen effect } \\
\text { 2) Lager } \% \text { hoesten en aangetaste } \\
\text { longen, hoger } \% \text { afwijkende ademhaling }\end{array}$ & $\begin{array}{l}\text { Lager } \% \text { zieke kalveren en } \\
\text { abnormaal oraal gedrag } \\
\text { Hoger \% kalveren aangeraakt in } \\
\text { de CET. }\end{array}$ & $\begin{array}{l}\text { Hoger \% verkregen } \\
\text { slijmbeurs, dorre kalveren, } \\
\text { achterstand conditie }>30 \% \text {, } \\
\text { urine drinkers. }\end{array}$ \\
\hline
\end{tabular}




\begin{tabular}{|c|c|c|c|c|c|}
\hline Bedrijf & $\begin{array}{l}\text { Advies } \\
\text { na ronde }\end{array}$ & $\begin{array}{l}\text { Deeladvies en maatregelen op het } \\
\text { gebied van: }\end{array}$ & Effect op uitkomsten volgende ronde & Andere positieve effecten & $\begin{array}{l}\text { Andere negatieve } \\
\text { effecten }\end{array}$ \\
\hline & 3 & $\begin{array}{l}\text { Longen: meer ventilatie op } \\
\text { ruwvoerbakken }\end{array}$ & Geen; hoger \% hoesten & $\begin{array}{l}\text { Lager \% kreupele kalveren, } \\
\text { verkregen slijmbeurs, dorre } \\
\text { kalveren en kalveren met } \\
\text { achterstand conditie. }\end{array}$ & $\begin{array}{l}\text { Hoger \% dunne mest en } \\
\text { natte kalveren } \\
\text { Pens is minder goed } \\
\text { ontwikkeld. } \\
\text { Lager \% kalveren } \\
\text { aangeraakt in de CET. }\end{array}$ \\
\hline \multirow[t]{3}{*}{$\mathbf{F}$} & 1 & Longen: antibiotica ipv homeopathie & $\begin{array}{l}\text { Geen effect; hoger \% hoesten en } \\
\text { afwijkende ademhaling }\end{array}$ & $\begin{array}{l}\text { Lager \% kreupele kalveren, } \\
\text { verkregen slijmbeurs, aangebeten } \\
\text { staart/oor, plaques in de pens, } \\
\text { kalveren met laag HB, abnormaal } \\
\text { oraal gedrag }\end{array}$ & $\begin{array}{l}\text { Hoger \% neusuitvloeiing, } \\
\text { lesies in de lebmaag en volle } \\
\text { kalveren } \\
\text { Lager \% kalveren } \\
\text { aangeraakt in de CET }\end{array}$ \\
\hline & 2 & $\begin{array}{l}\text { 1) Longen: meer aandacht in de start } \\
\text { en eerder behandelen } \\
\text { 2) Vertering: } 3 x \text { daags voeren en } \\
\text { eerder aanpak diarree }\end{array}$ & $\begin{array}{l}\text { 1) Lager \% hoesten, afwijkende } \\
\text { ademhaling en neusuitvloeiing } \\
\text { 2) Geen; hoger \% dunne mest, plaques } \\
\text { in de pens }\end{array}$ & $\begin{array}{l}\text { Lager \% zieke kalveren, } \\
\text { achterstand conditie } 15-30 \% \\
\text { Hoger \% kalveren aangeraakt in } \\
\text { de CET. }\end{array}$ & $\begin{array}{l}\text { Hoger \% lesies in de } \\
\text { lebmaag, kalveren met laag } \\
\text { HB en urine drinkers }\end{array}$ \\
\hline & 3 & $\begin{array}{l}\text { 1) } \mathrm{HB}: \text { bij start ijzer bijspuiten } \\
\text { 2) Vertering (plaques en lesies } \\
\text { lebmaag): muesli en stro voeren ipv } \\
\text { mais. }\end{array}$ & $\begin{array}{l}\text { 1) Lager } \% \text { kalveren met laag HB } \\
\text { 2) Iets minder plaques in de pens, lager } \\
\% \text { volle kalveren }\end{array}$ & $\begin{array}{l}\text { Lager } \% \text { afwijkende ademhaling, } \\
\text { ernstig beschadigde longen, } \\
\text { uitval, achterstand conditie } \\
>30 \% \text {, natte kalveren en urine } \\
\text { drinkers. }\end{array}$ & \\
\hline
\end{tabular}




\section{Bijlage 11 Nieuwsbrief welzijnsmonitor}

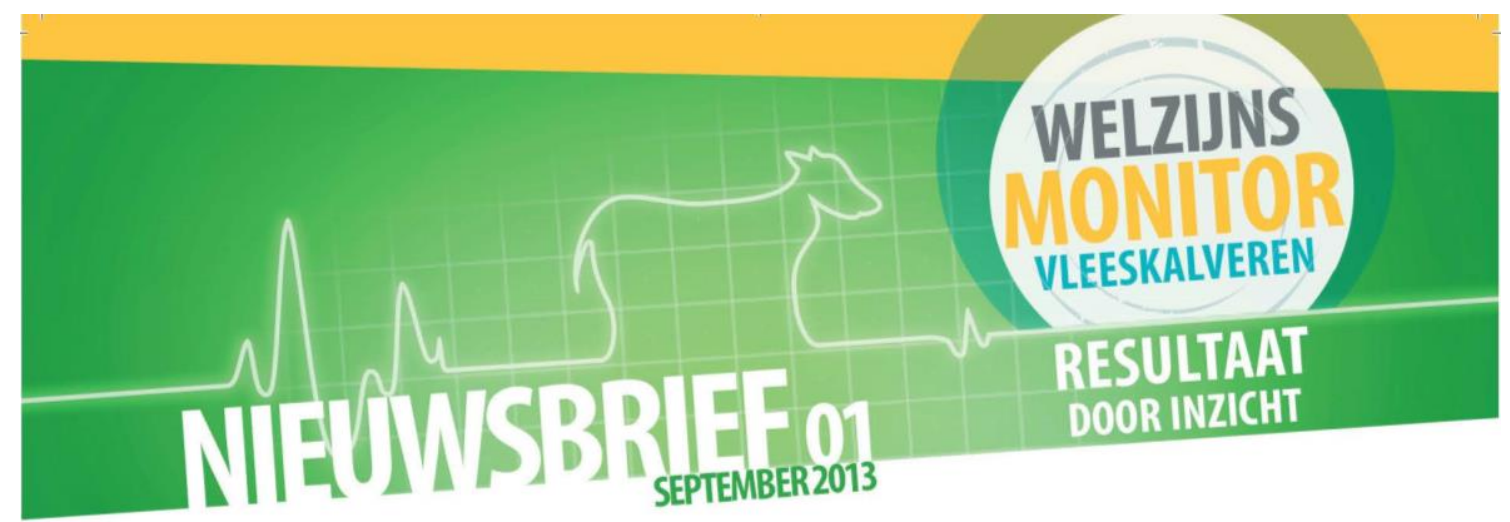

\section{Voortgang welzijnsmonitor via nieuwsbrief}

Onderzoekers van Wageningen UR willen kalverhouders tweemaal per jaar op de hoogte houden van de voortgang van het project Welzijnsmonitor Vleeskalveren. De gedrukte nieuwsbrief die u nu voor u heeft, wordt eenmalig uitgegeven. Alle volgende nieuwsbrieven verschijnen digitaal via de e-mail. Hoe u zich hiervoor kunt aanmelden staat op de achterpagina. Met de nieuwsbrief blijtt u niet alleen op de hoogte van nieuws en ontwikkelingen rondom de welzijnsmonitor, ook worden er filmpjes gemaakt die op de site van De Kalverhouder (www.dekalverhouder.nl) getoond worden. De nieuwsbrief wordt uitgegeven door Stichting Kwaliteitsgarantie Vleeskalversector (SKV) en Wageningen UR, in samenwerking met Hogeschool Van Hall Larenstein en Vakblad de Kalverhouder.

\section{Verbeteren \\ bedrijfsvoering}

De afgelopen jaren is voor de vleeskalverhouderij een Welzijnsmonitor ontwikkeld. Met deze monitor wordt op een gestructureerde wijze naar de gezondheid en het gedrag van de kalveren gekeken, evenals naar de directe omgeving.

De informatie uit de Welzijnsmonitor kan kalverhouders helpen bij het verbeteren van hun bedriffvoering. Bovendien levert het voor integraties een extra kwaliteitsborging op, waarmee zij naar retail en consument kunnen communiceren.

In het voorjaar van 2013 is een driejarig project gestart om deze Welzijnsmonitor verder te ontwikkelen en praktijkrijp te maken. Op dit moment doen 52 kalverhouders aan het project mee. Ervaringen van deelnemende kalverhouders en direct betrokkenen zal via deze nieuwsbrief (en de digitale nieuwsbrieven die volgen) met u gedeeld worden.

\section{Verbeteren \\ bedrijfsvoering}

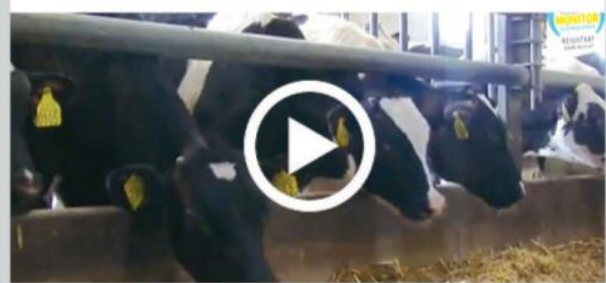

Hoe wordt er gemeten aan het kalf in de stal en in het slachthuis? Patrick van Til van SKV legt in een filmpje uit hoe de metingen in zijn werk gaan.

Het filmpje is te zien op www.dekalverhouder.nl onder de knop foto/film. De welzijnsmonitor werkt met waarnemingen en metingen aan de kalveren en hun directe omgeving. De waarnemingen zijn op te splitsen in drie categorieën: de gezondheid van de kalveren, het gedrag van de kalveren en een onderzoek in het slachthuis. De resultaten kunnen vergeleken worden met die van andere bedrijven. De vervolgstappen - analyseren, adviseren en treffen van maatregelen - worden in komende nieuwsbrieven nader toegelicht. 


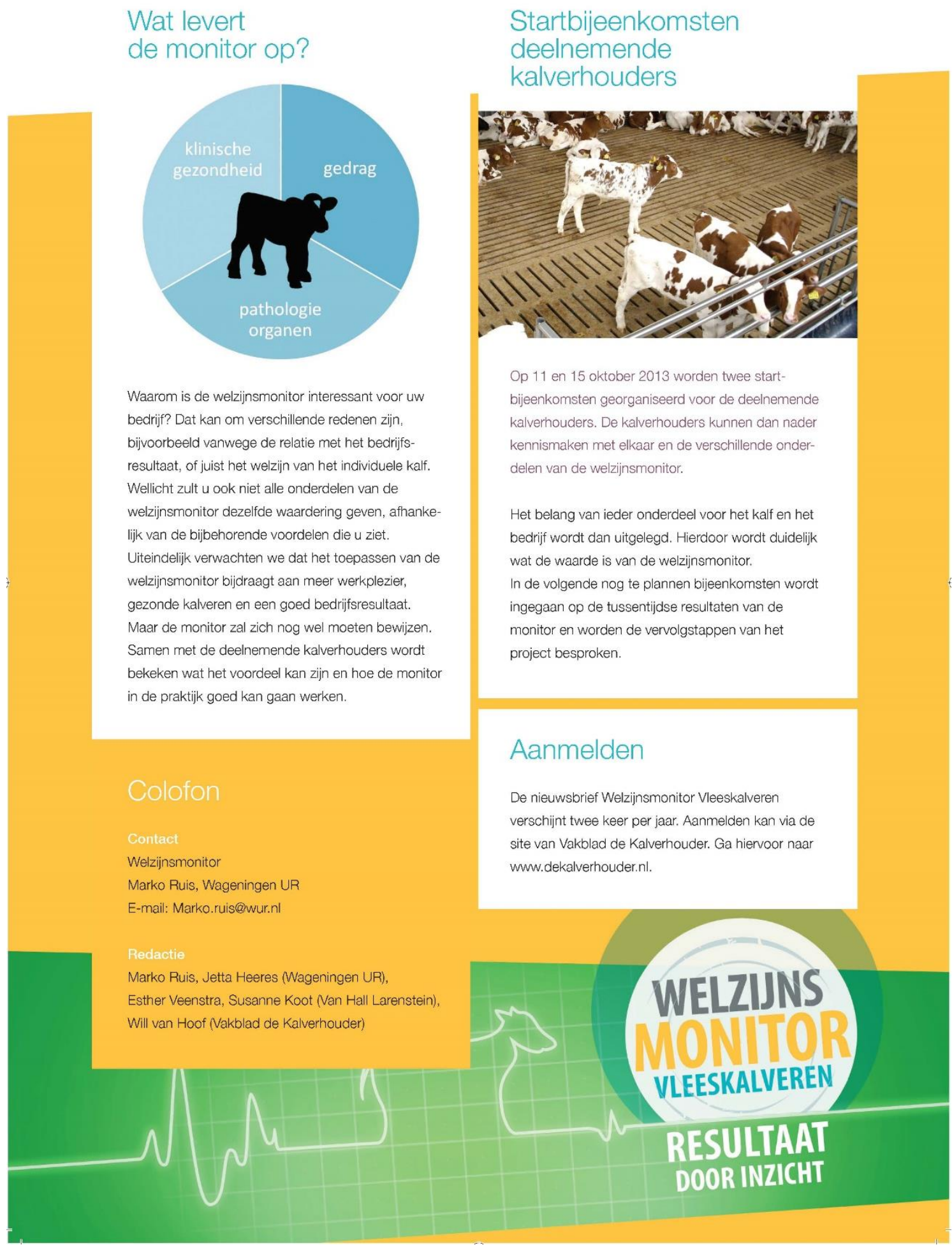




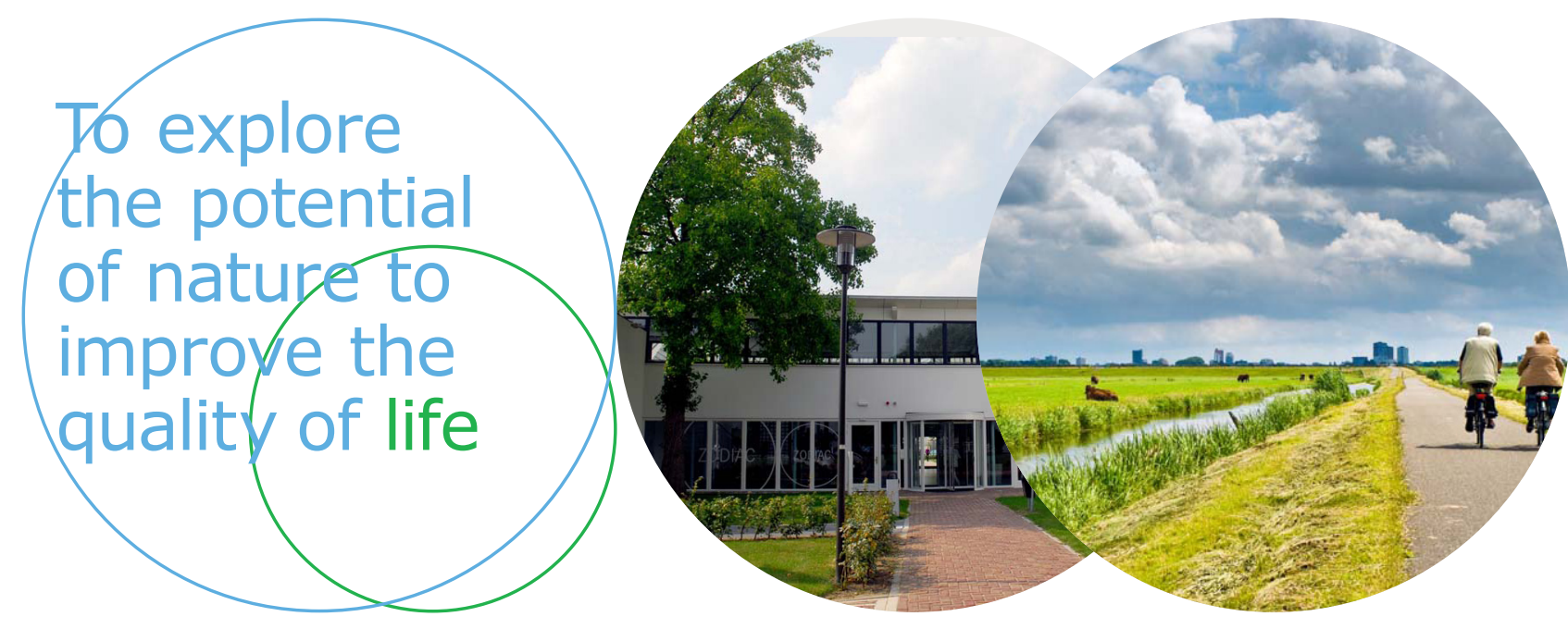

Wageningen Livestock Research Postbus 338

$6700 \mathrm{AH}$ Wageningen

T 0317483953

E info.livestockresearch@wur.nl www.wur.nl/livestock-research
Wageningen Livestock Research ontwikkelt kennis voor een zorgvuldige en renderende veehouderij, vertaalt deze naar praktijkgerichte oplossingen en innovaties, en zorgt voor doorstroming van deze kennis. Onze wetenschappelijke kennis op het gebied van veehouderijsystemen en van voeding, genetica, welzijn en milieu-impact van landbouwhuisdieren integreren we, samen met onze klanten, tot veehouderijconcepten voor de $21 \mathrm{e}$ eeuw.

De missie van Wageningen University \& Research is 'To explore the potential of nature to improve the quality of life'. Binnen Wageningen University \& Research bundelen 9 gespecialiseerde onderzoeksinstituten van Stichting Wageningen Research en Wageningen University hun krachten om bij te dragen aan de oplossing van belangrijke vragen in het domein van gezonde voeding en leefomgeving. Met ongeveer 30 vestigingen, 6.500 medewerkers en 10.000 studenten behoort Wageningen University \& Research wereldwijd tot de aansprekende kennisinstellingen binnen haar domein. De integrale benadering van de vraagstukken en de samenwerking tussen verschillende disciplines vormen het hart van de unieke Wageningen aanpak. 